\title{
برنامج دراما إبداعية لتنمية الوعي بالأمن القومي لأطفال الروضة
}

إعداد د/ نورهان تحمد بهجث أنور

مقدمة

يعـد الأمـن الآن مطلبـاً ضـرورياً للـدول و المجتمعـات فـي ظـلـل التحـديات الإقتصـادية و السياسـية و الإجتماعية و العسكرية و البيئة التي تو اجهها وتفرض عليها توفير الآمان و الإطمئنان لمو اطنيها الذي هو

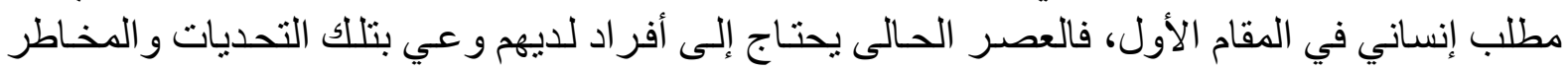

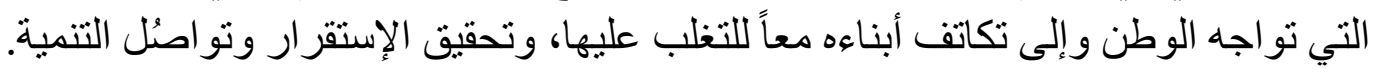

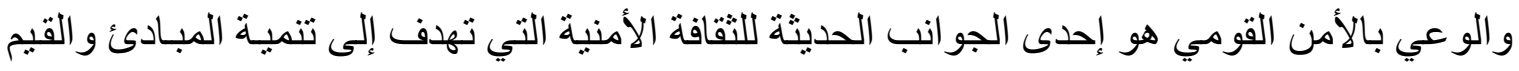
المتعلقة بالوطن للمتعلمين و التي تساعدهم على تشكيل عقو لهم ووجدانهم منذ الصغر لمعرفة معنى الوطن

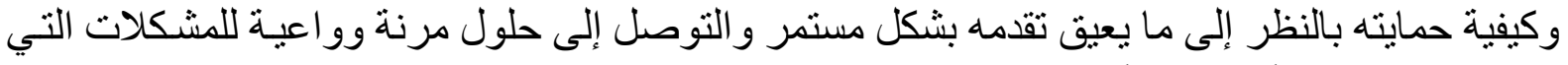

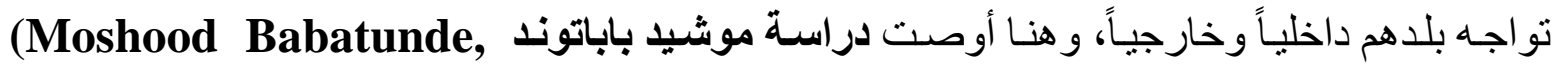

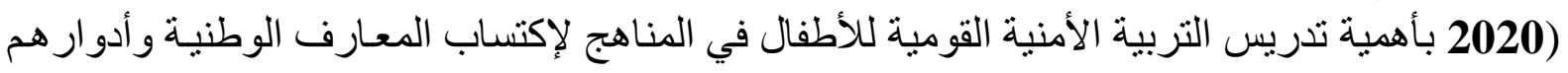

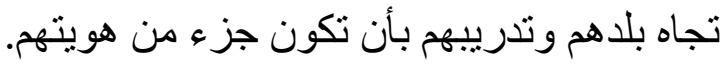

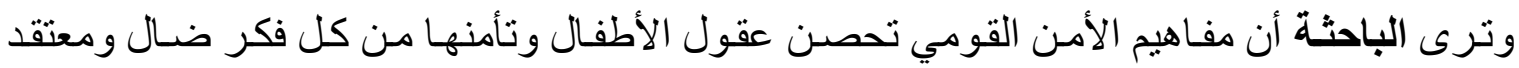

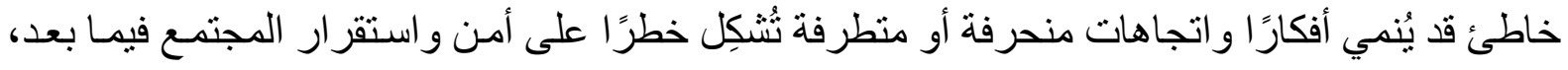

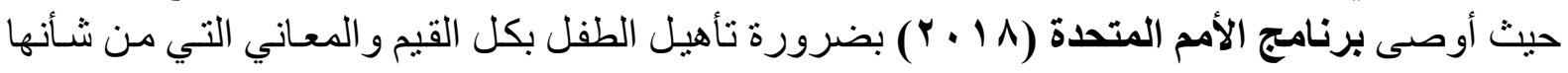
تمنع إستخلاله ضد وطنه (NSP,2017-2022: 10).

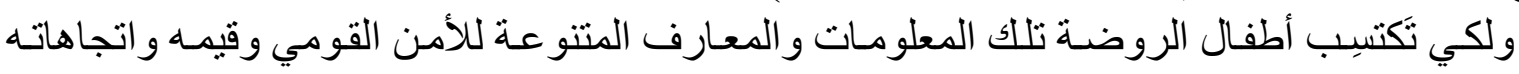
الإيجابية و أدوار كل أفراد المجتمع لتحقيقه، يحتاجون إلى ممارستها في شكل جمـاعي حر مـع أقر انهم

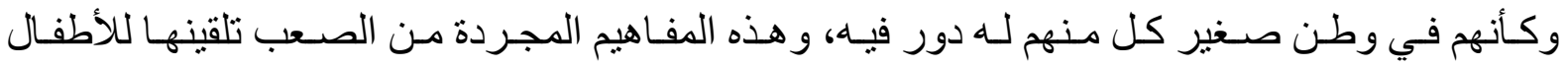
بالأساليب المباشرة ولكن من خلال تمثيلها ومعايشتها، و هذا ما توفره الدر اما الإبداعية.

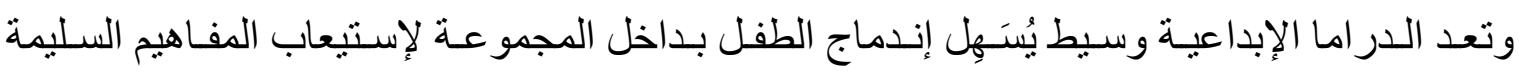
و إستبعاد المشو هة منها، وذللك يتم بشكل تلقائي من خـلال إعتمادهـا على التمثيل الحر و والإبـداع و والخيال

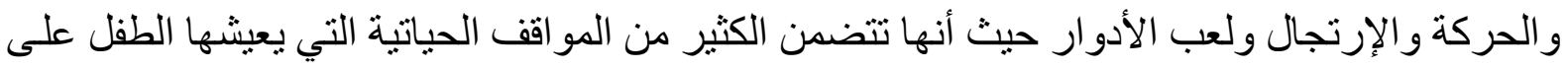

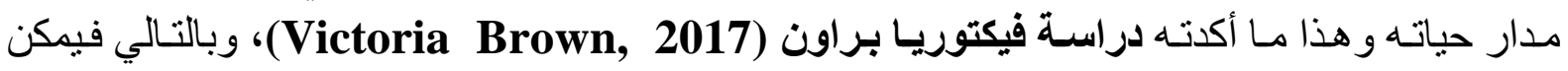
تُوظيفها بشكل فعال لتحقيق أهداف محددة.

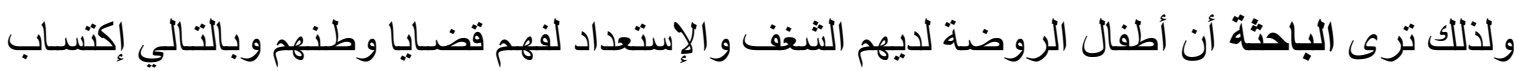
مفاهيم الأمن القومي، ممـا يسـاهم في إستيعاب معنى الوطن ونقاط قوتـه و المخـاطر التي تهدده وتكوين

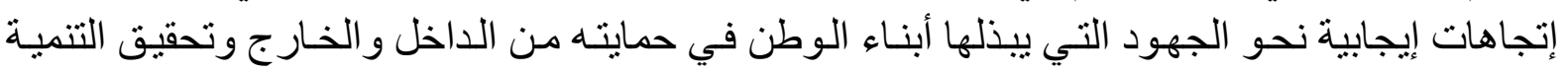

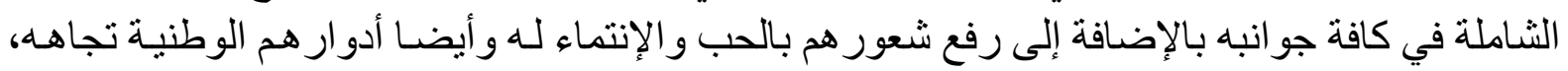
وبالتالي إعتمد البحث على إعداد أنشطة در اما إبداعية لمناسبتها لإكتساب أطفال الروضة فلثة تلك المفاهيم في جو حر تلقائي من خلال مشاركتهم معاً في تمثيل مو اقف إجتماعية متنو عة من بيئتهم.

* د. نور هان محمد بهجت أنور : مدرس بقسم العلوم الأساسية ـ كلية التربية للطفولة المبكرة - جامعة القاهرة. 
مشكلة البحث:

لقد بـدأ الإحسـاس بمشكلة البحث من خـلال الخبرة العمليـة وملاحظة الأطفـال أثنـاء الأشـر اف علي

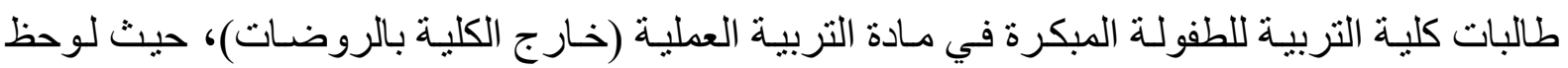
قصور منهج الأطفال علي تناول مفاهيم الوعي بالأمن القومي بداخل أنشطة البرنامج اليومي منثل (أهميـة

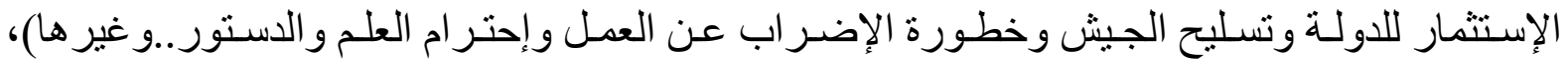

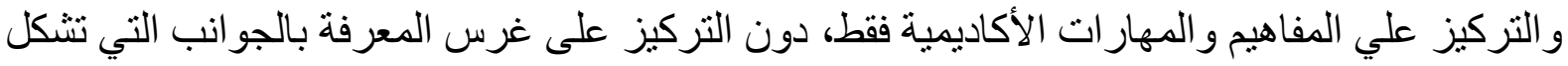
مصدر قوة للوطن أو المخاطر و التحديات الإقتصـادية و الإجتماعيـة والسياسية و العسكرية و البيئية التي تحيط به داخلياً وخار جياً وكيفية مو اجهتها.

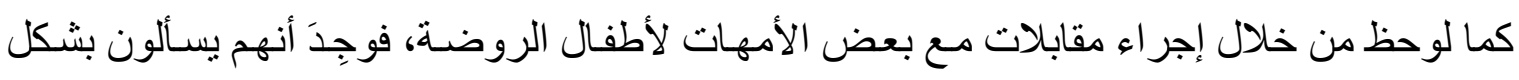

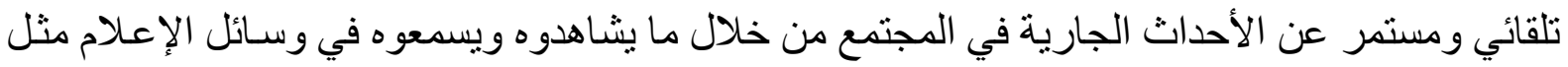

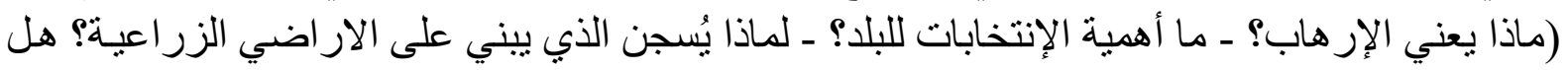

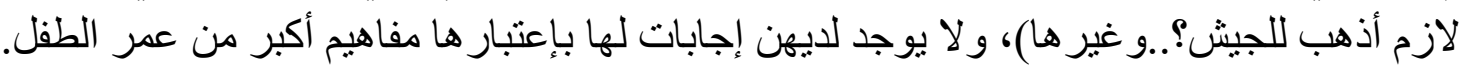

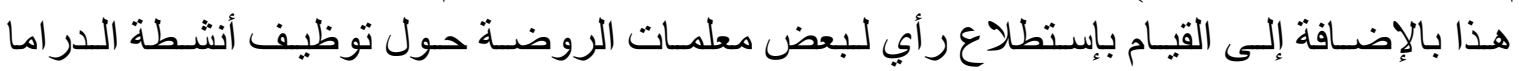
الإبداعية لتحث الأطفال على معرفة الأمن القومي لوطنهم وكيفية الحفاظ عليه، حيث أكدت النسبة الأكبر

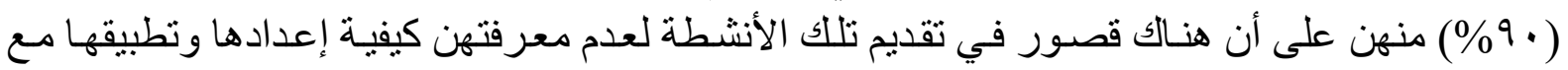

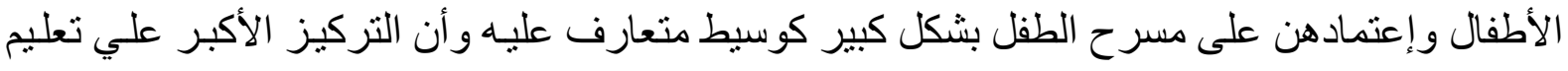

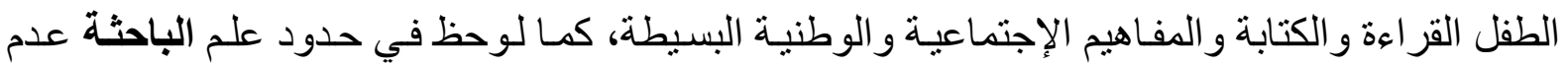

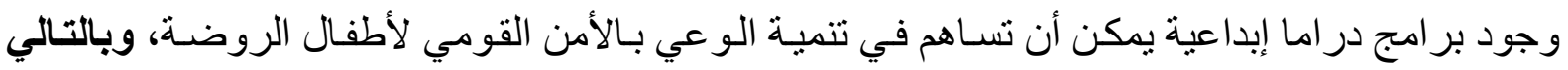
تبلورت مشكلة البحث في السؤال الرئيسي التالي:

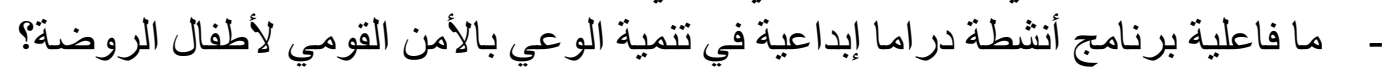
ويتفرع منه الأسئلة التالية:

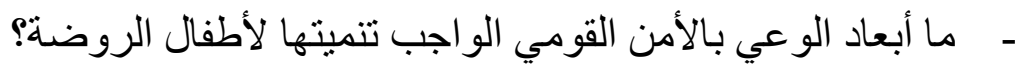

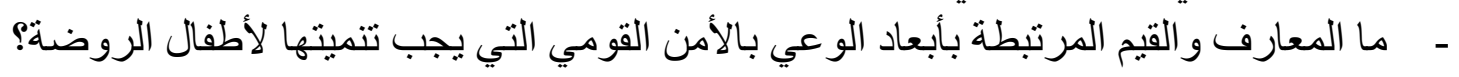

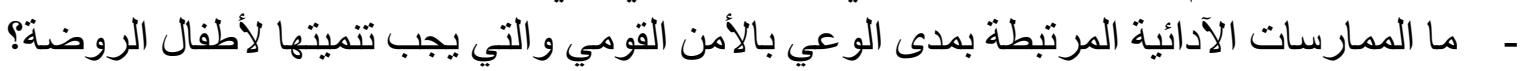

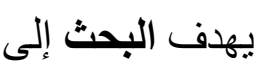

ا ـ تحديد أبعاد الوعي بالأمن القومي و المفاهيم المرتبطة بها المناسبة لأطفال الروضة.

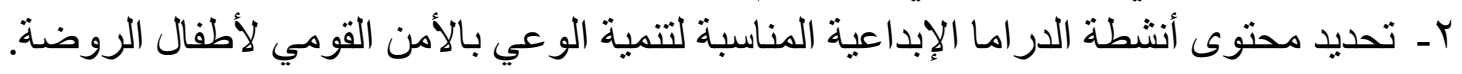

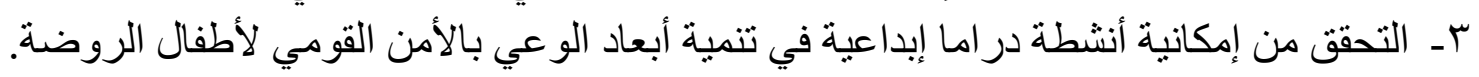
أهمية البحث:

تتمثل أهمية البحث في أهمية نظرية وتطبيقية كالتالي:

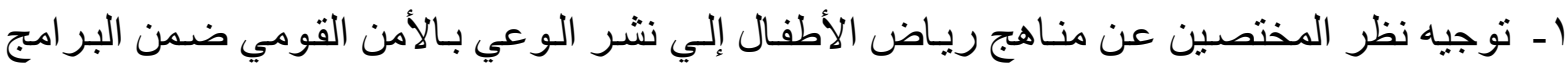

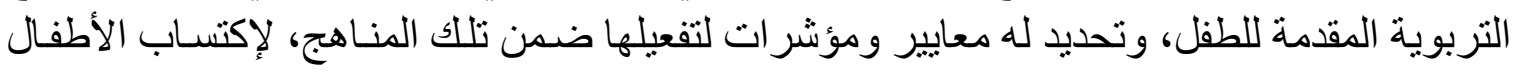

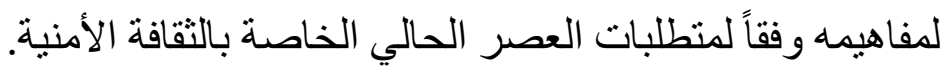

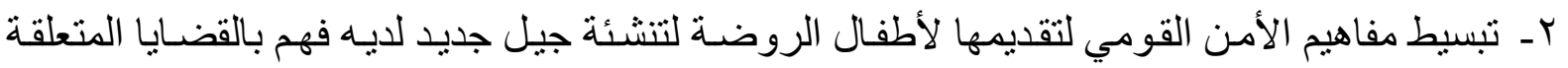

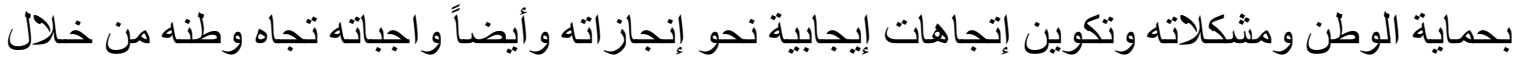

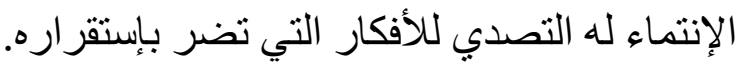


r- يقدم البحث برنامج تربوياً تعليمياً (برنامج أنشطة در اما إبداعية) يمكن الإستفادة منه في تفعيل دور

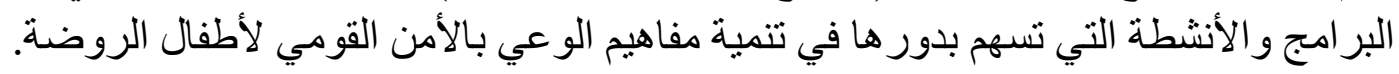

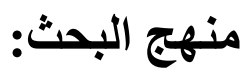

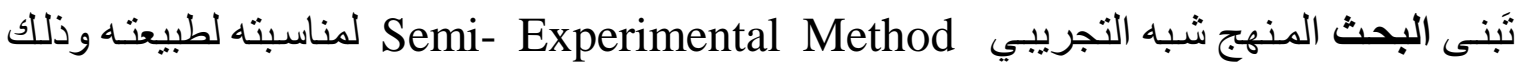

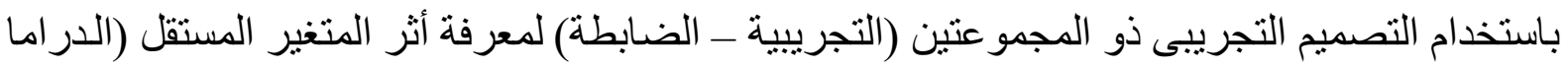

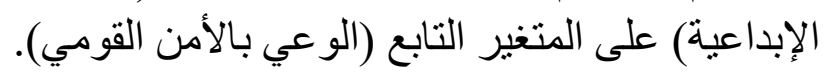
فروض البحث:

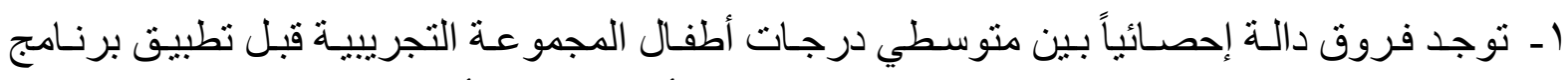

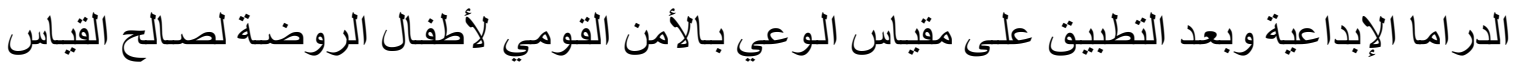

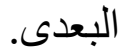

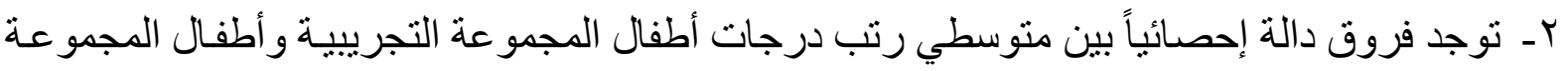

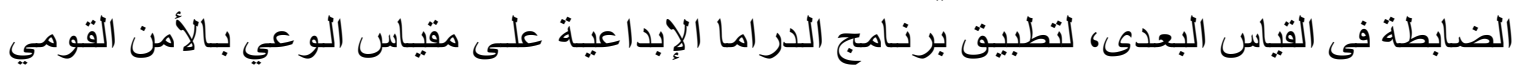

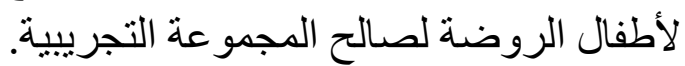

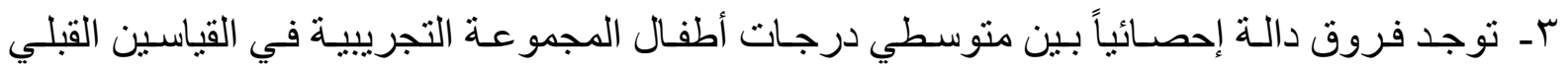

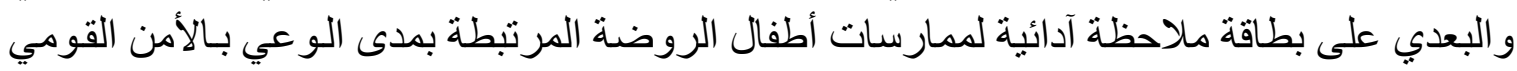

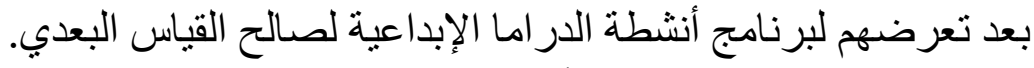

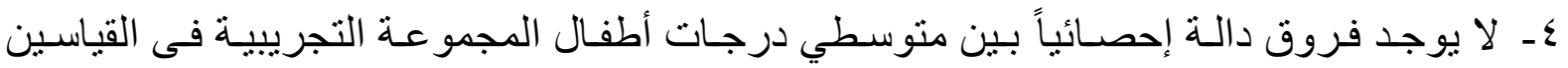

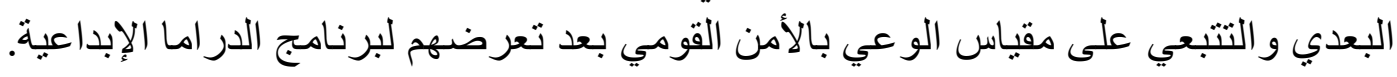

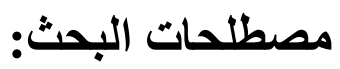
وقد عرفتها الباحثة إجر ائياً: ماته 1ـ دراما إبداعية Creative drama: هى مجموعة من المواقف الحياتية تتضمن مفاهيم إقتصادية

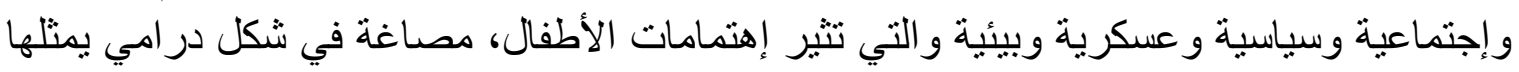

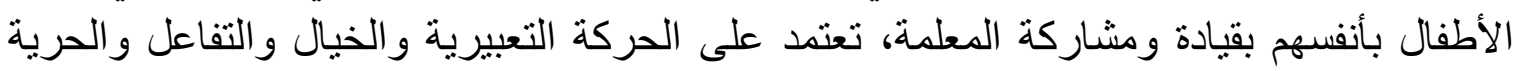

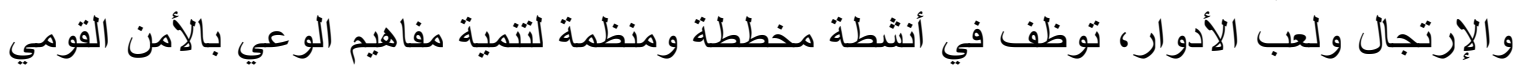
لو لوطنهم. - بو الإنجال

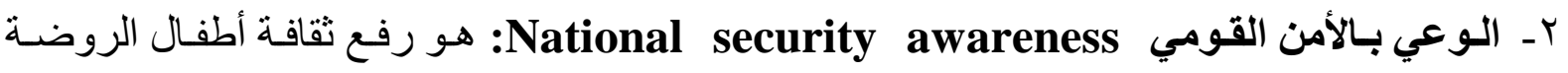

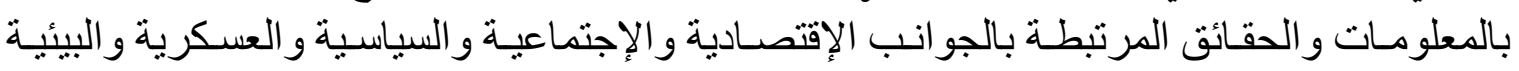

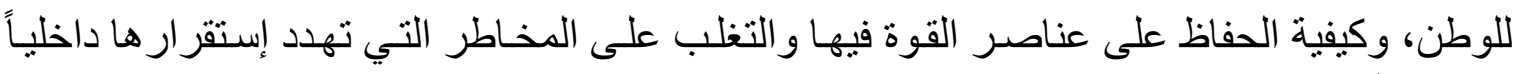

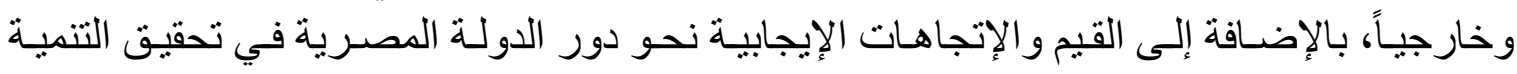

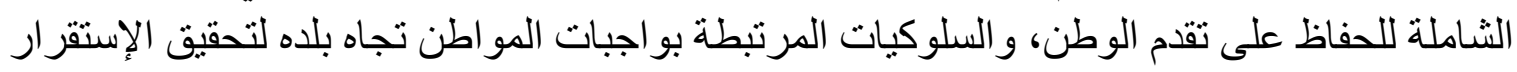

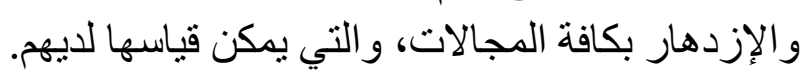

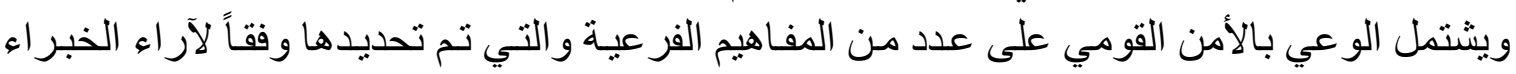

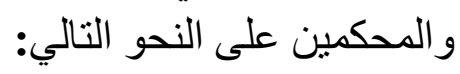
أمن قومي اقتصـادي: ويُعني بتنميـة معرفة الأطفال بأهمية توفير الأمو ال وكيفية إستنمار ها في البناء

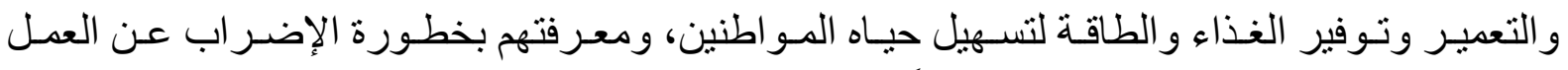

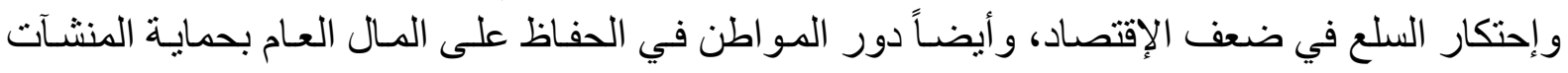
و الطرق من التخريب وأهمية المشرو عات الصغيرة التي تدعم دخل الدولة الدئ. 
أمن قومي اجتمـاعي: ويُعني بتنميـة معرفة الأطفـال بأهميـة توفير مسكن آمن ور عايـة صـحية مناسبة

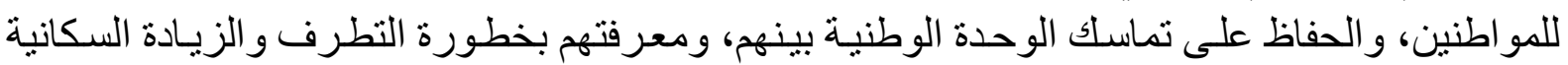

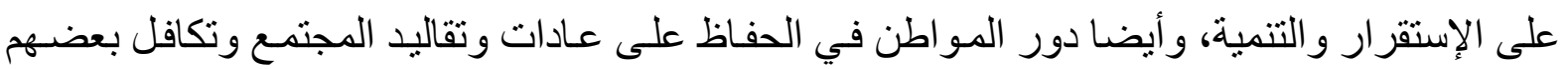

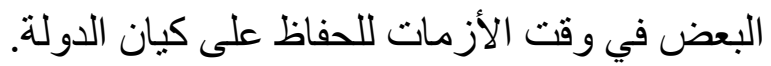
أمن قومي سياسي: ويُعني بتنمية معرفة الأطفـال بأهمية دعم الثـعب للقرار ات ات التي تكون في مصلحة

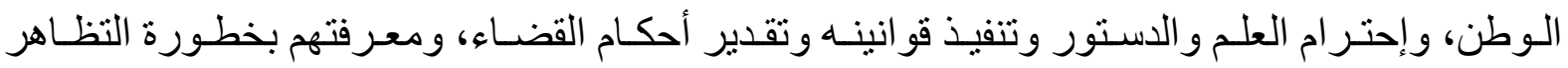
وتزييف الحقائق في إضعاف كيان الدولة، وأيضاً دور المواطن في التعبير عن رأيه من خلال الإنتخابات و أهمية مشاركة المر أة و إظهار إمكاناتها في تقدم البعاف فيلد.

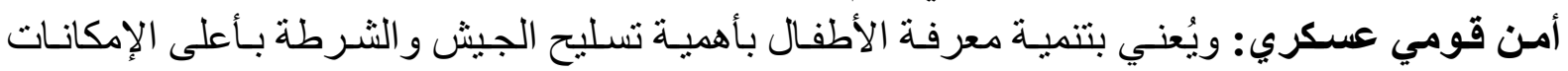

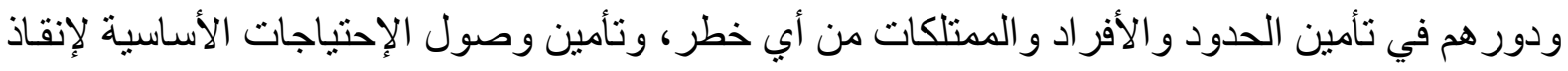

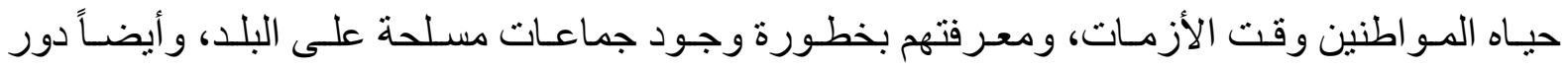
المو اطن بتقدير بطو لاتهم و إحتر ام القو انين العسكرية.

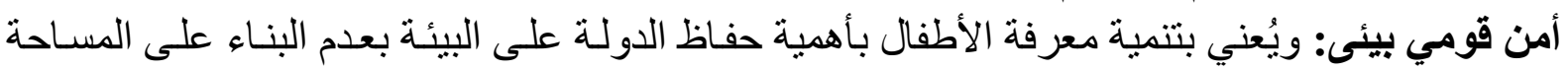

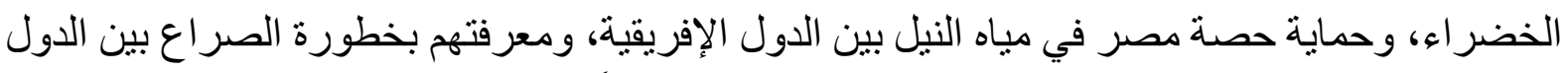

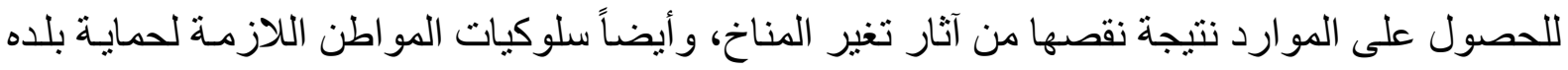

من آثار التلوث وتوفير إستهلاك الكهرباء و المياه و إستخدام الطاقة الثمسية كبديل آمن للبيئة. بـ أطفـال الروضـة Kindergarten Children: هـ الأطفـال الملتحقين بمرحلـة ريـاض الأطفـال

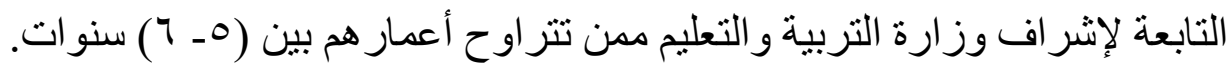
الإطار النظري ودراسات سابقة: سوف يتناول الإطار النظري محورين رئيسيين وهما:

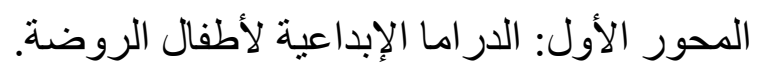

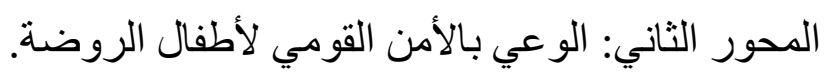

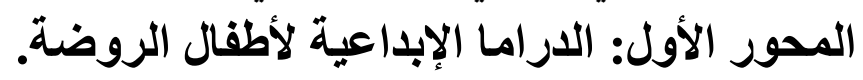

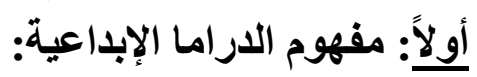

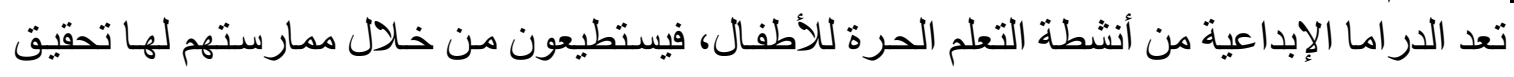
الكثير من الخبرات التي تؤدي إلى تأكيد القيم لديهم وتغيير اتجاهاتهم وبالتالي تعديل سلوكهم.

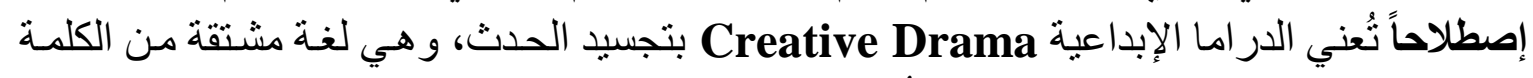

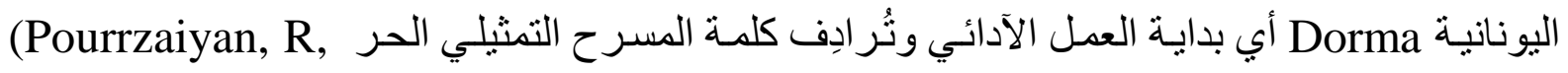
2013: 11) وتُعرف الدراما الإبداعية بأنها "شكل من أشكال لَعِب الأطفال ذو الطبيعة الدرامية الذي يمتاز بخضو عه للتقنين والملاحظة، ويهدف إلى مساعدة الطفل على النمو السوي وإثباع إلى إحتياجاته النفسية

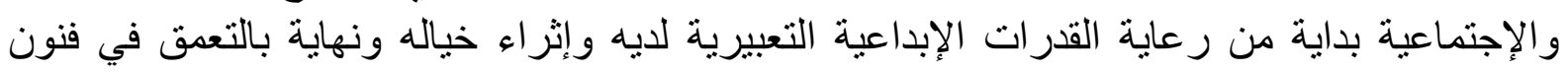

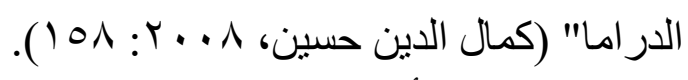

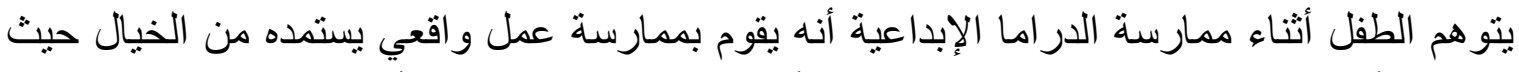
يُضفي على أثنياء من الواقع ما يرغب في تحقيقه أو التفاعل معه، إنعكاسا لأحاسيسه وتمنياته ور غباتهاته

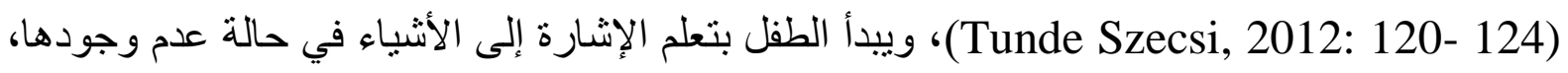


ويرسم صور عقلية لأحداث وممارسات وأثخاص في عالمه الحقيقي يحاول أن يحاكيها عن طريق القات

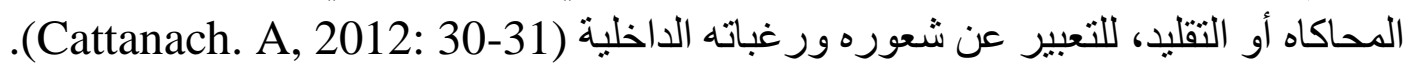

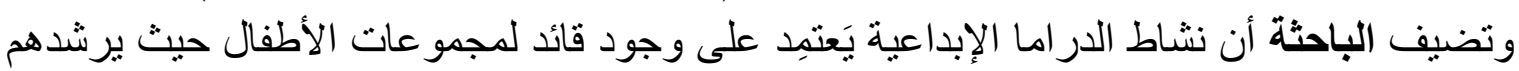

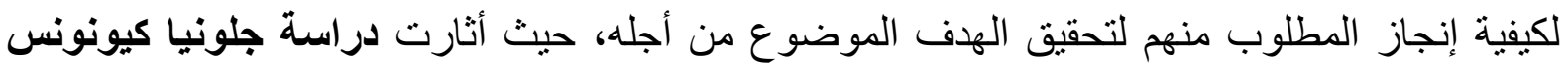

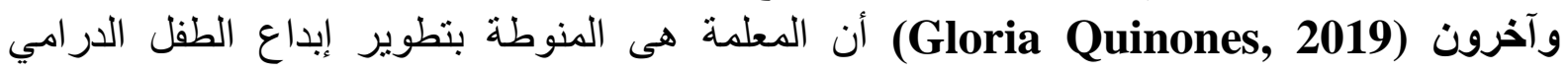

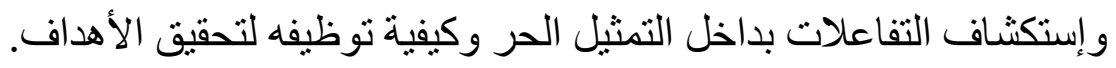

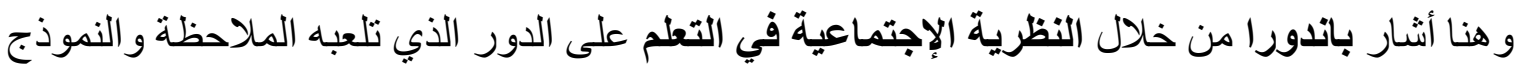

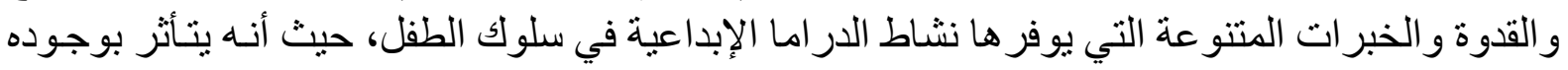

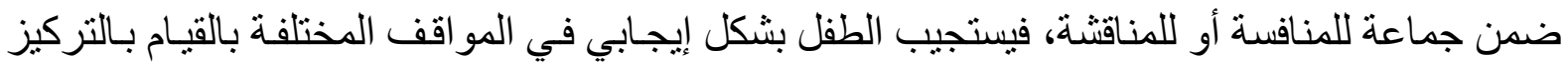

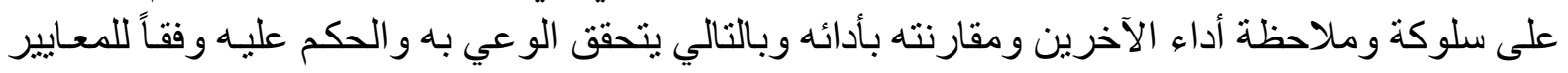

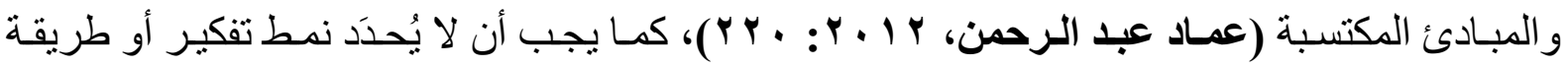

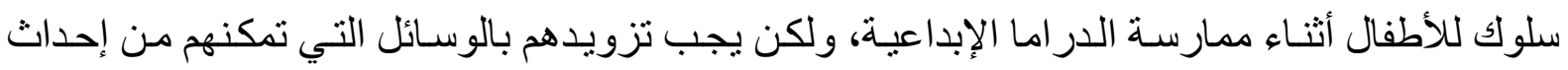

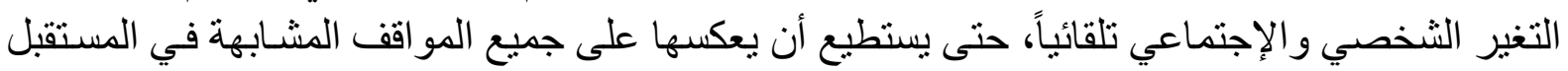

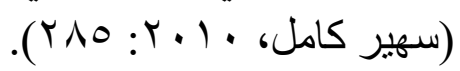

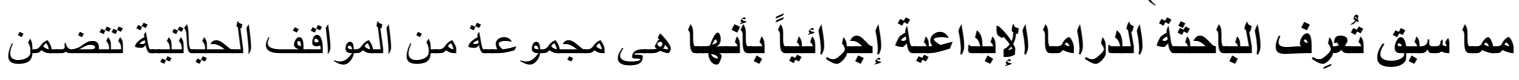

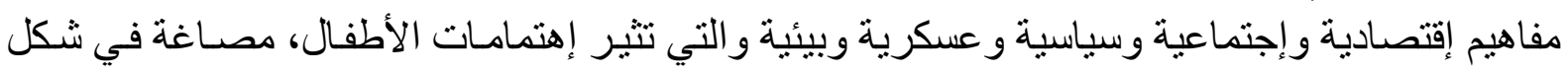

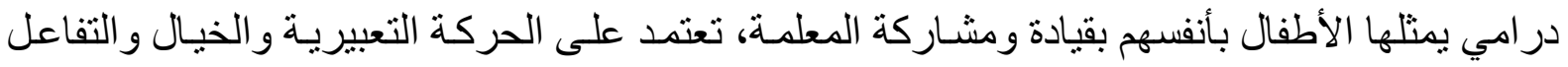

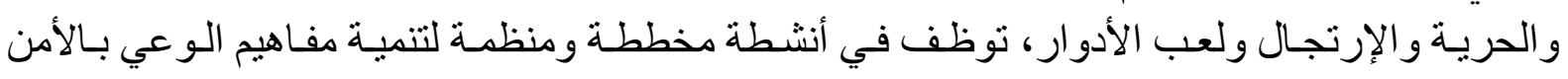

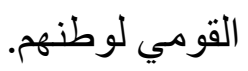
ثانياً: خصائص الدراما الإبداعية:

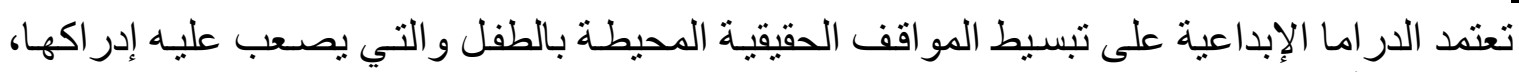

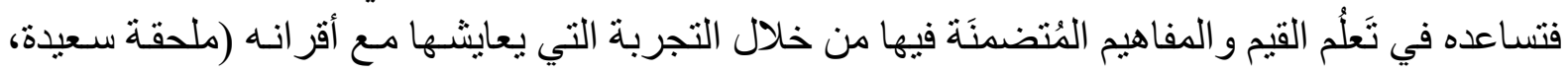
9

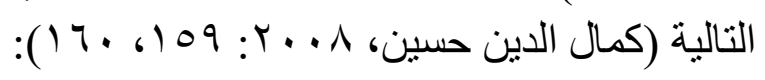

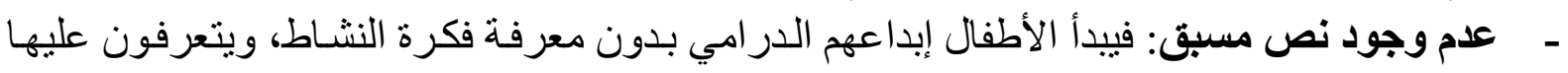

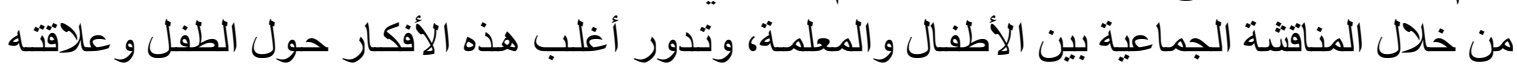
بالبيئة المحيطة بهاه وبالآخرين.

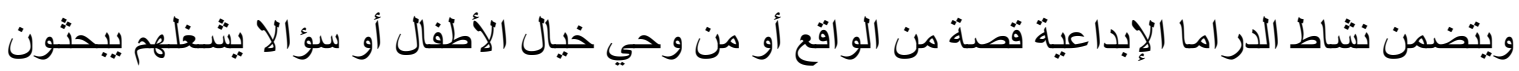

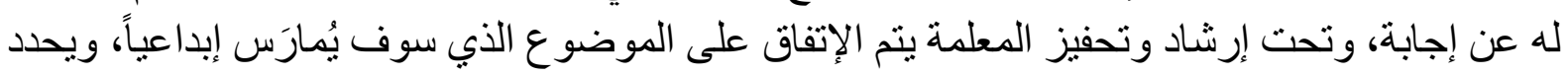

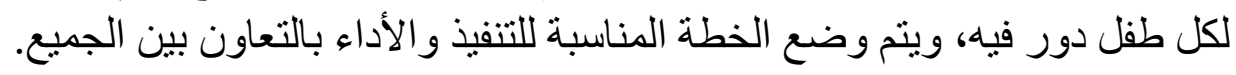

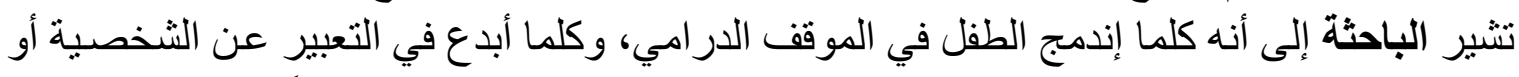

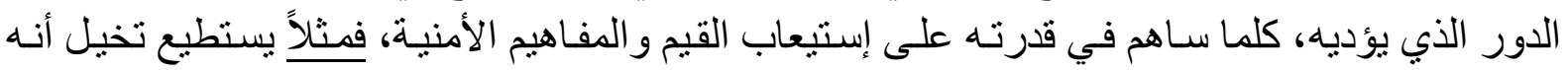

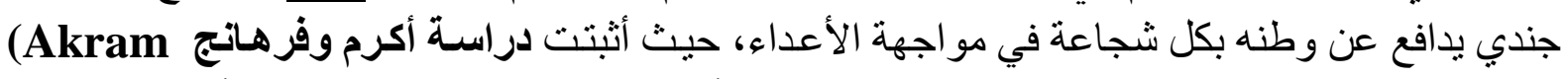
Ghasempour\& Farhang Mozafar, 2020) تتشيط ذهن الطفل تجاه تخيل الدور وتجسيده و الإبداع في أدائه.

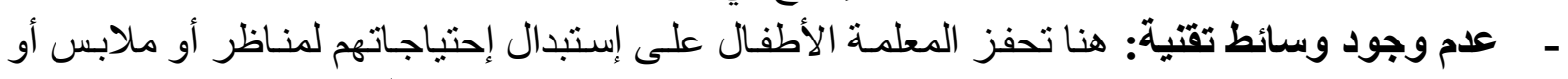

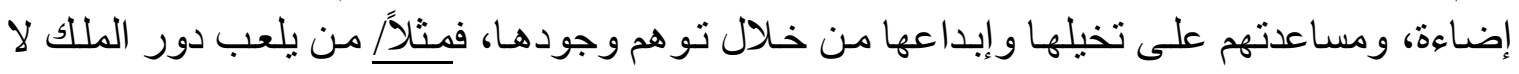




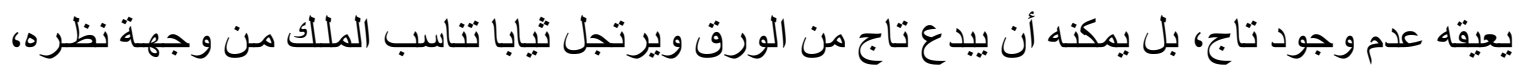

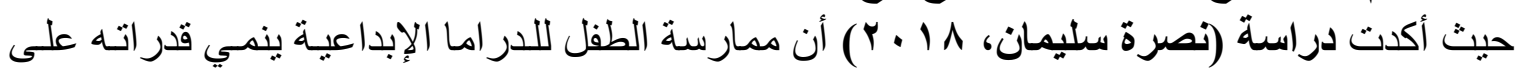
التفكير الإبتكاري.

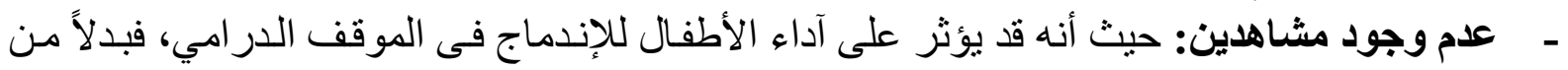

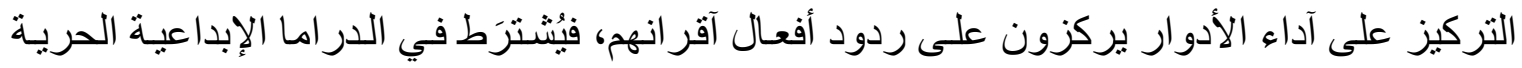

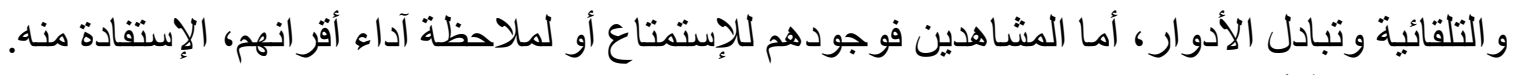

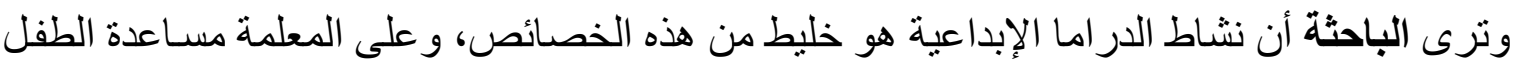

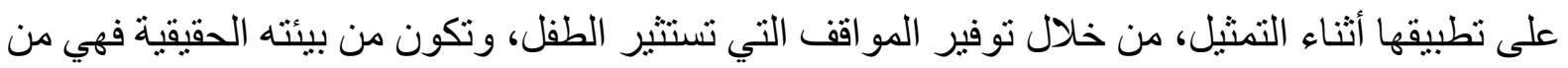

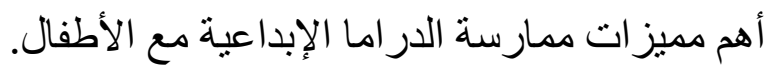

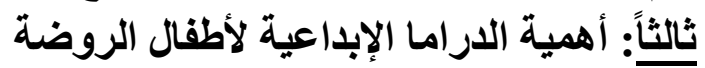

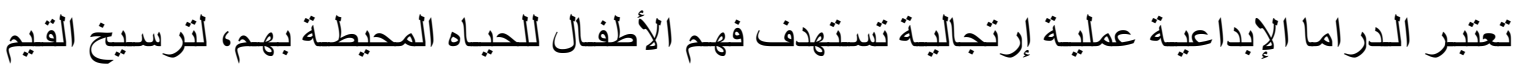

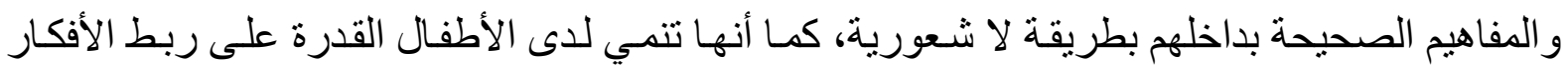

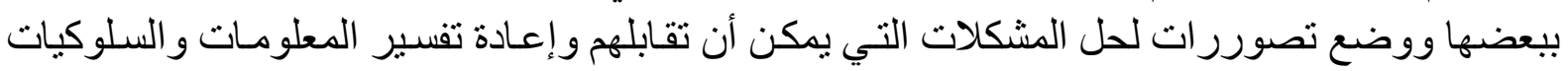

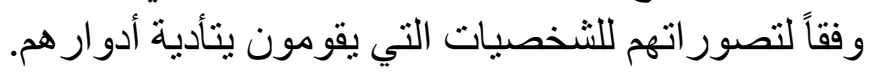

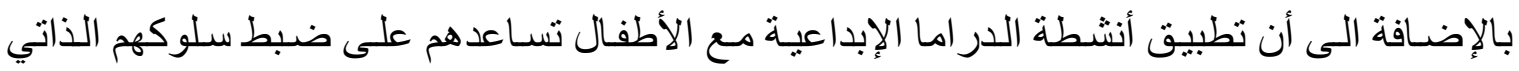

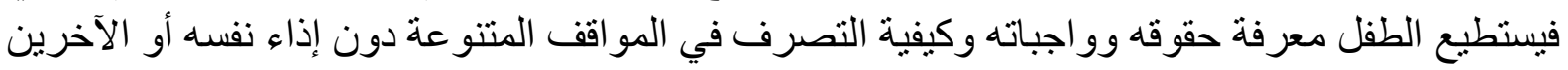

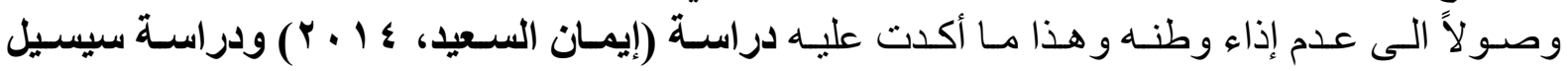

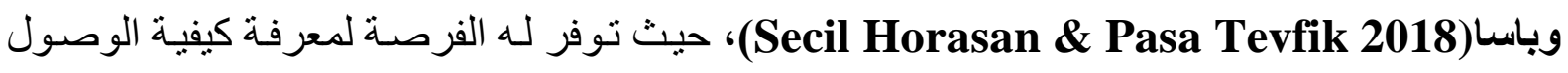
إلى أهدافه مع إحتر ام حقوق الآخرين.

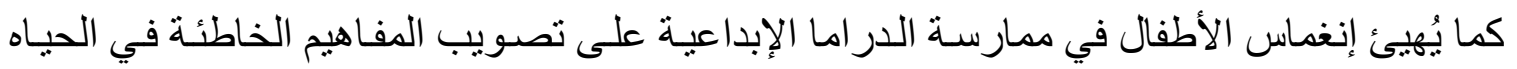

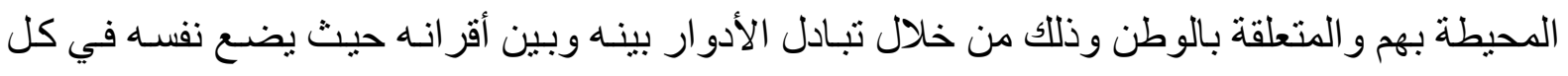

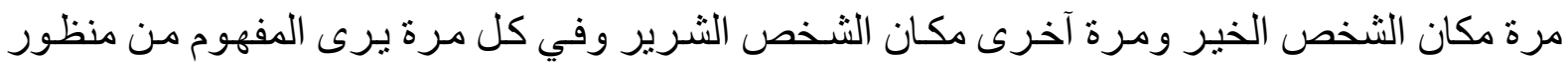

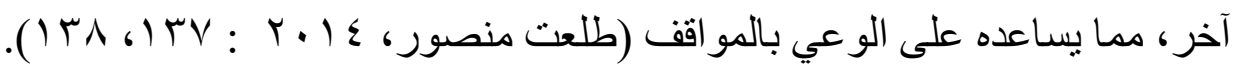

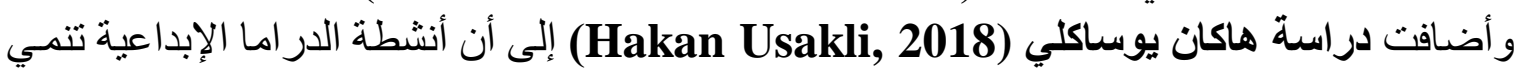

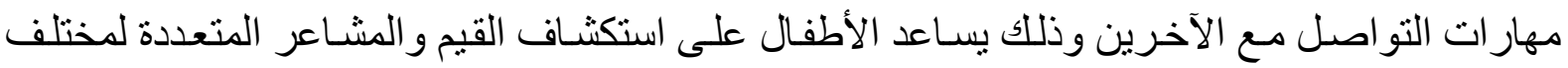

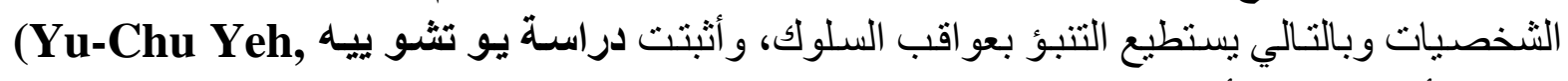

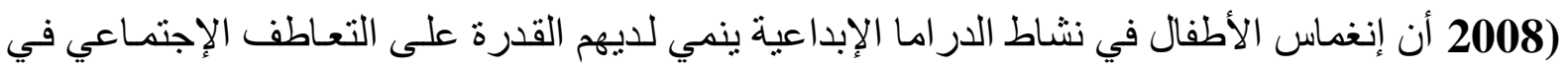
عمر صغير حيث يرسخ لقيم المجنمع الإيجابية وخاصاً الوطنية.

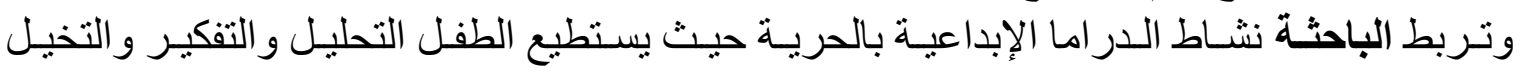

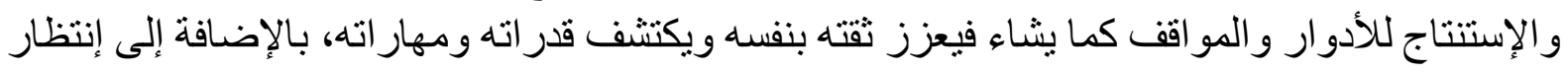

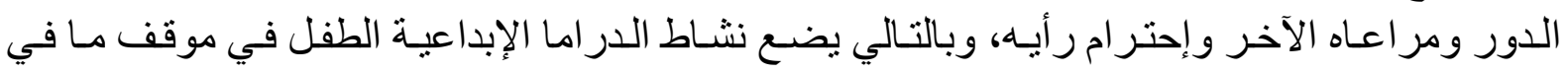

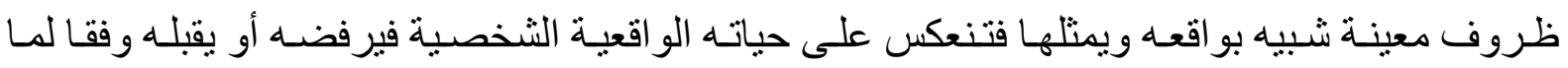

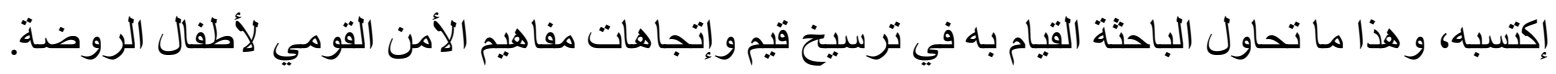

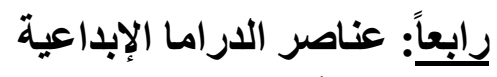

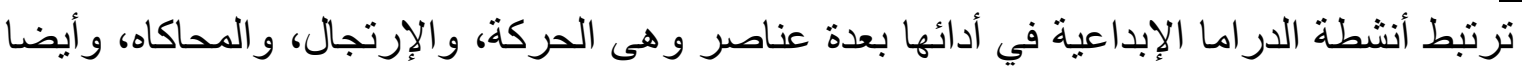

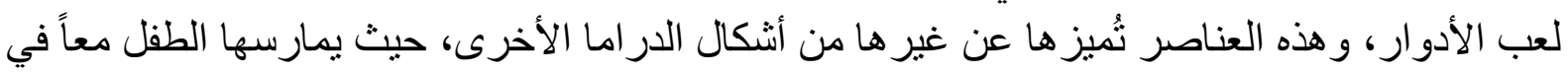

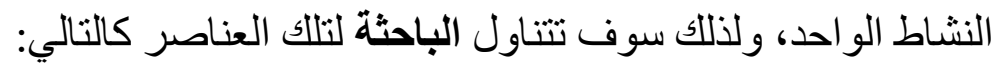


1- الحركة التعبيرية: Expressive movement

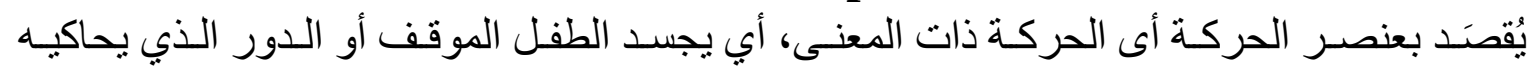

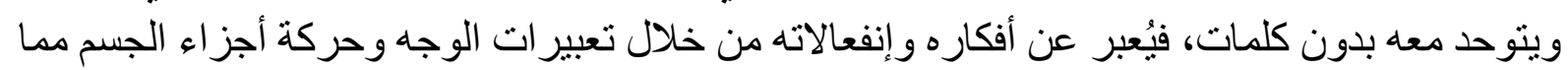

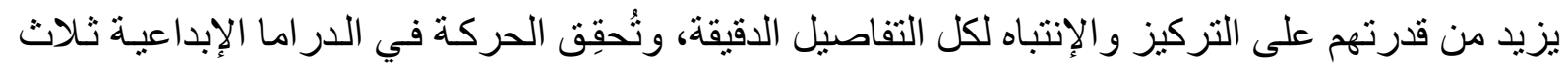

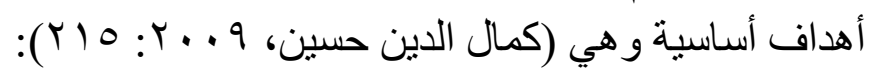

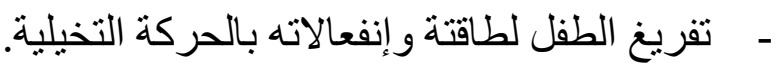

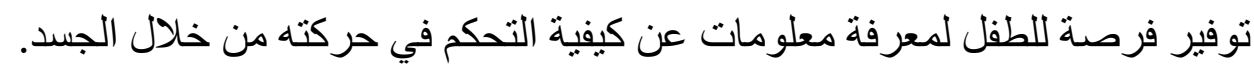

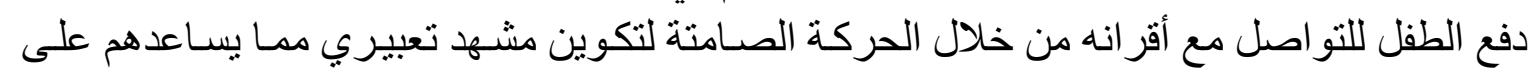
إدر الك الحاجة لها.

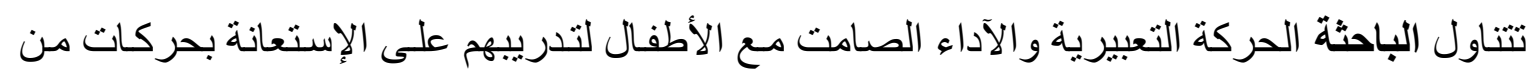

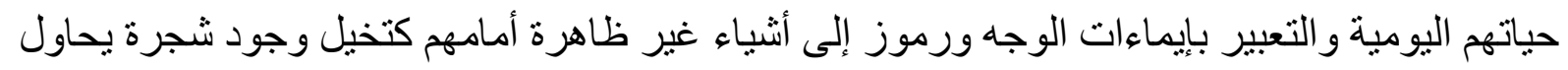

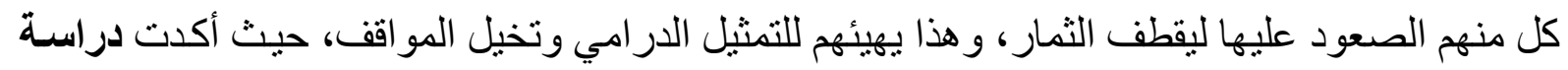

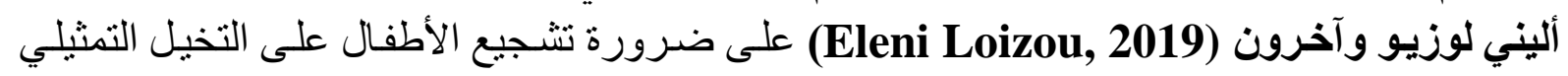

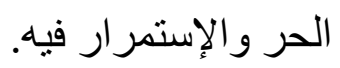

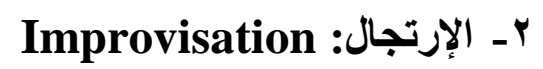

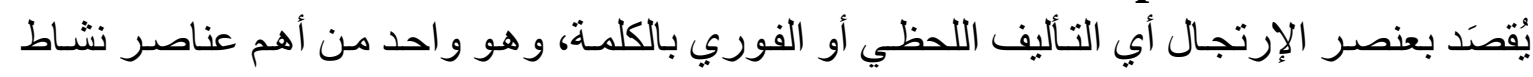

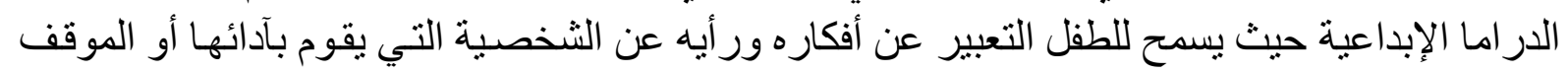

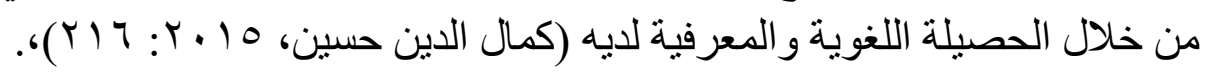

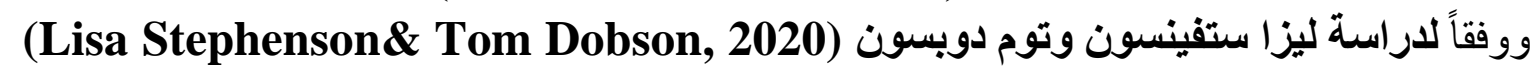

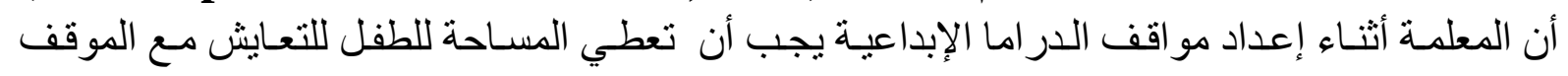

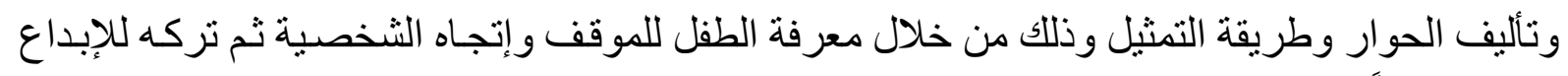

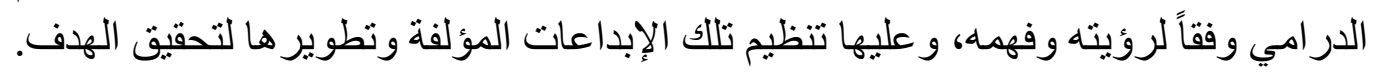

r- كب الألعوار: Role Play

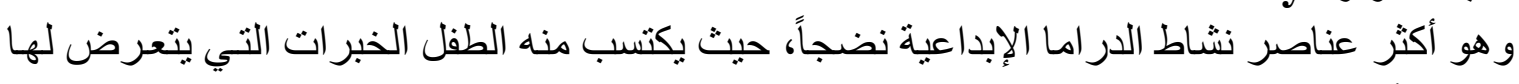

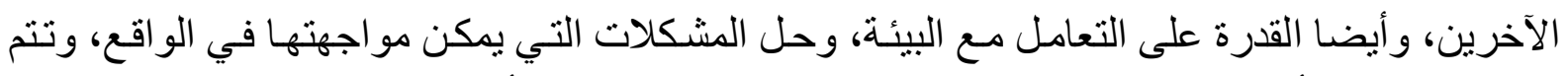

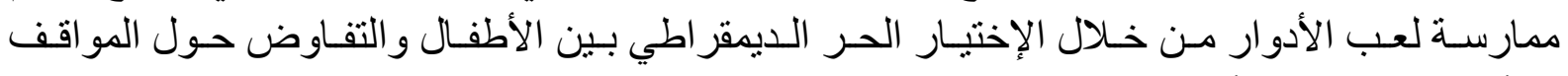

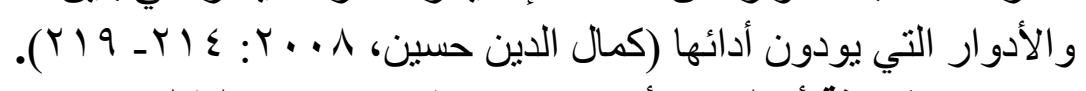

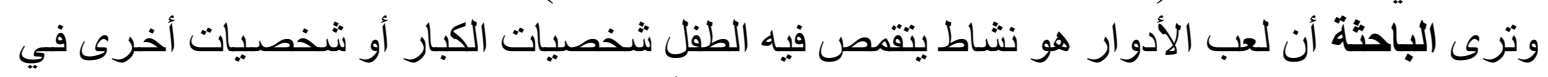

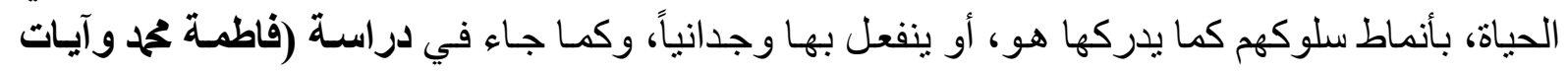

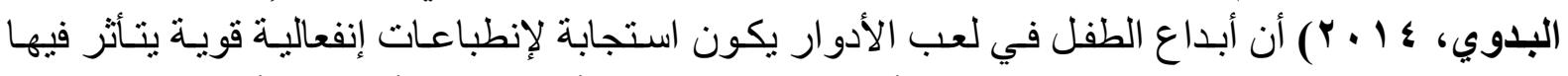

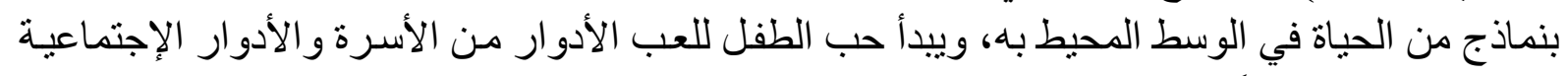

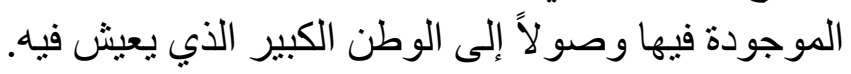

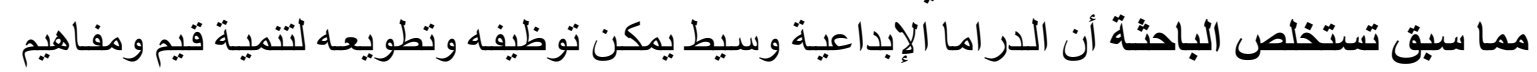

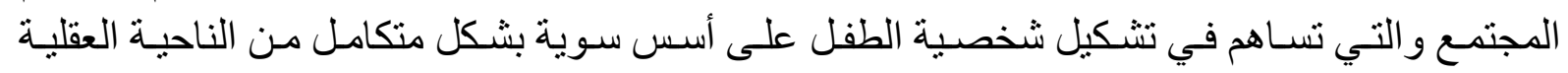

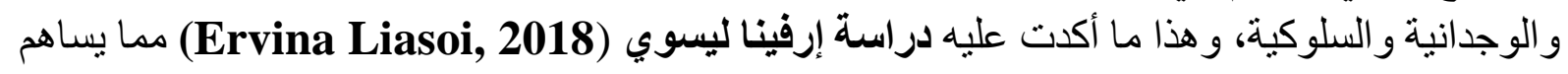

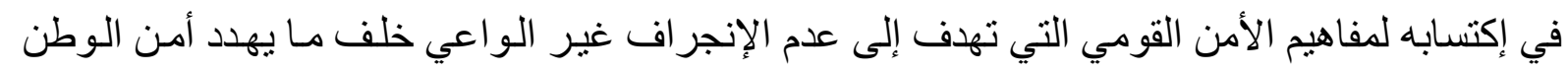

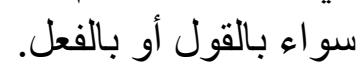




\section{المحور الثاني: الوعي بالأمن القومي لأطفال الروضة.

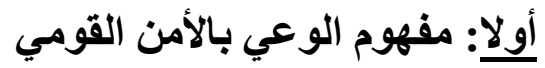

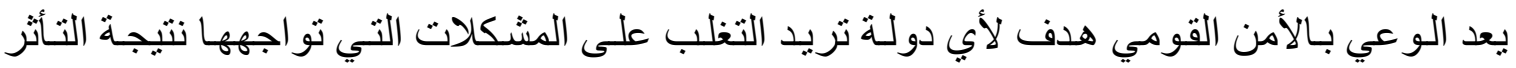

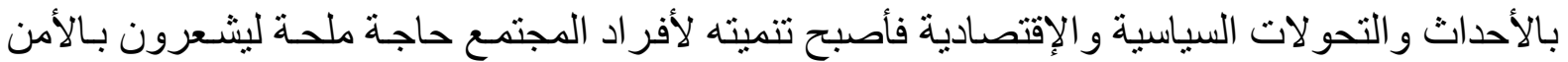

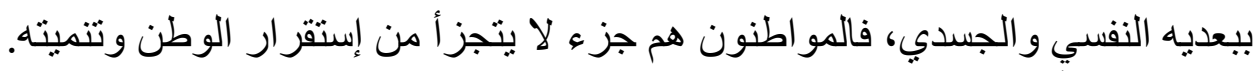

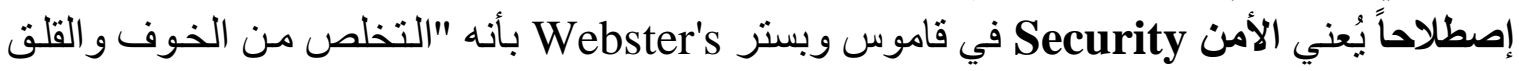

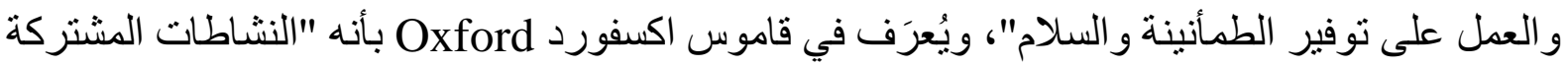

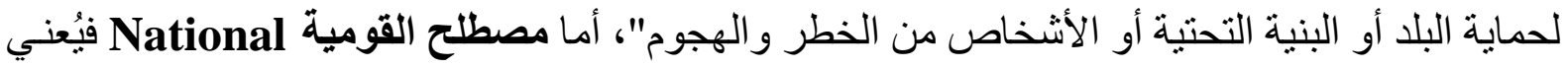

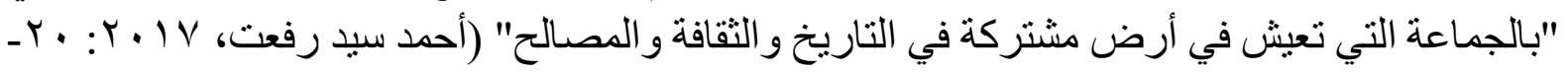

ولم يقتصر مفهوم الأمن القومي National Security على جانب حماية الدولة من المخاطر فقط،

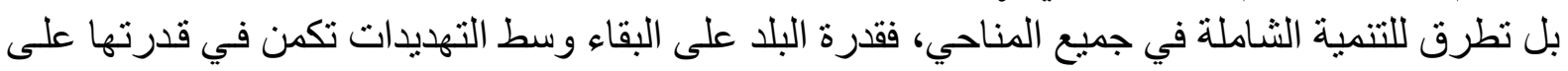

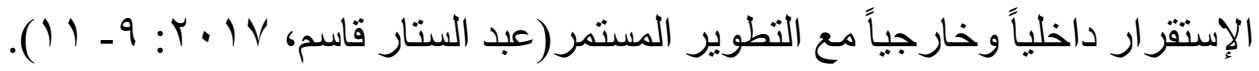

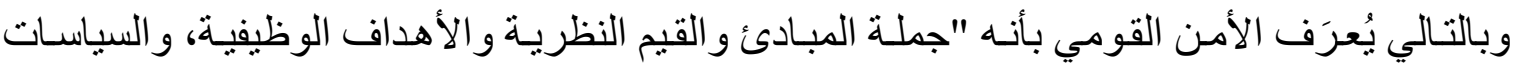

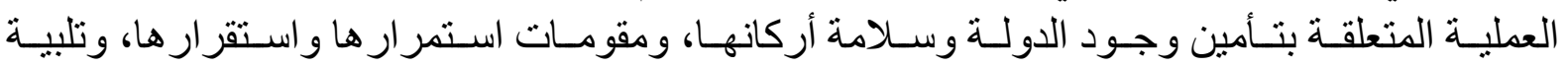

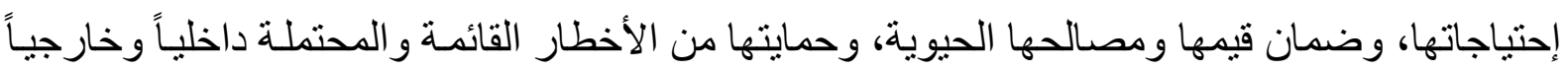

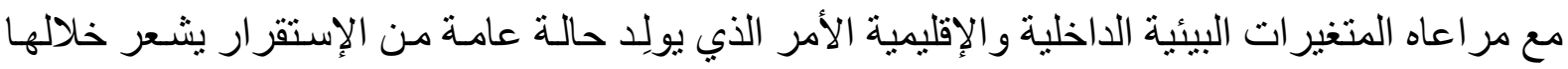

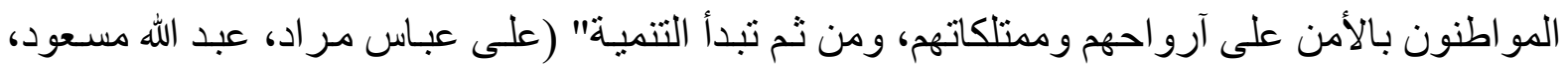

(IV:r... T ويبدأ تحقيق الأمن القومي بداخل الوطن بفهم المواطنين لمعنـاه و إكتسـاب قيمهـ وتقدير الممارسـات

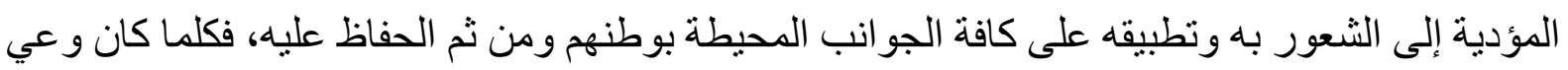

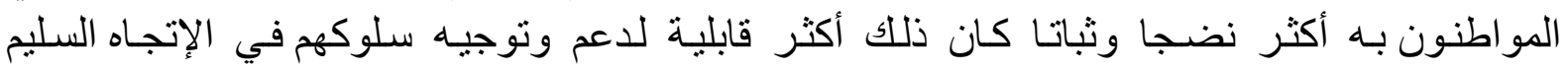

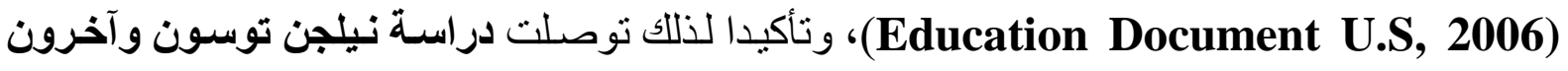

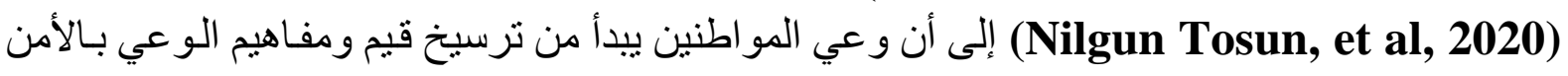

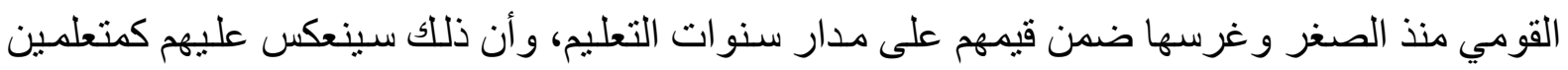

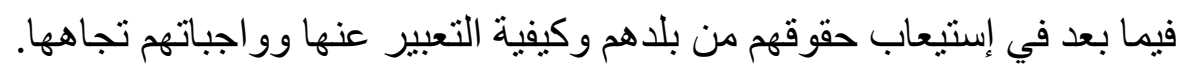

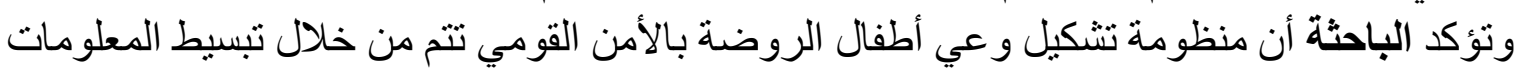

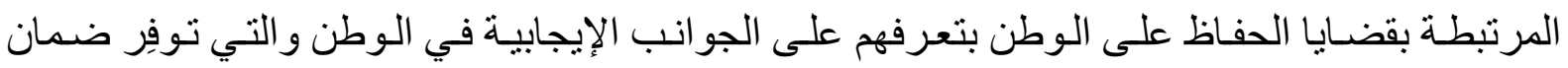

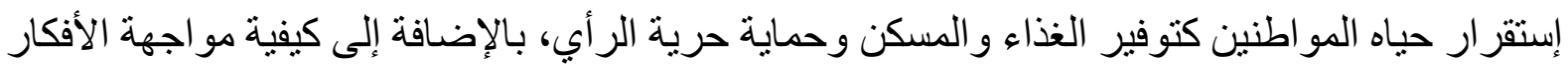

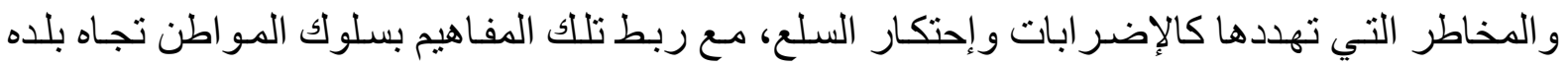

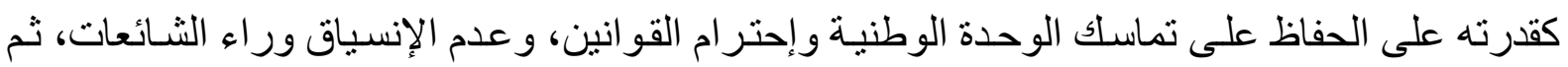

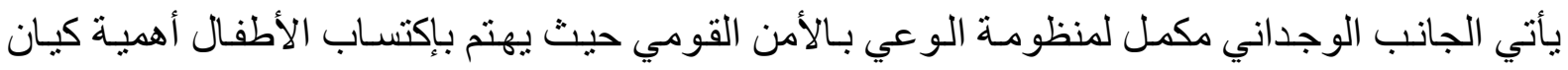

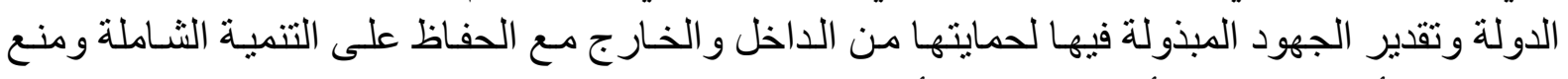

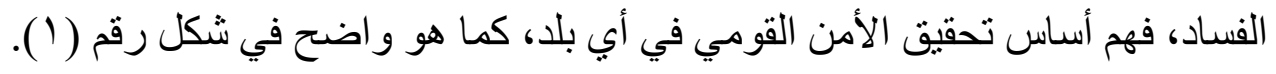




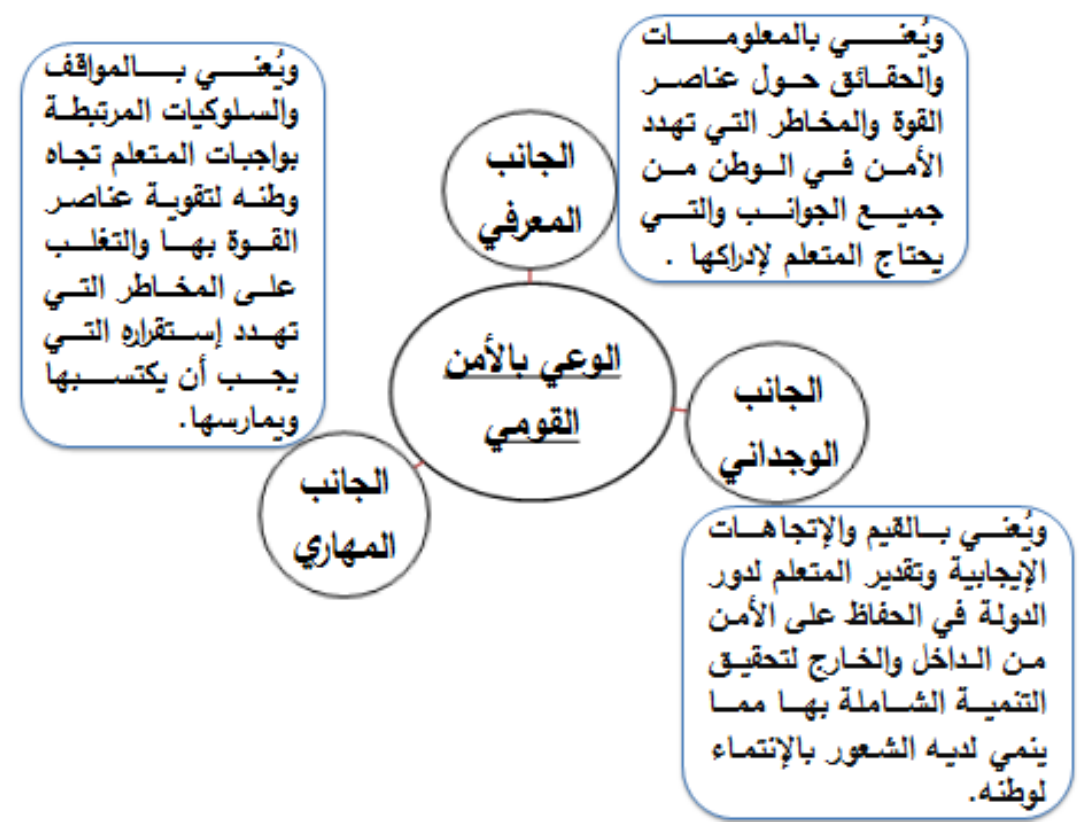

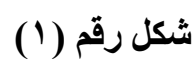

رسم توضيحي لتشكيل منظومة الوعي بالأمن القومي لدى المتعلم (من وجهة نظر الباحثة)

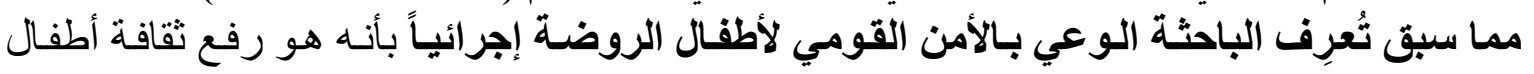

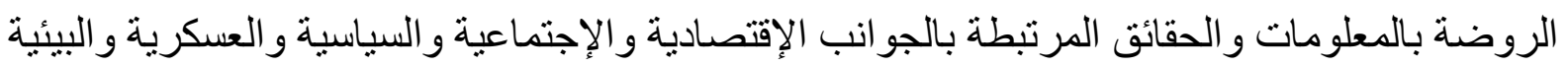

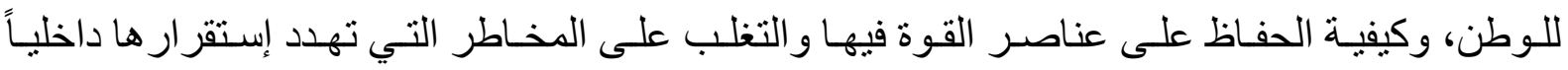

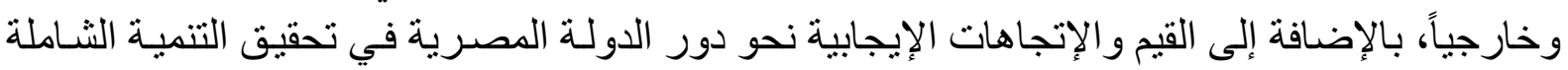

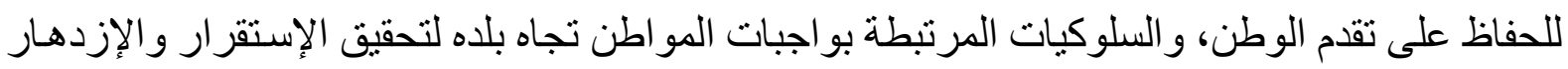

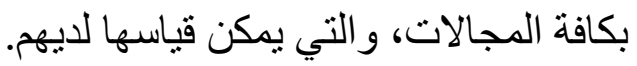
ثانيا: النظريات التربوية في مفهوم الوعي بالأمن القومي لأطفال الروضة

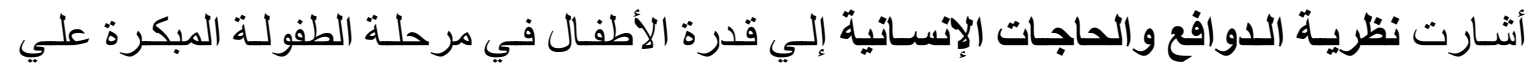

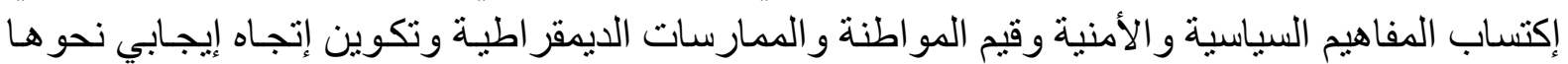

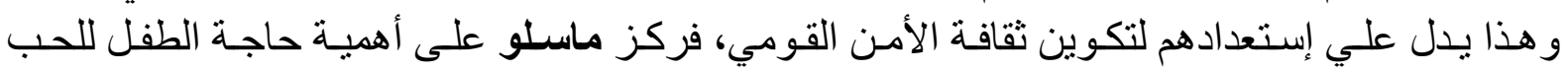

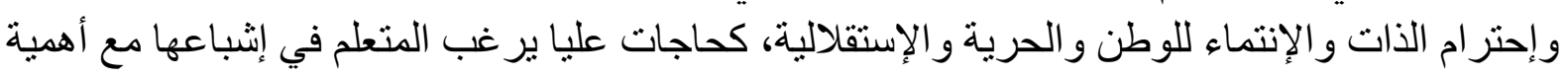
توفير الفرص لتحقيق هذا الإشباع. كما إهتم بالمبادئ الإنسانية لجعل التعلم أكثر إنسانياً وإحتر اما لقيمه وفقأ لإستعدادات المتعلم و إمكاناته،

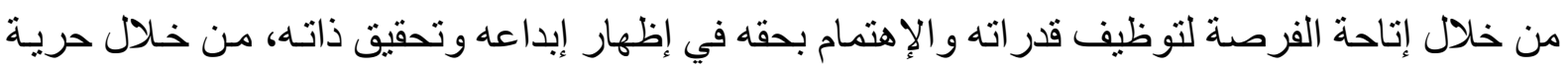

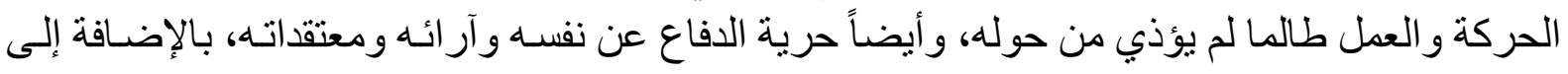

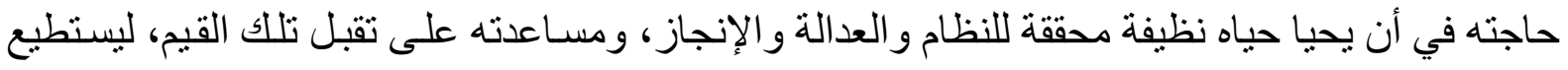

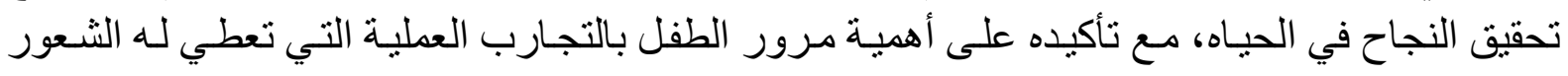

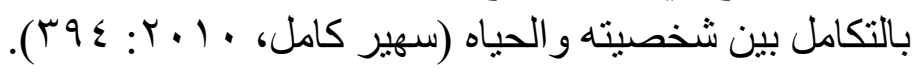

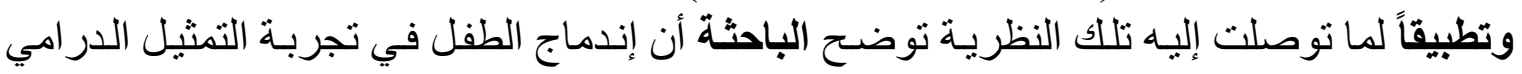

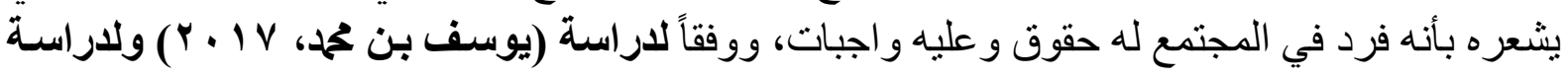

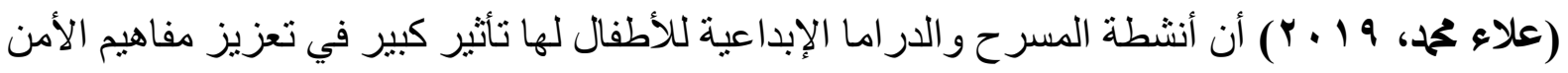


أما بياجيه فأكد على أنه من الضروري تنتئة الأطفال على مفاهيم حماية الوطن منذ الصغر التأثنير هـا

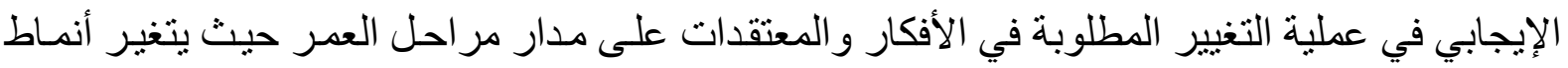

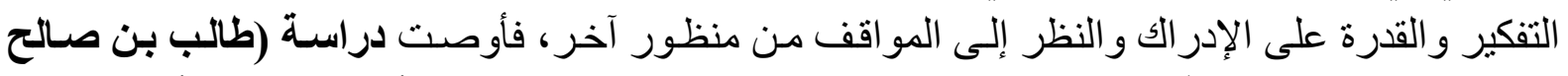

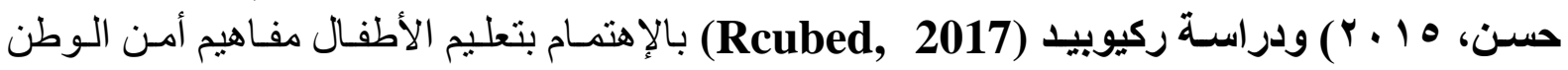

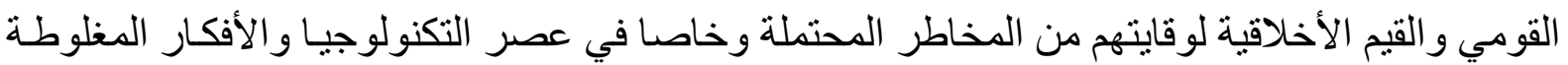

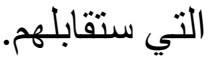

ثالثاً: أهمية الوعي بالأمن القومي لأطفال الروضة

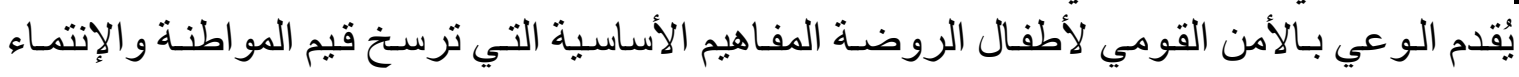

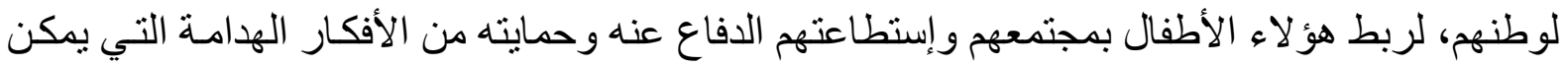

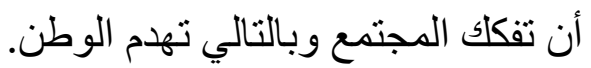

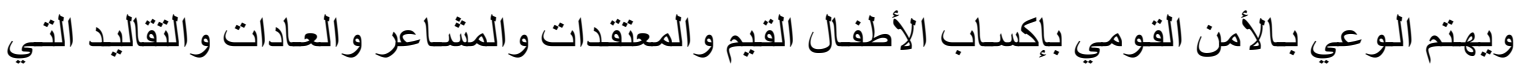

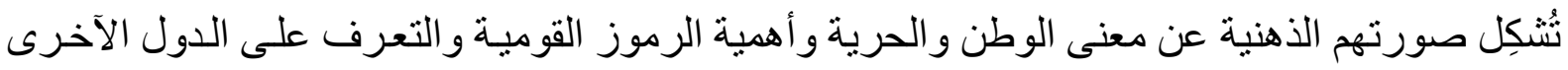

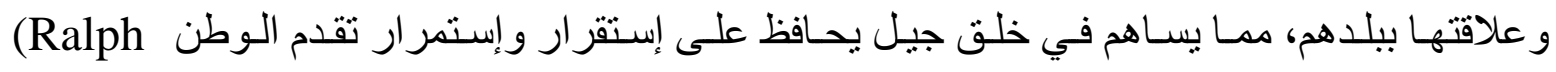
.Doughty et all , 2015: 171-173)

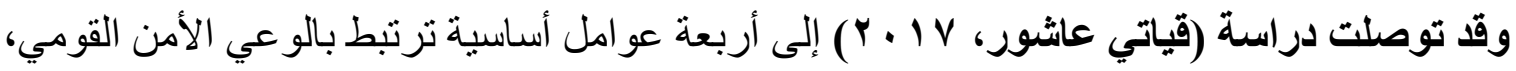

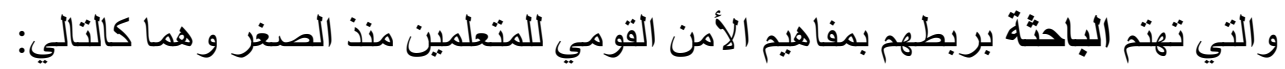

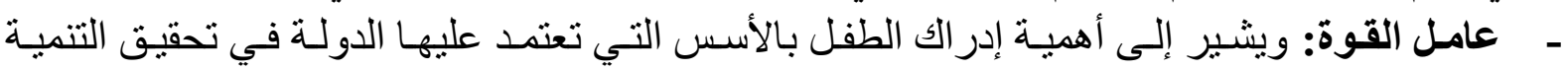

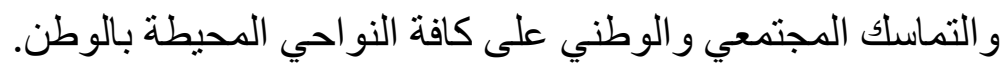

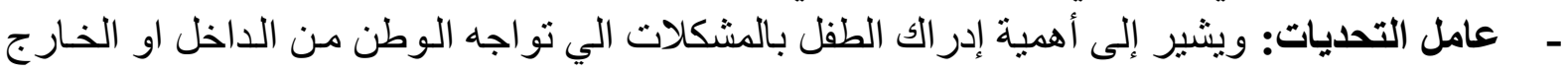

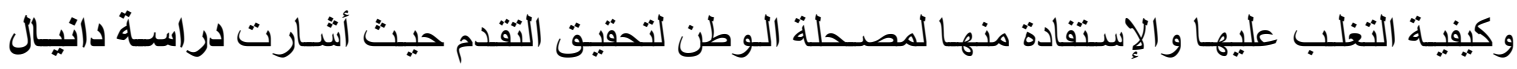

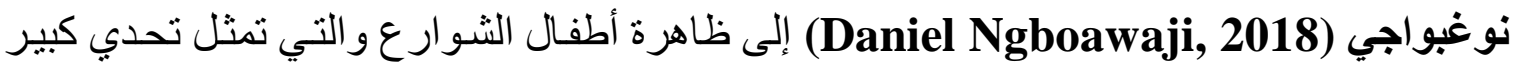
اللدولة يؤثر على الأمن القومي في قارة أفريقيا.

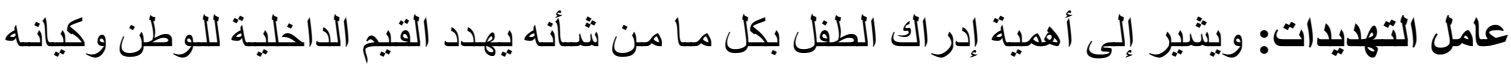

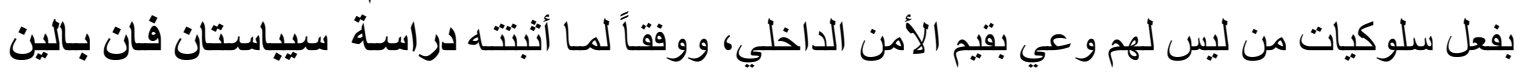
(Sebastian Van, 2018) القوى المعادية للوطن.

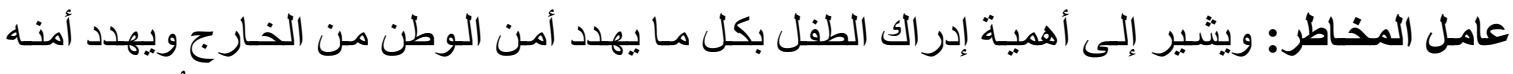

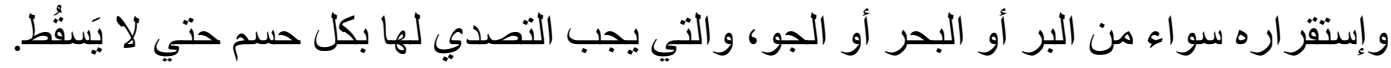

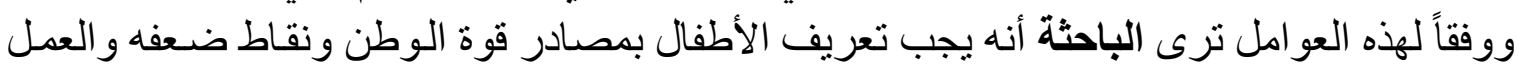

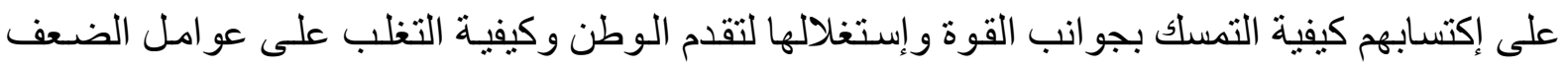

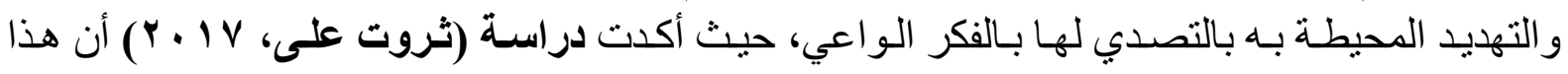

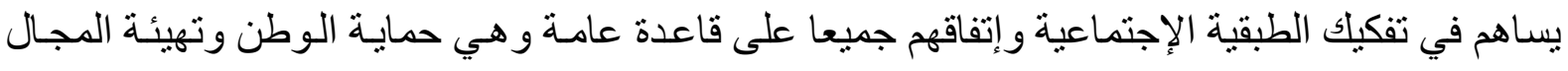

لتنميته.

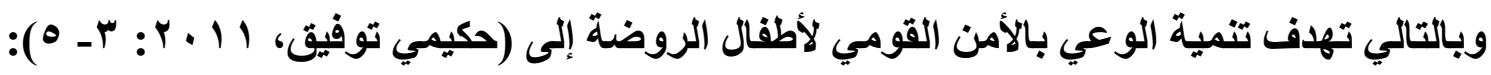

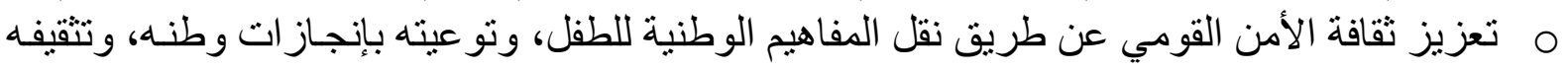
بالأهمية الجغر افية و الإقتصادية للوطن لون 
م توجيه إنتباه الطفل لما تقوم به بلده من خطط ومشرو عات تنموية وأمنية تساهم في تقدم البلد و الحفاظ على هويتها بين البلاد الآخري. م تعليم الطفل المعاني التي يرمز لها علم بلاده، وقيمة النثيد الوطني في نفوس الأفر اد و إحتر ام قادة الوطن.

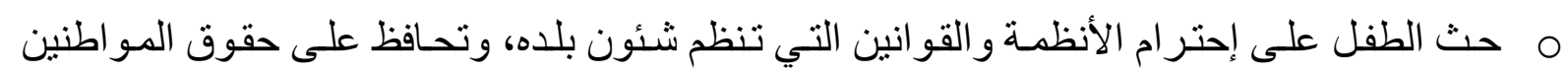

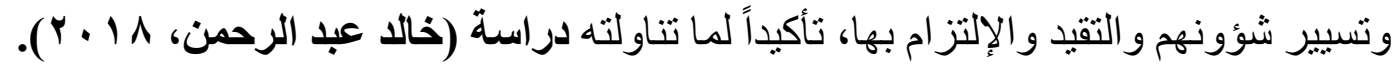

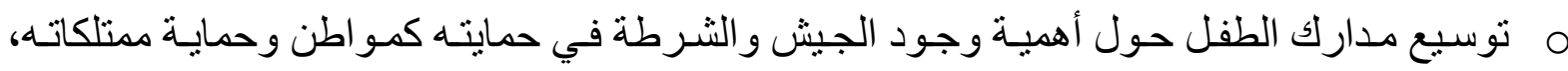
وخطورة تفكيك الجيوش على هلى هدم الوطن.

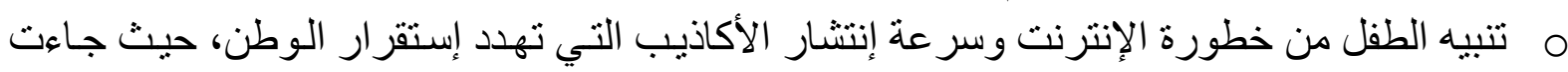

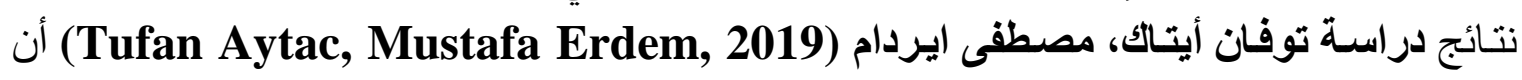

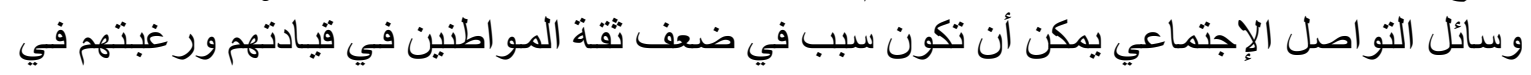
النجاح و التقلم. م توجيه إنتباه الطفل لمعني التطرف الفكري وتزييف الحقائق ووجود جماعات مسلحة وخطورتهـ على مسار التقام وتفكيك الوطن.

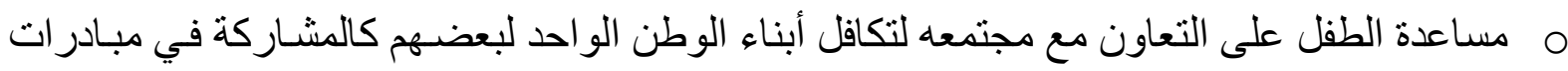

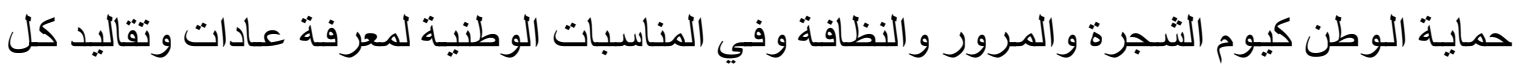

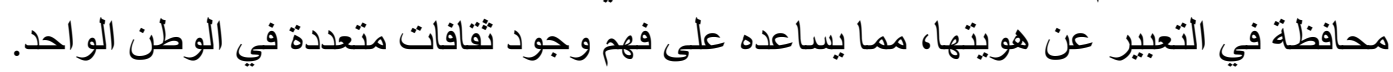

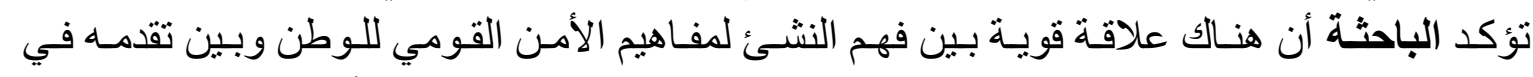

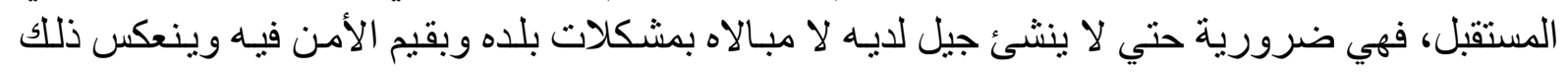
على إنتماءه وحبه لوطنه.

رابعاً: أبعاد الوعي بالأمن القومي لأطفال الروضة

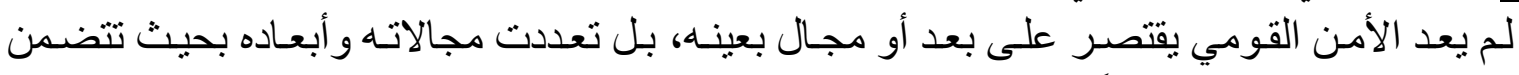

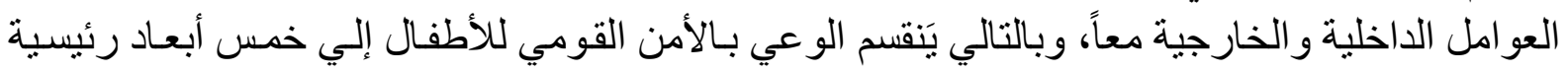

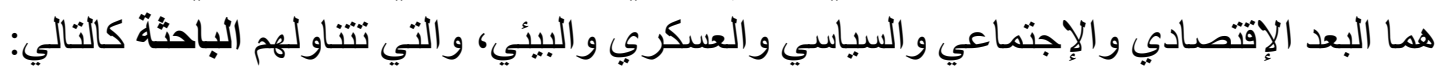

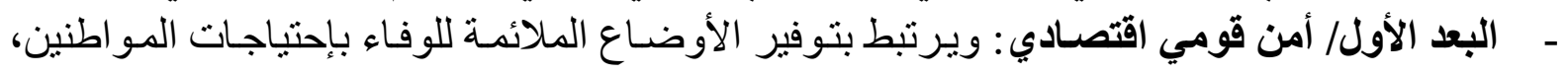

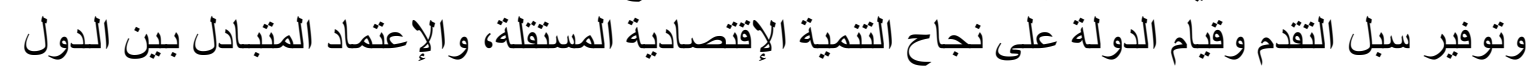

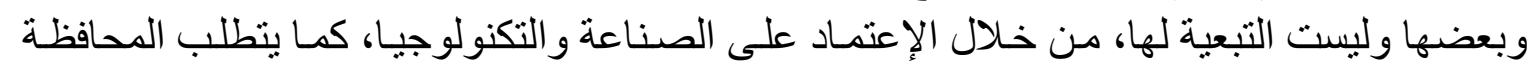

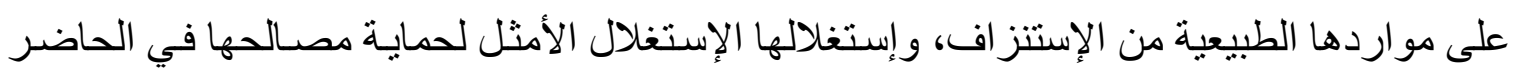

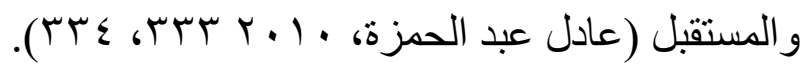

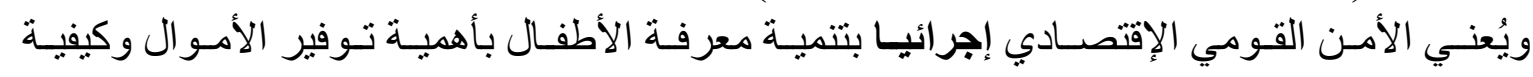

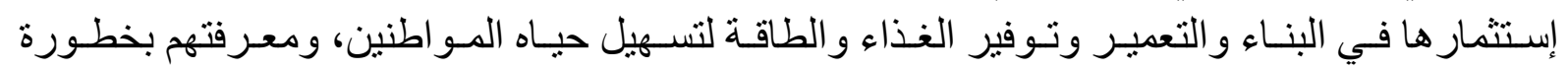

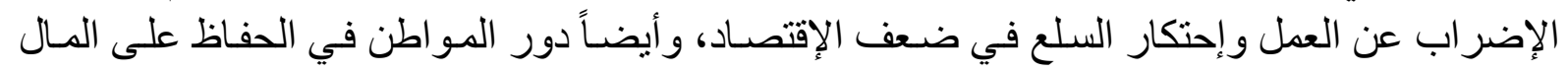

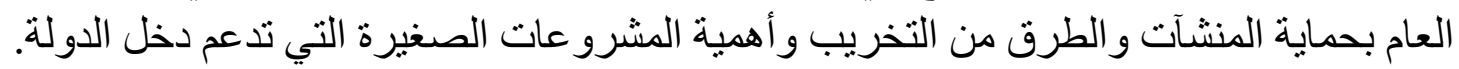

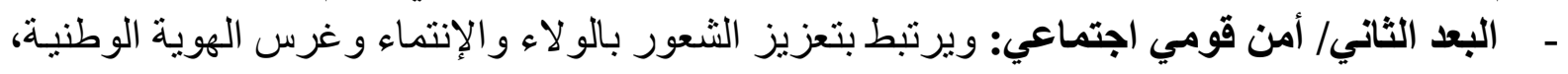

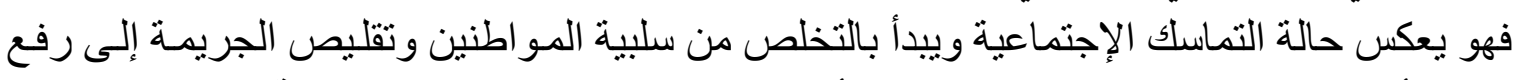

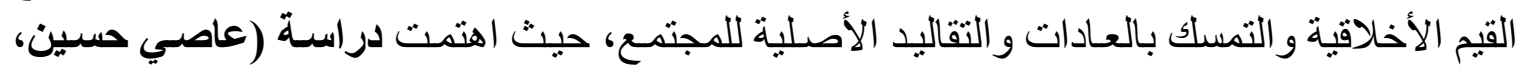




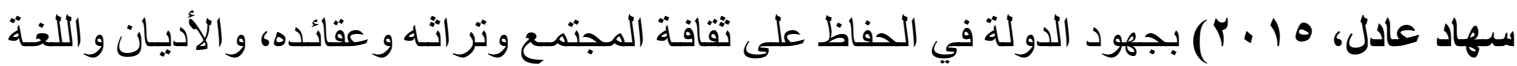
و الأفكار المرتبطة بكل بيئة وحمايتها وتقبل الإختلافات بينها، فالمجتمع الذي تنهار ثقافته يفقد تر ابطه

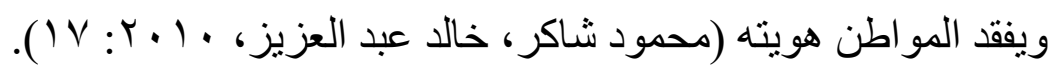

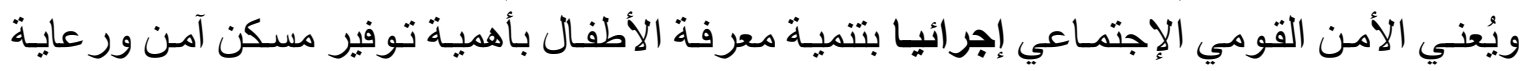

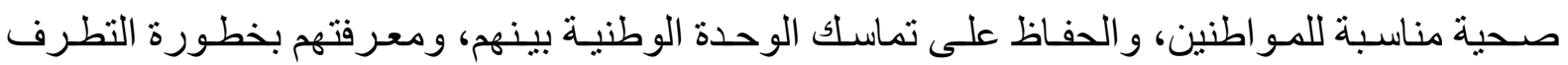

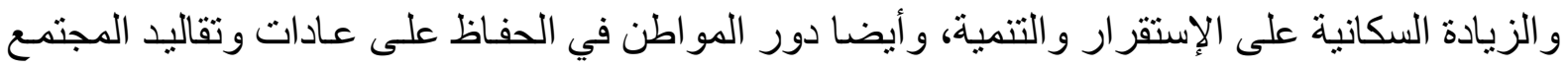
وتكافل بعضهم البعض في وقت الأزمات للحفاظ على كيان الدولة.

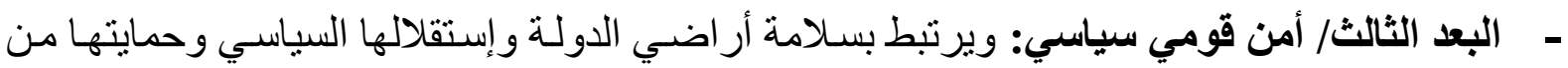

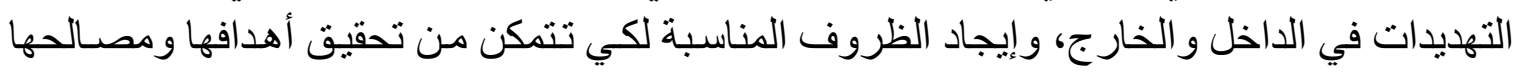

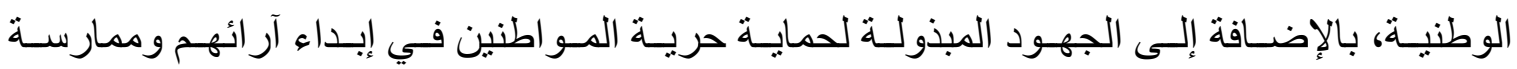

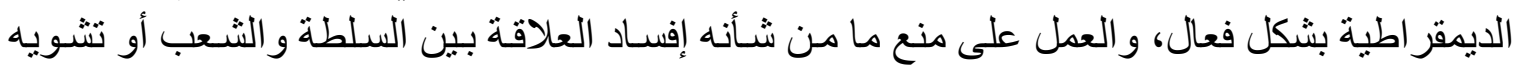

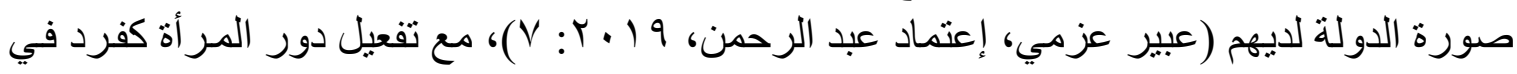

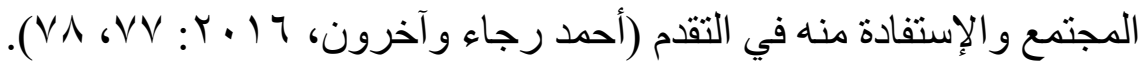

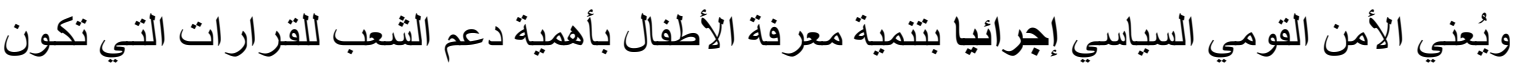

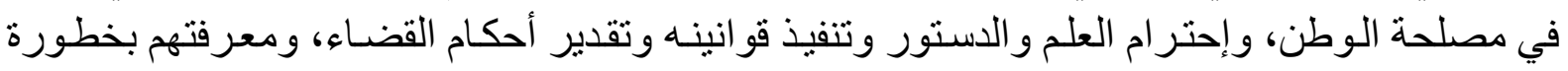

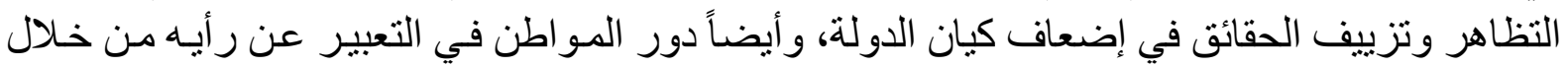

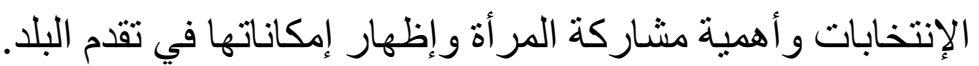

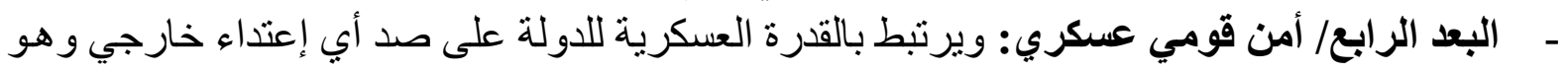

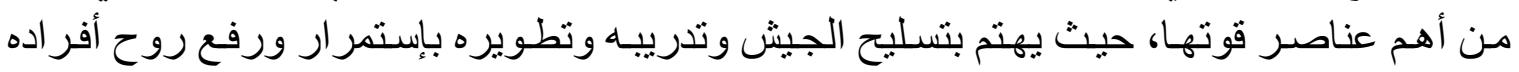

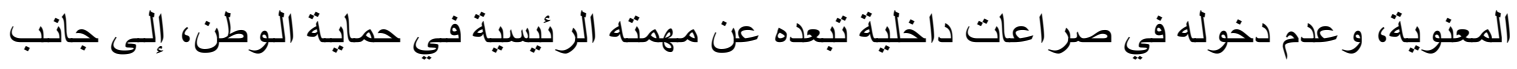

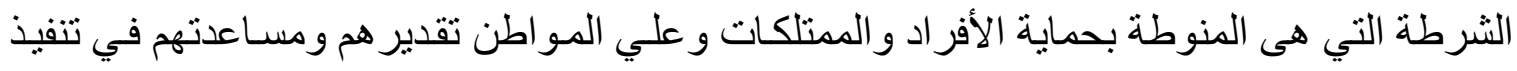

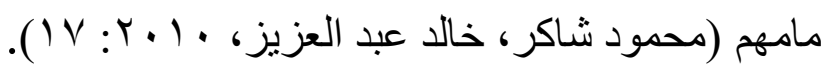

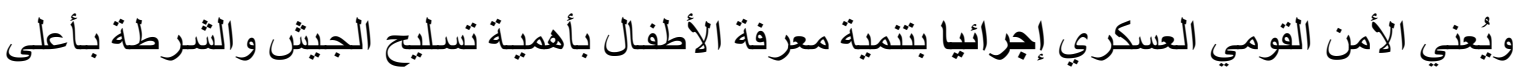

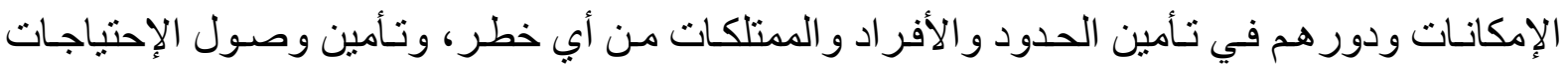

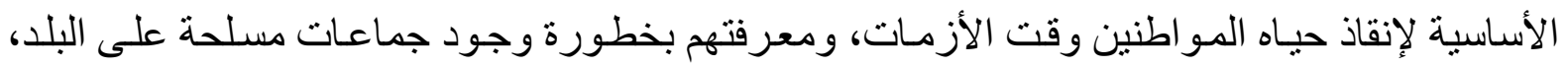

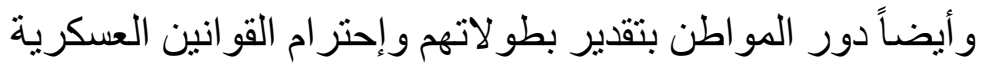

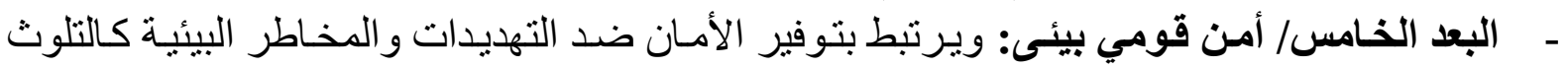
البيئي و الذي يمكن أن ينعكس سلباً على الأمن، ويستهدف وئه حماية المو ارد الطبيعية كالطاقة و التي تُفرِز

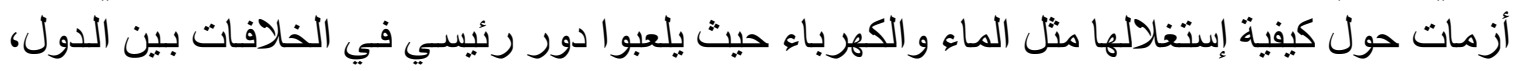

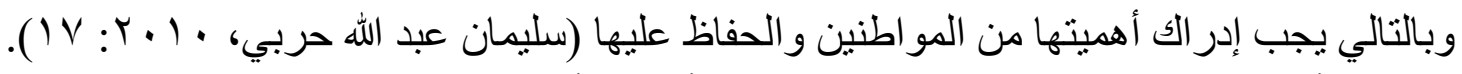
ويُعني الأمن القومي البيئي إجرائيا بتنمية معرفة الأطفال بأهمية حفاظ الدولة الدينة على البيئة بعدم البنـاء

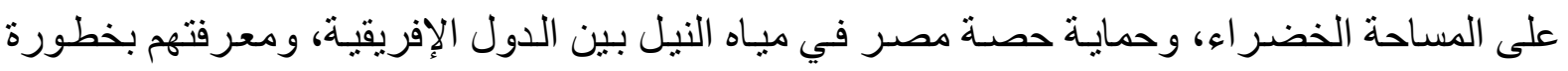

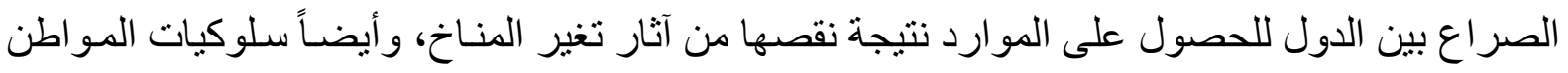
اللازمة لحماية بلده من آثار التلوث ونوفير إستهلاك الكهرباء و المياه وإستخدام الطاقة الثمسية كبديل آمن 
تنثير الباحثة إلى أن أبعاد ومفاهيم الأمن القومي متداخلة ومتر ابطة فكل منها يؤثر في الآخر سواء

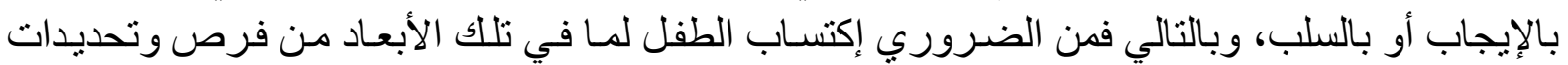

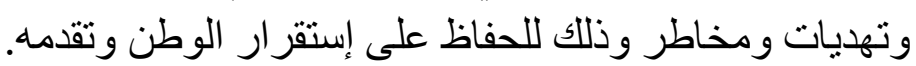

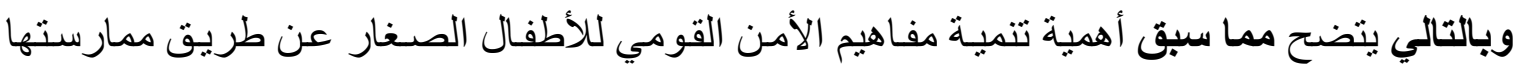

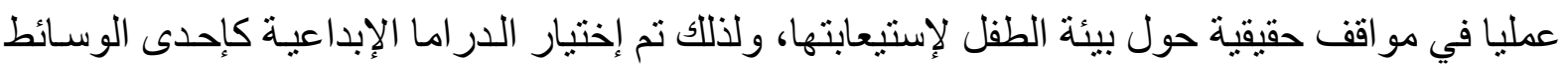

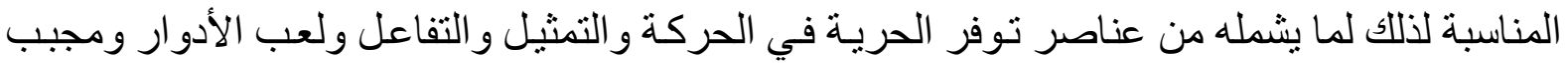

\section{خطوات وإجراعات البحث:}

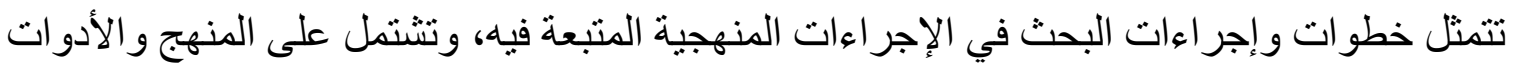

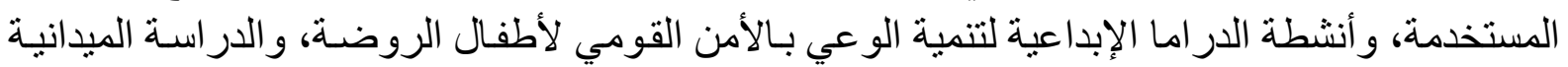
وكذلك الأساليب الإحصائية لمعالجة البيانات. أولاً: منهج البحث: البحالب الاحث:

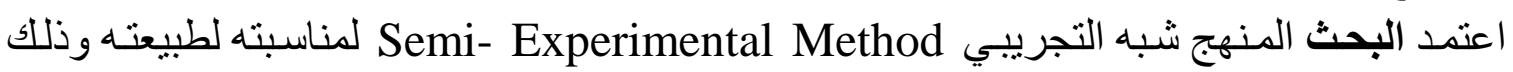

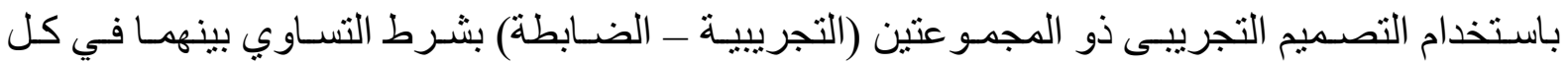

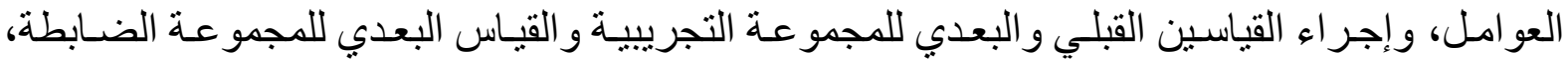

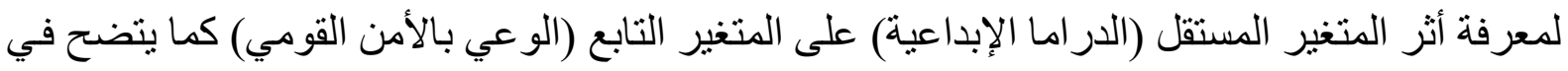

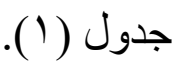

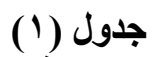

يوضح التصميم التجريبى والقياسات القبلية والبعدية والتتبعي لمجموعات البحث.

\begin{tabular}{|c|c|c|}
\hline المجموعة الضابطة & المجموعة التجريبية & القباسات المستخدمة الدارسة \\
\hline$x$ & $\sqrt{ }$ & القياس القبلى \\
\hline$\sqrt{ }$ & $\sqrt{ }$ & برنامج الروضة \\
\hline$x$ & $\sqrt{ }$ & برنامج أنثطة الدراما الإبداعية المقترح \\
\hline$\sqrt{ }$ & $\sqrt{ }$ & القياس البعدى \\
\hline$x$ & $\sqrt{ }$ & القياس التببعي \\
\hline
\end{tabular}

ثانياً: مجتمع وعينة البحث

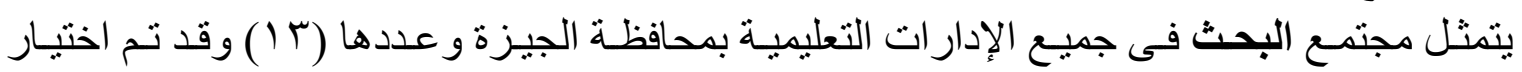

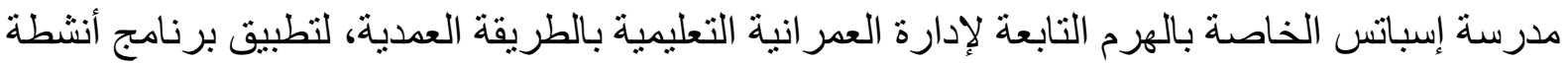

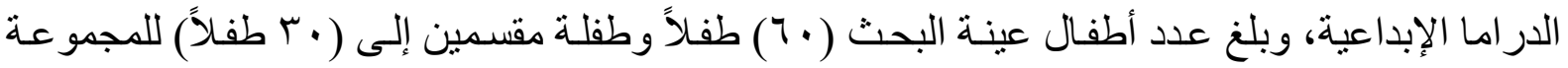

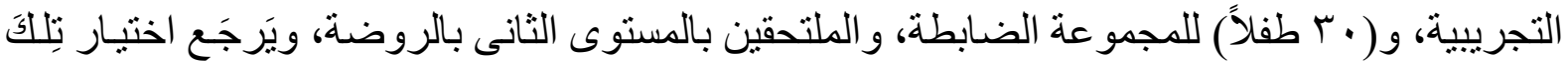

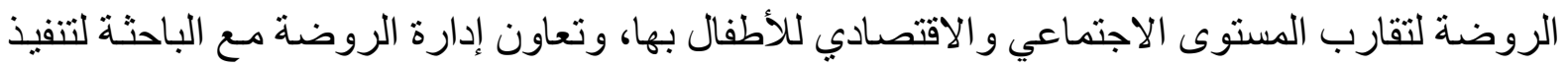

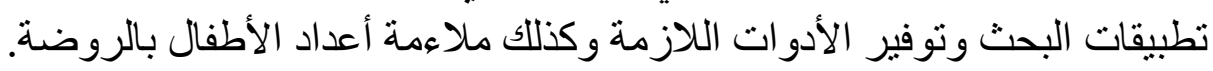

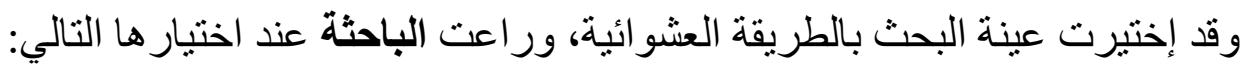
- 
- أن يكونوا من الملتزمين بالحضور في الروضة.

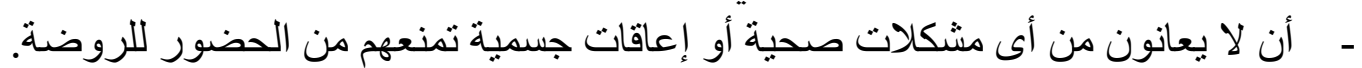
ت تجانس العينة

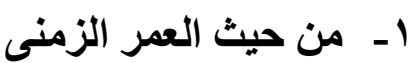

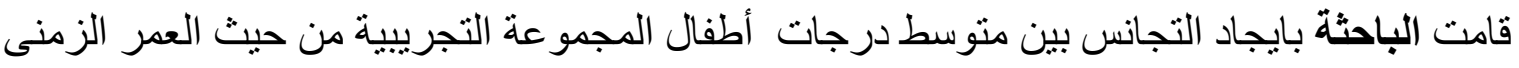

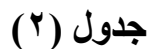

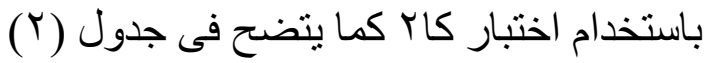
التجانس بين أطفال المجموعة التجريبية من حيث العمر الزمنى

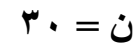

\begin{tabular}{|c|c|c|c|c|c|}
\hline \multicolumn{2}{|c|}{ حدود الدلالة } & \multirow[t]{2}{*}{ درجة حرية } & \multirow[t]{2}{*}{ مستوى الدلالة } & \multirow[t]{2}{*}{ SL } & \multirow[t]{2}{*}{ المتفيرات } \\
\hline$\because .0$ & $\because .1$ & & & & \\
\hline$V_{.} . \Lambda$ & $11 . \%$ & $\bar{r}$ & غير دالة & Y.OTT & العمر الزمنى \\
\hline
\end{tabular}

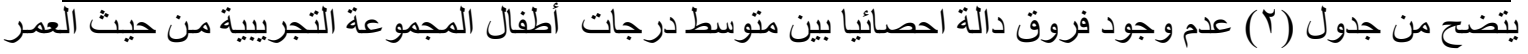
الزمنى مما يشير الى تجانس هؤ لاء الأطفال.

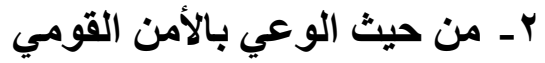

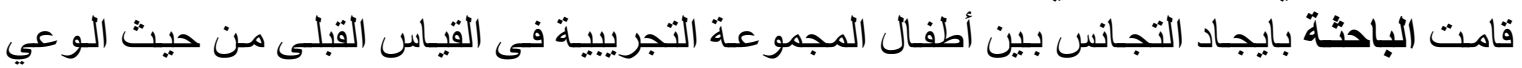

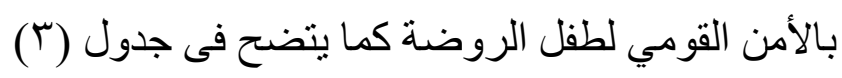

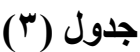
التجانس بين أطفال المجموعة التجريبية فى القياس القبلى من حيث الوعي بالأمن القومي لطفل الروضة

\begin{tabular}{|c|c|c|c|c|c|}
\hline \multicolumn{2}{|c|}{ حدود الدلالة } & \multirow{2}{*}{ درية } & \multirow{2}{*}{ مستولة } & \multirow[t]{2}{*}{ SL } & \multirow[t]{2}{*}{ المتغيرات } \\
\hline$\because .0$ & $\because .1$ & & & & \\
\hline r.A & 7.7 & 1 & غير دالة & T.rT & البعد الإقتصادي \\
\hline$r . \wedge$ & 7.7 & 1 & غير دالة & $1 . Y$ & البعد الإجتماعي \\
\hline$r . \wedge$ & 7.7 & 1 & غير دالة &. $.1 \% \pi$ & البعد السياسي \\
\hline$r . \wedge$ & 7.7 & 1 & غير دالة & r.ITr & البعد العسكري \\
\hline 7 & 9.5 & r & غير دالة & $\cdot \wedge$ & البعد البيئي \\
\hline $1 Y .7$ & 17.1 & 7 & غير دالة & 11.97 & الارجة الكلية \\
\hline
\end{tabular}

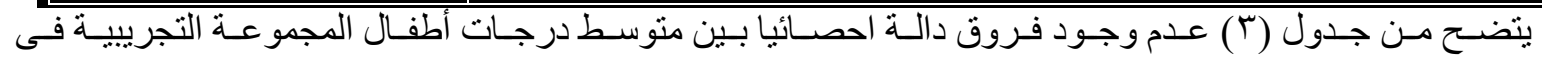

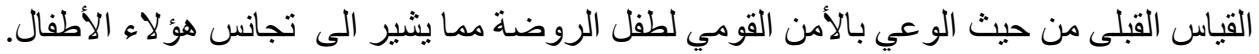

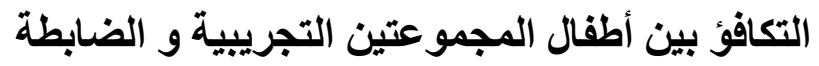

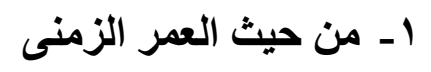
قامت الباحثة بايجاد دلالة الفروق بين منوسط درجات أطفال المجمو عتين التجرييية و الضـابطة فى الزي

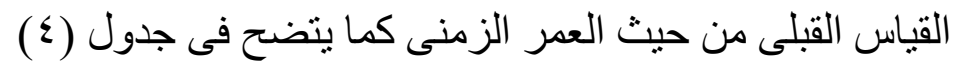




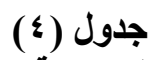

التكافؤ بين أطفال المجموعتين التجريبية والضابطة من حيث العمر الزمنى

7. = ن

\begin{tabular}{|c|c|c|c|c|c|c|}
\hline \multirow[t]{2}{*}{ مستوى الدلالة } & \multirow[t]{2}{*}{ 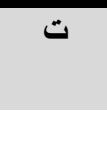 } & \multicolumn{2}{|c|}{ ن المجموعة الضابطة } & \multicolumn{2}{|c|}{ 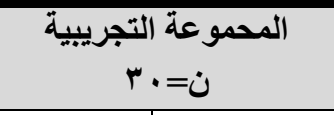 } & \multirow[t]{2}{*}{ المتغيرات } \\
\hline & & $r \varepsilon$ & $r_{p}$ & $1 \varepsilon$ & p & \\
\hline غير دالة & $\cdot . \vee \wedge 9$ & 1.90 & $\vee \wedge . \varepsilon r$ & $1 . \cdot r$ & $\vee \wedge .77$ & العمر الزمنى \\
\hline
\end{tabular}

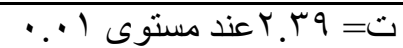

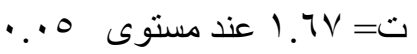

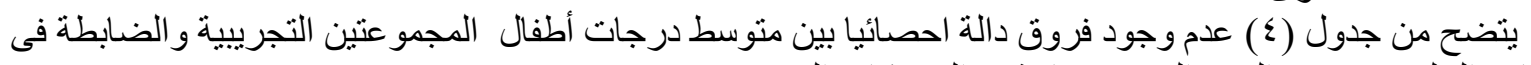

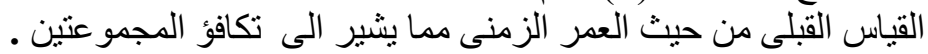

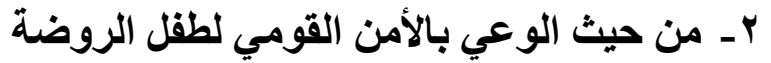

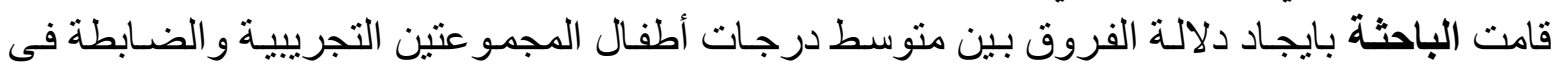

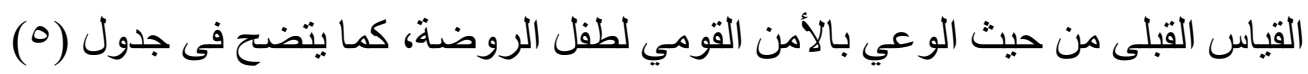

(•) جدول

التكافؤ بين أطفال المجموعتين التجريبية والضابطة من حيث الوعي بالأمن القومي لطفل الروضة

7. = ن

\begin{tabular}{|c|c|c|c|c|c|c|}
\hline \multirow[t]{2}{*}{ مستوى } & \multirow[t]{2}{*}{ ت } & \multicolumn{2}{|c|}{ المجموعة الضابطة } & \multicolumn{2}{|c|}{ 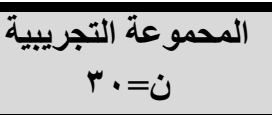 } & \multirow[t]{2}{*}{ المتغيرات } \\
\hline & & $r_{\varepsilon}$ & $r_{p}$ & $\varepsilon$ & p & \\
\hline غير دالة & $1 . Y 0 \leqslant$ & $\cdot . V \mu$ & V.orr &.$\leqslant \vee q$ & V.rr & البعد الإقتصادي \\
\hline غير دالة &. .579 & 1.0 & $V . V$ &.$\leqslant 9$ & $v .7$ & البعد الإجتماعي \\
\hline غير دالة &.$r \wedge 1$ & $. \wedge / \mu$ & $V_{.} \varepsilon$ & $.0 \cdot V$ & $V . \leqslant 7$ & البعد السياسي \\
\hline غير دالة & $\because r q 1$ & 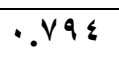 & $V . V$ &..$\leq 9$ & V.7r & البعد العسكري \\
\hline غير دالة & 1.171 & 1.44 & $\Lambda . Y 4$ & $\because \vee \wedge \leq$ & V.9r & البعد البيئي \\
\hline غير دالة & $1 . \mu r \varepsilon$ & r.IV & ५^. & $1 . \leqslant Y$ & rV.q4 & الارجة الكلية \\
\hline
\end{tabular}

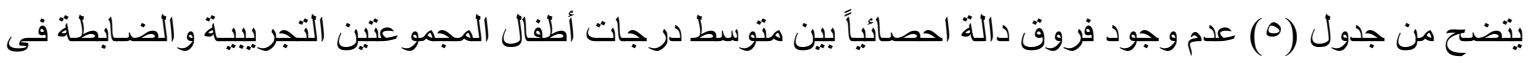

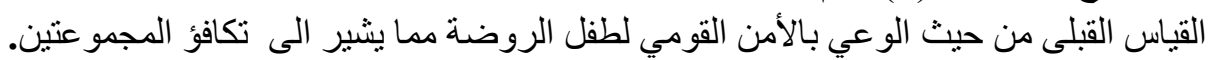

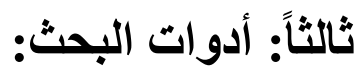

تتمثل أدو ات البحث في:

ا ـ ـاستمارة إستطلاع الر أب لتحديد أبعاد الوعي بالأمن القومي المناسبة لأطفال الروضة. [إعداد/ الباحثة]

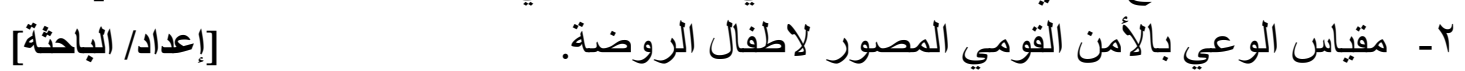
r- بطاقة ملاحظة آدائية لممارسات أطفال الروضة الموري المرتبطة بمدى الوعي بالأمن القومي.

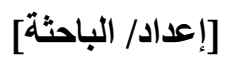

عـ - برنامج أنشطة در اما إبداعية لتنمية الوعي بالأمن القومي لأطفال الروضة. [ [إعداد/ الباحثة]

وفيما يلي وصف تفصيلي لهذه الأدوات:

1 - استمارة إستطلاع الرأي لتحديد أبعاد الوعى بالأمن القومى المناسبة لأطفال الروضة.

[إعداد/ الباحثة] 


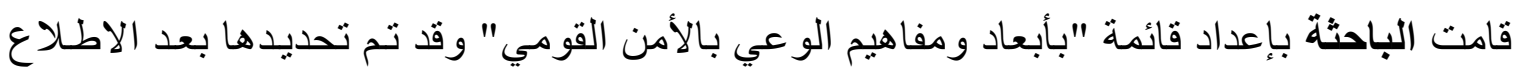

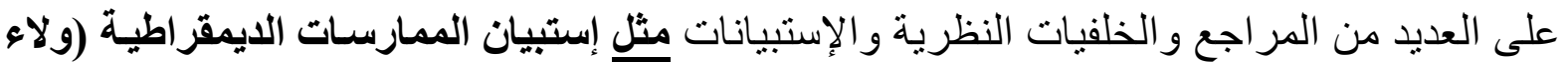

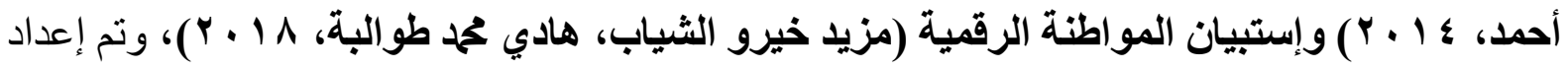

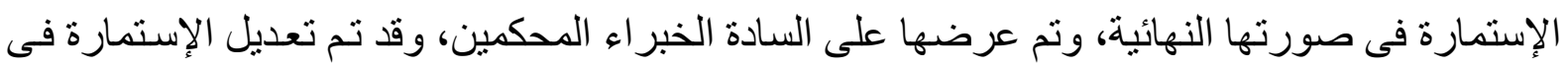

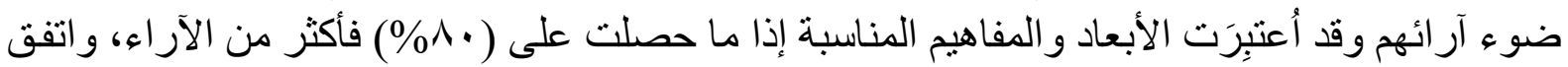

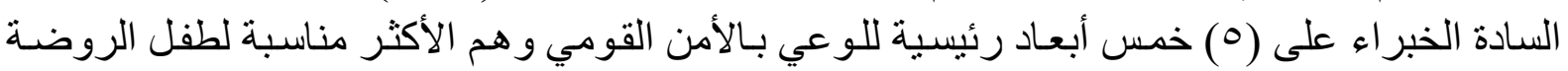

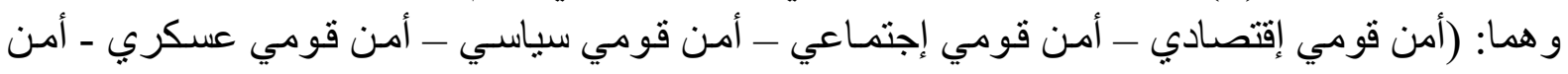
قومي بيئي).

[إعداد/ الباحثة]

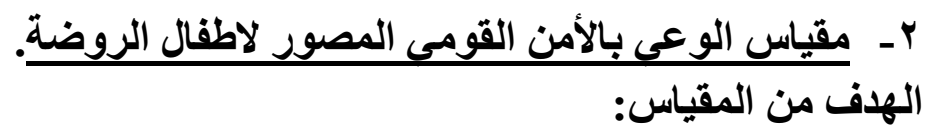

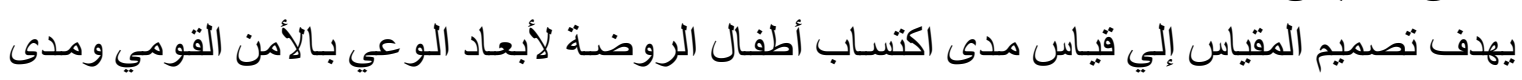

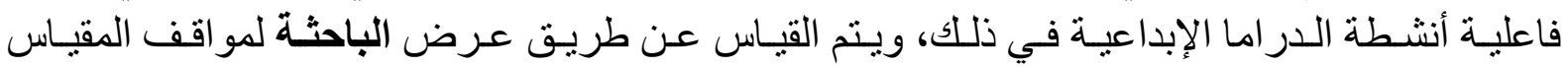

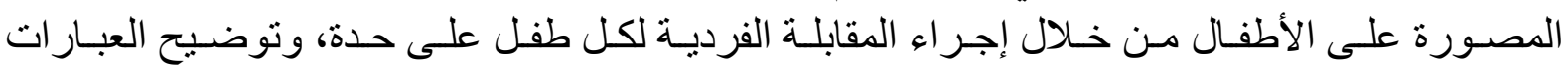

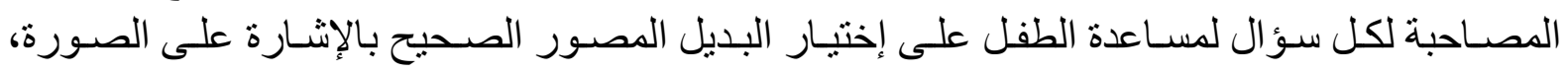
ويتكون المقياس من (0ب سؤ ال) مقسمين على الأبعاد التالية:

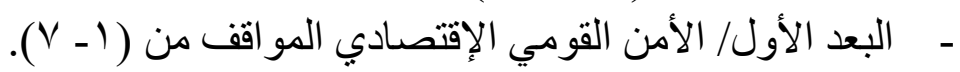

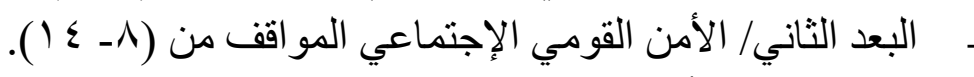

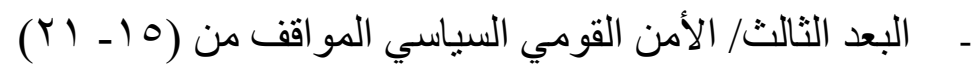

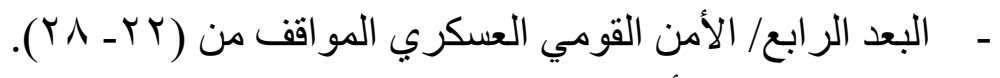

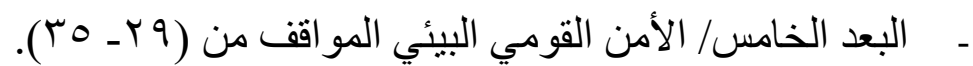

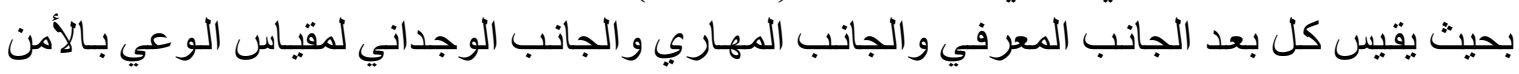

$$
\text { خطوات تصميم المقياس: الأطفال الروضة. }
$$

( ) الإطـلاع على البحـوث و الدر اسـات السـابقة ذات الصـلة بموضـوع البحـث للاستفادة منهـا فى إعداد المقياس الحالي.

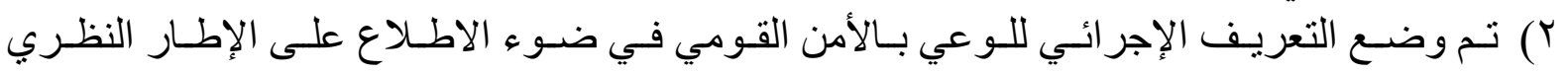

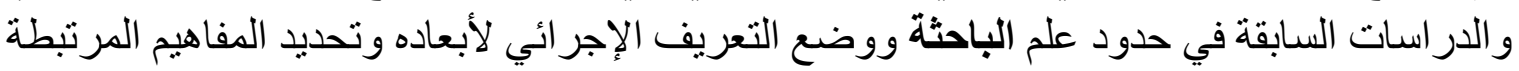

بها وكيفية قياسها إجر ائياً.

ب) قامت الباحثة بالإطلاع على عدد من المقاييس التي ساهمت بدور ها في إعداد مقياس الوعي بـالأمن

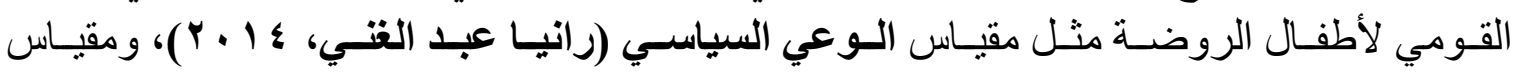

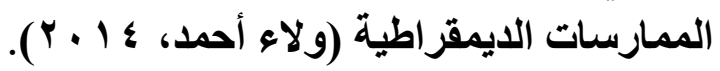

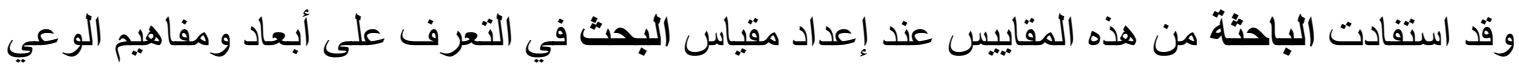

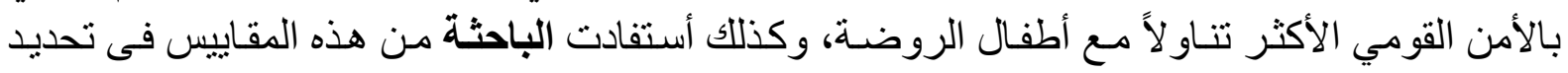

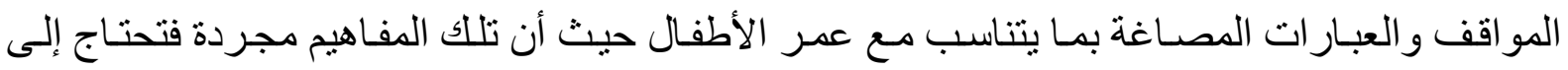

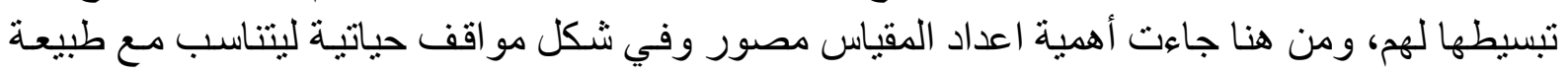

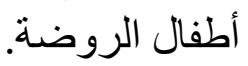


ع) راعت الباحثّة في تصميم المقياس أن تكون بنوده مرتبطة بيئة الأطفال وأن تتناول الدجالات الثناث

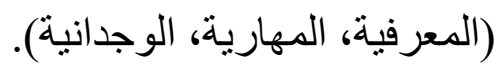

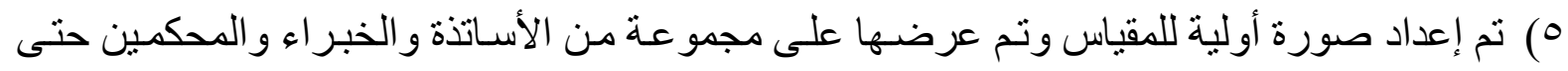

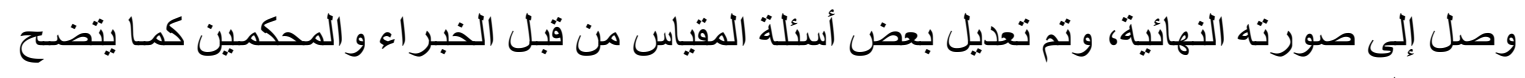

في جدول (7): (7)

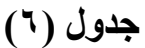

تعديل بعض أسئلة مقياس الوعي بالأمن القومي وفقاً لآراء المحكمين

\begin{tabular}{|c|c|c|}
\hline الموقف بعد التعديل & الموقف قبل التعديل & الموقف \\
\hline 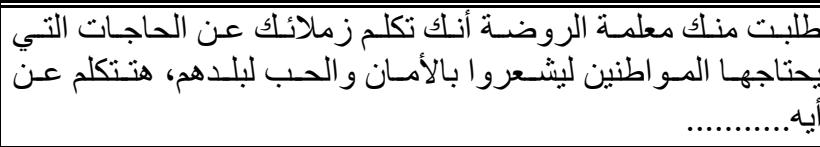 & أنت مواطن تريد أن تثعر بالأمان هتحتاج ايـ.... & $\bar{r}$ \\
\hline 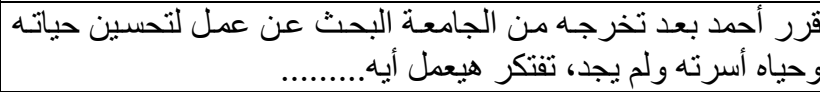 & أنت مواطن تحتاج لتحسين دخلك هتفكر إزاي........ & $\mathrm{v}$ \\
\hline 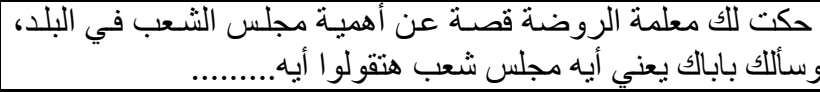 & 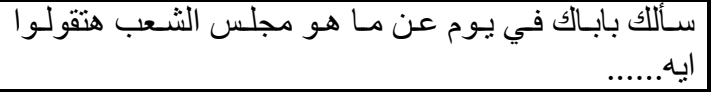 & 17 \\
\hline
\end{tabular}

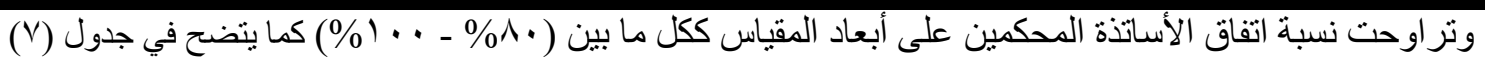

جدان (V)

يوضح النسبة المئوية لاتفاق آراء المحكمين على أبعاد مقياس الوعي بالأمن القومي المصور لأطفال الروضة

\begin{tabular}{|c|c|c|}
\hline النسبة المئوية & الأبعاد & م \\
\hline$\%^{\wedge}$. & الأمن القومي الإقتصادي & $T$ \\
\hline$\% 1 \ldots$ & الأمن القومي الإجتماعي & $\bar{r}$ \\
\hline$\% 9$ & الأمن القومي السياسي & $\Gamma$ \\
\hline$\% 1 \ldots$ & الأمن القومي العسكري & $\varepsilon$ \\
\hline$\% 1 \ldots$ & الأمن القومي البيئي & 0 \\
\hline
\end{tabular}

تعليمات المقياس:

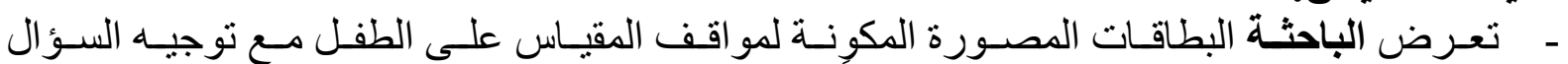

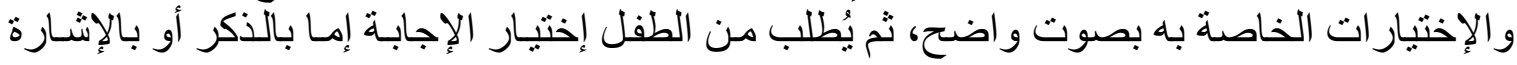
على الصورة المعبرة عن إجابته.

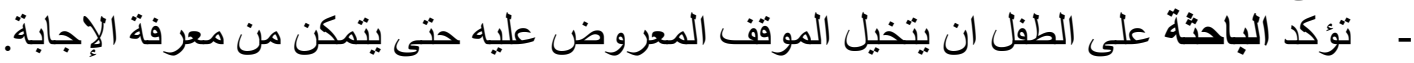

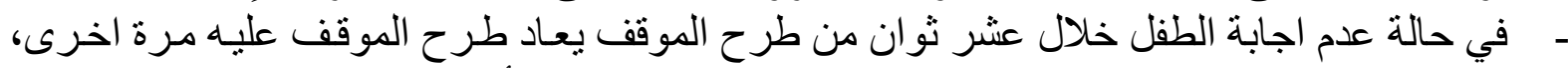

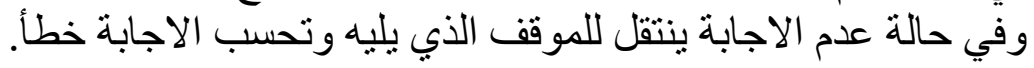

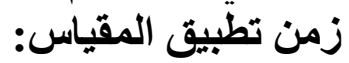

قامت الباحثة بتحديد (· ب دقيقة) لكل طفل، وذللك كمتوسط للزمن الذى استغرقه الأطفال في التجربة

الاستطلاعية.

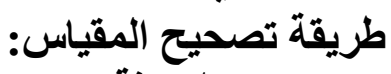

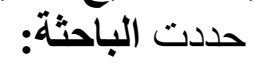

أـ في حالة إختبار الطفل البديل المصور الصحيح من أول مرة تحسب له له (ثلاث درجات).

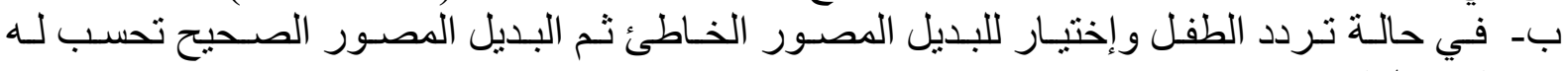

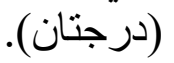

تـ- في حالة إختيار الطفل للبديل المصور الخاطئ تحسب له (درجة واحدة).

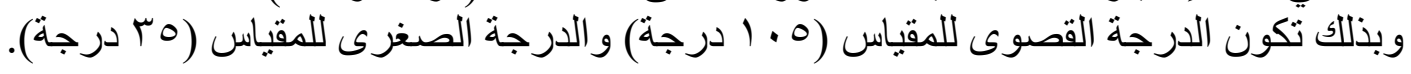


الخصائص السيكومترية لمقياس الوعي بالأمن القومي المصور لأطفال الروضة

قامت الباحثية باجر اء التحليل العاملي الاستكثافى للمقياس بتحليل المكونات الأساسية بطريقة هوتلنج

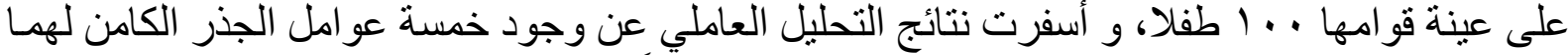

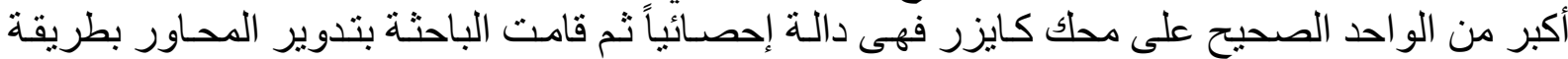

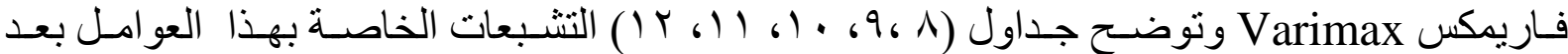

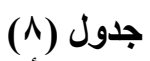

التشبعات الخاصة بالعامل الأول (البعد الإقتصادي)

\begin{tabular}{|c|c|c|}
\hline التشبعات & العبارة & العبارة \\
\hline 0.89 & قرر المسئولين في البلا أنهر يخصصوا بعض الأموال لتوفير حياه كريمة وآمنة للمواطنين، تفتكر هيعموا أيه....... & $\overline{1}$ \\
\hline 0.88 & 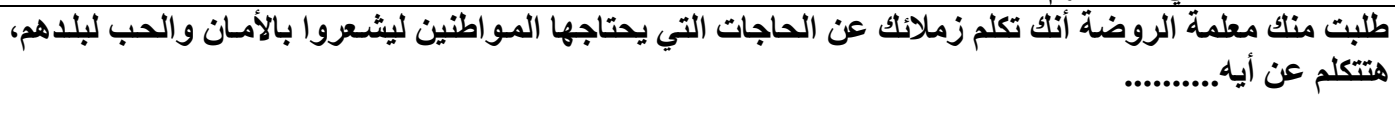 & r \\
\hline 0.87 & 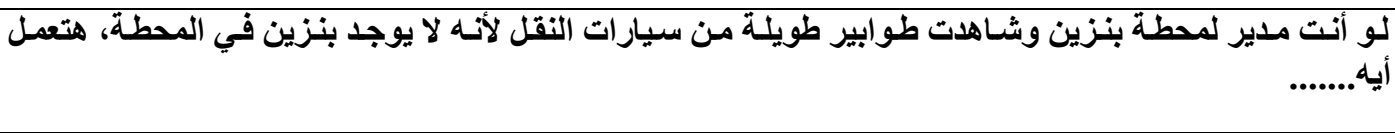 & 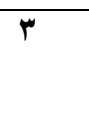 \\
\hline 0.86 & أيه................. معلمة الروضة قصة عامل في مصنع كبير ولا يعجبه المرتب الذي يأخذه ليشتري ما يحتاجه، تفتكر هيعمل & 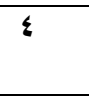 \\
\hline 0.85 & تفتكر هيعمل صايه......... فصنع لإنتاج علب اللبن بنقص شديد في الكميات المطلوبة بالسوق وعلثان يحافظ على وطنه، & o \\
\hline 0.84 & في يوم شاهلت مجموعة من الأشخاص يرسمون ويحفرون على سور كوبري جليد للسيارت، هتعمل أيه...... & 7 \\
\hline 0.72 & قرر أحمد بعد تخرجه من الجامعة البحث عن عمل لتحسين حياته وحياه أسرته ولم يجد، تفتكر هيعمل أيه......... & $\mathrm{v}$ \\
\hline$\% 52.21$ & نانبة التباين & \\
\hline 18.27 & الجذر الكامن & \\
\hline
\end{tabular}

يتضح من جدول (^) أن جميع التشبعات دالة إحصائياً حيث قيمة كل منها أكبر من ·؟ ·ـ · على محك جيلفورد.

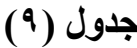

التثبعات الخاصة بالعامل الثاني (البعد الإجتماعى)

\begin{tabular}{|c|c|c|}
\hline التشبعات & العبارة & رقم العبارة \\
\hline 0.86 & 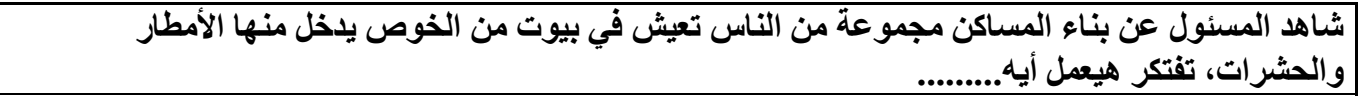 & $\Lambda$ \\
\hline 0.85 & أنه.......... مواطن تعرف أن من حقك أنك تأخذ علاج مناسب في بلدك في أي وقت عندما تحتاج له، أول حاجة هتعلها & 9 \\
\hline 0.85 & 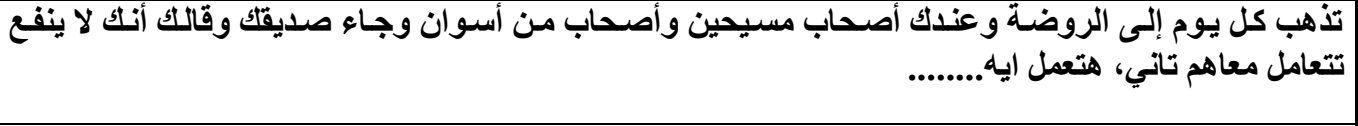 & 1. \\
\hline 0.84 & تقرب الرسم، الروضة عمل معرض إزاي........ لعرض الرسومات التي رسمها زملاثك فيه وتوزيع جوائز، وانت لا تثارك لأكتك لا & 11 \\
\hline 0.83 & طلبت منك معلمة الروضة تشثيل دور أب في مسرحية لتوعية زملائك من الزيادة السكانية، هتعل أيه......... & Ir \\
\hline 0.82 & في يوم وأنت راجع من الروضة وجلت جارتك راجعة من السوق وفي يدها شنط كثير هتعمل ايه.......... & 14 \\
\hline 0.80 & 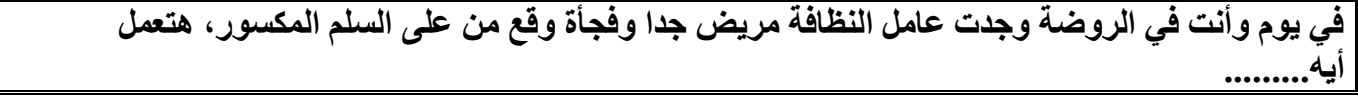 & $1 \leqslant$ \\
\hline$\% 16.33$ & نسبة التباين & \\
\hline 5.71 & الجذر الكامن & \\
\hline
\end{tabular}

يتضح من جدول (9) أن جميع النتبعات دالة إحصائياً حيث قيمة كل منها أكبر من ·؟ · · على محك جيلفورد. 


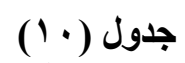

التثبعات الخاصة بالعامل الثالث (البعد السياسي)

\begin{tabular}{|c|c|c|}
\hline التشبعات & العبارة & رقم العبارة \\
\hline 0.82 & فوجئت في يوم أن في قرار من رئيس البلا يمنع نزول المواطنين في الثـارع علثـان في خطر على & 10 \\
\hline 0.81 & هتقولو أيه............. الروضة قصة عن أهمية مجلس الثعب في البلد، وسألك باباك يعني أيه مجلس شعب & 17 \\
\hline 0.80 & شاهلت فيلم لموظف بنك سرق أموال خزنة البنك كلها، تفتكر هيتعاقب إزاي ........ . . & IV \\
\hline 0.80 & هتعمل رئيس الحي إلي أنت عايش فيه إنشاء مبني جديد لمدرستك لينقلكم فيه والقرار ده ضايقك جدا، & 11 \\
\hline 0.70 & 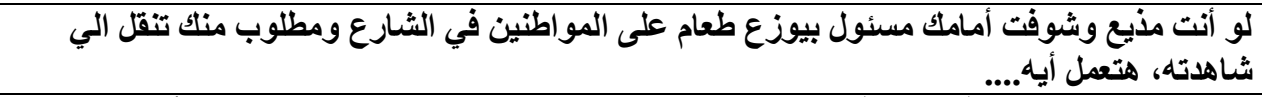 & 19 \\
\hline 0.38 & 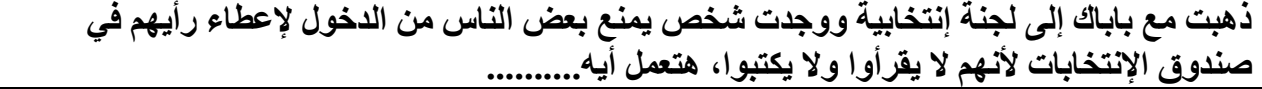 & $r$. \\
\hline 0.32 & 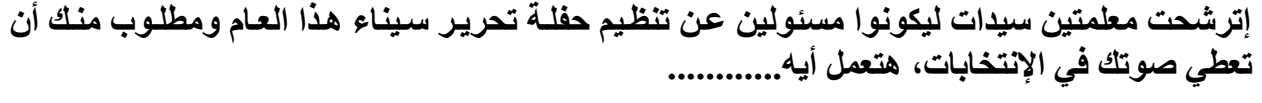 & ri \\
\hline$\% 10.52$ & نسبة التباين & \\
\hline 3.68 & الجذر الكامن & \\
\hline
\end{tabular}

يتضح من جدول (· ( ) أن جميع التشبعات دالة إحصائياً حيث قيمة كل منها أكبر من ·؟ · · على محك جيلفورد.

جدول (1)

التشبعات الخاصة بالعامل الرابع (البعد العسكري)

\begin{tabular}{|c|c|c|}
\hline التثبعات & العبارة & رقم العبارة \\
\hline 0.81 & 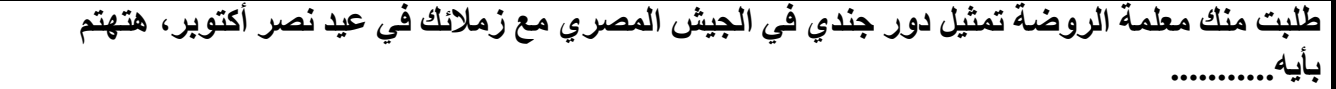 & rY \\
\hline 0.79 & 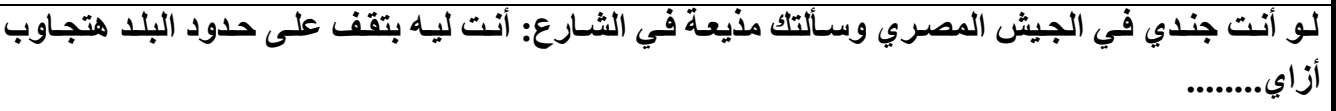 & $r r$ \\
\hline 0.79 & 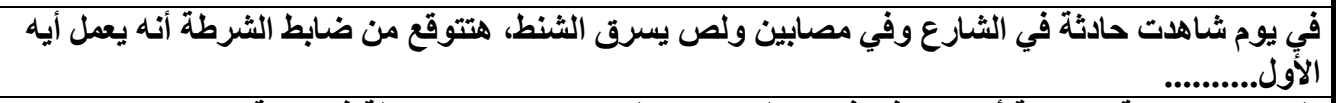 & $Y \varepsilon$ \\
\hline 0.77 & 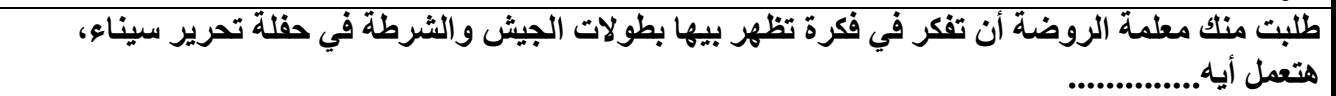 & ro \\
\hline 0.63 & تخيل لو جيرانك في العمارة الي أنت ساكن فيها معاهم أسلحة علشان يحموا بيها أنفسهم، هتفكر أزاي.......... & Y \\
\hline 0.59 & 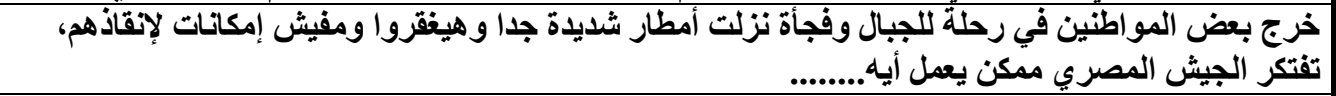 & YV \\
\hline 0.57 & لو في يوم جاء لأخوك الكبير طلب ليذهب للجيش ليقوم بالخذمة الوطنية لبلده، هتعمل أيه........ & $r \wedge$ \\
\hline \%8.28 & نسبة التباين & \\
\hline 2.89 & الجذر الكامن & \\
\hline
\end{tabular}

يتضح من جدول (1 (1) أن جميع التشبعات دالة إحصائياً حيث قيمة كل منها أكبر من ·؟ · · على محك جيلفورد. 
جدول (r)

التشبعات الخاصة بالعامل الخامس (البعد البيئي)

\begin{tabular}{|c|c|c|}
\hline التشبعات & 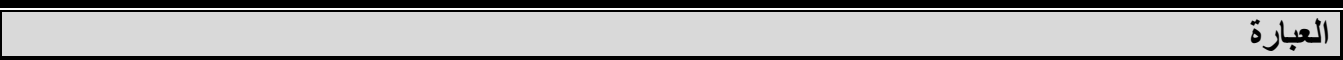 & رقم العبارة \\
\hline 0.74 & 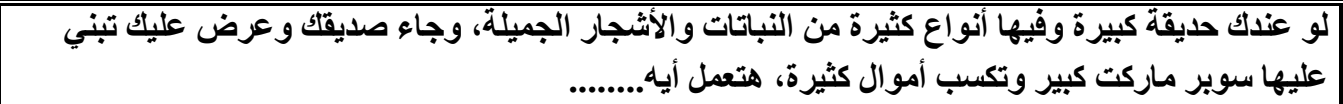 & rq \\
\hline 0.74 & طلبت منك معلمة الروضة أن ترسم رسمة تبين فيها إثتراك الدول الإفريقية في نهر النيل، هترسم إيه..... & $r$. \\
\hline 0.62 & من المواطنين يريدون مانت شتراء الخبز، هتعمل ايه....... للمخبز وجلت نقص في كمية الخبز الموجودة ويوجد طابور طويل & $r_{1}$ \\
\hline 0.36 & 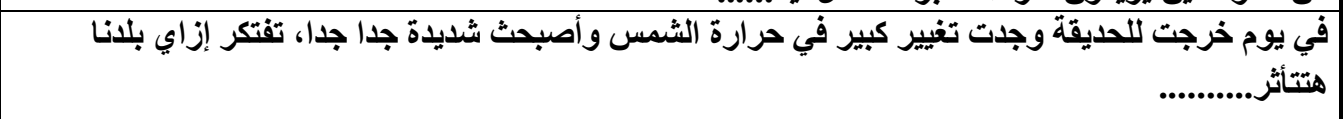 & TY \\
\hline 0.34 & لو لوعل أيلك في.... البيت كمية كبيرة من القمامة وعايز ترميها بس لازم تحافظ على البيئة في بلاك من التلوث، & $r r$ \\
\hline 0.30 & أنت تعيش في عمارة سكنية يقطع النور فيها بإستمرار و السكان متضايقين جدا، هتعمل أيه.......... & $r \varepsilon$ \\
\hline 0.30 & لو عذك مزرعة فواكه كبيرة وتريد ان توفر المياه وانت بتسقيها كل يوم علشان بلدك، هتعمل أيه........ & ro \\
\hline \%3.38 & نسبة التباين & \\
\hline 1.18 & ر الكامن & \\
\hline
\end{tabular}

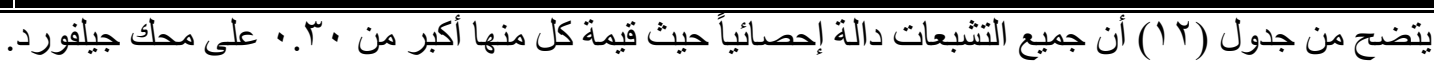

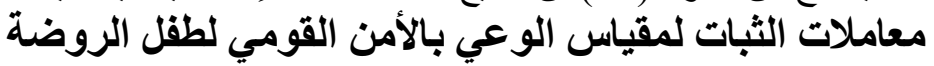

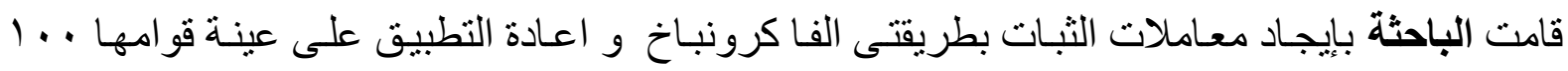

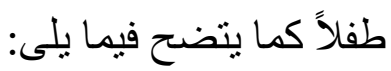

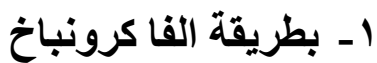

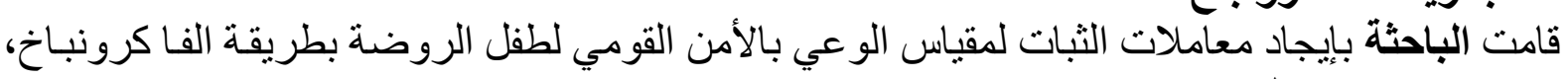
كما يتضح في جدول (Ir)

\section{جلول (r)}

معاملات الثبات لمقياس الوعي بالأمن القومي لطفل الروضة

بطريقة الفا كرونباخ الأخن

\begin{tabular}{|c|c|}
\hline معاملات الثبات(الفا) & الأبعاد \\
\hline .90 & البعد الإقتصادي \\
\hline .9 . & البعد الإجتماعي \\
\hline. .97 & البعد السبياسي \\
\hline.$\wedge 0$ & البعد العسكري \\
\hline.$\wedge \wedge$ & البعد البيئي \\
\hline $.9 \mathrm{~V}$ & الارجة الكلية \\
\hline
\end{tabular}

يتضح من جدول (r I ) أن قيم معاملات الثبات مرتفعة مما بدل على ثبات المقياس.

r- بطريقة اعادة التطبيق

قامت الباحثة بإيجاد معاملات الثبات بطريقة اعادة التطبيق بفاصل زمل زمنى قدره أسبو عان على عينـة

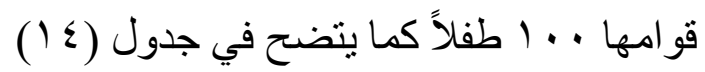




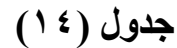

معاملات الثبات لمقياس الوعي بالأمن القومي لطفل الروضة

بطريقة اعادة التطبيق الأون

\begin{tabular}{|c|c|}
\hline معاملات الثبات & الأبعاد \\
\hline 9.97 & البعد الإقتصادي \\
\hline. .94 & البعد الإجتماعي \\
\hline. $.9 \mathrm{~V}$ & البعد السياسي \\
\hline$\therefore 9$. & البعد العسكري \\
\hline 9.91 & البعد البيئي \\
\hline $9.9 \leqslant$ & الارجة الكلية \\
\hline
\end{tabular}

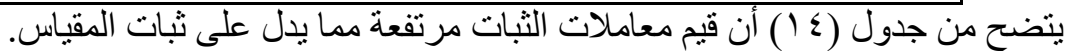

وفيما يلى عرض لبعض مواقف مقياس الوعي بالأمن القومي المصور لأطفال المال الروضة

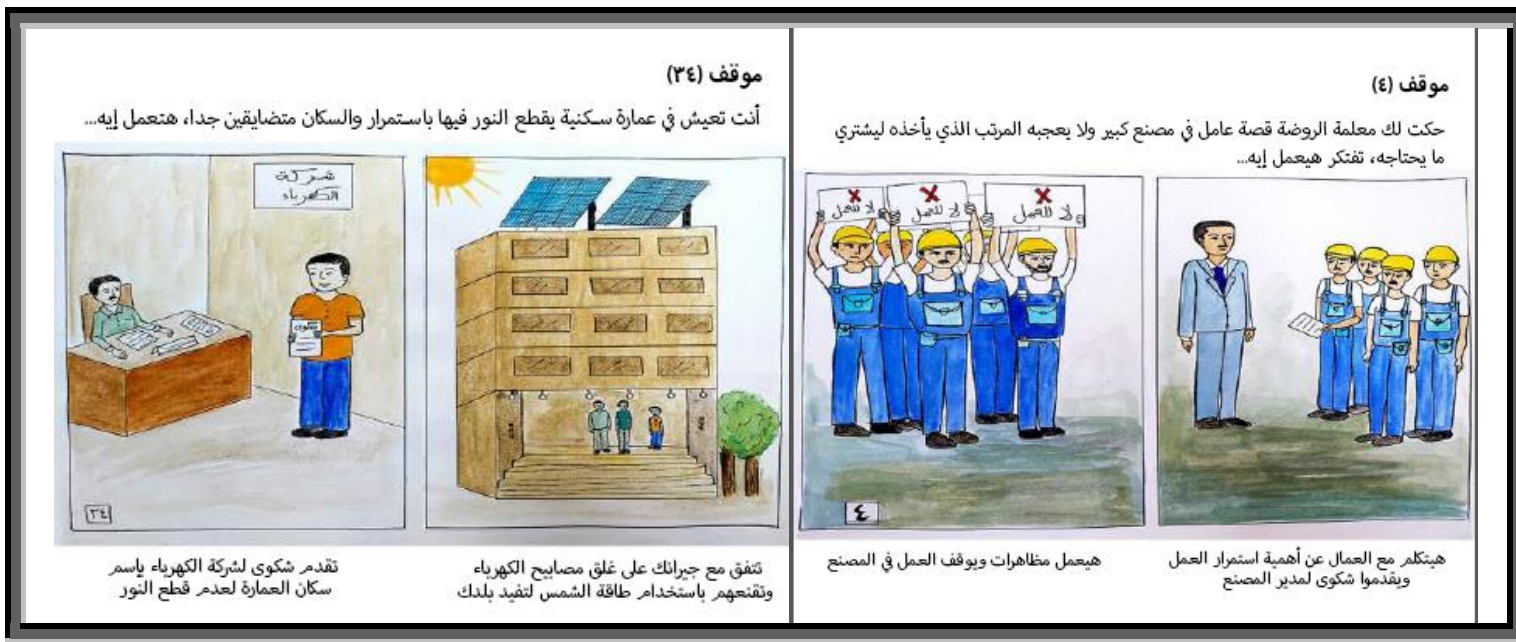

r- بطاقة ملاحظة آدائية لممارسات أطفال الروضة المرتبطة بمدى الوعى بالأمن القومى. [إعداد/ الباحثة:

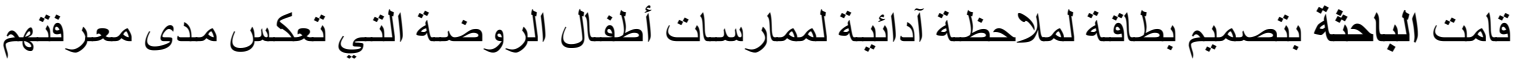

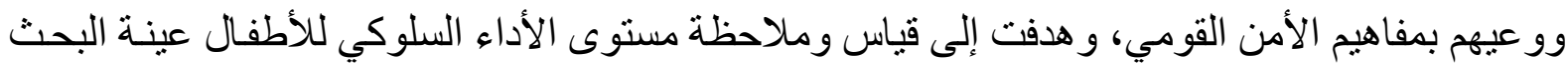

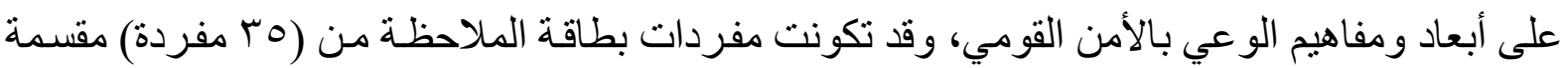
كالتالي:

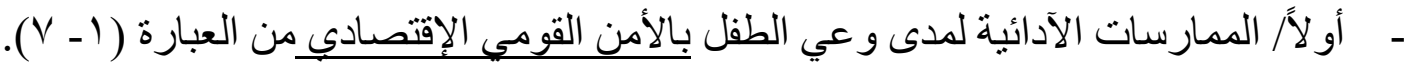

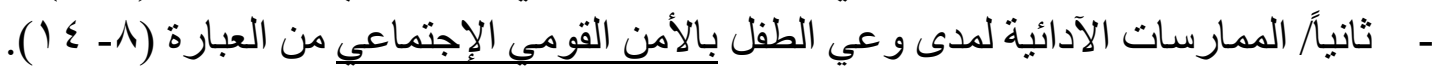

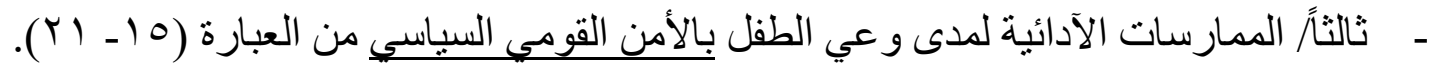

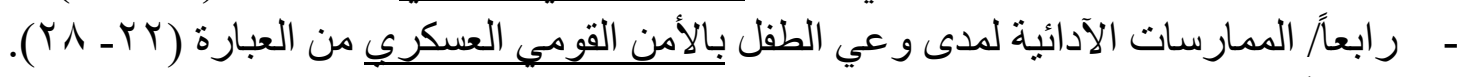

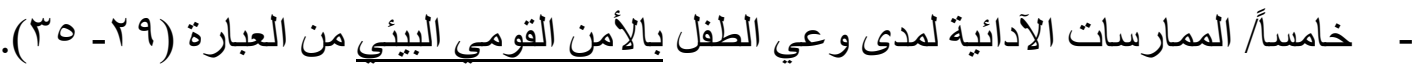
خطوات تصميم بطاقة الملاحظة:

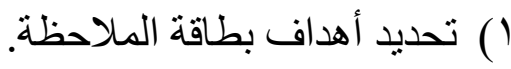

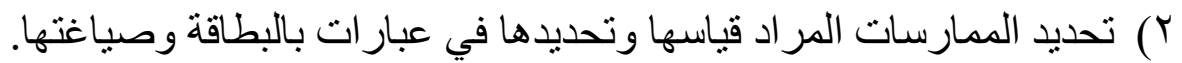

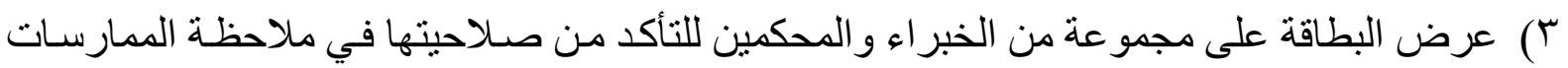
الآدائية للأطفال. ع) وقد راعت الباحثة وضوح العبار ات ودقتها في وصف السلوك الآدائي المر اد ملاحظته. 
0) حساب صدق وثبات بطاقة الملاحظة، وبناء على ذلك قامت الباحثة بالتالي:

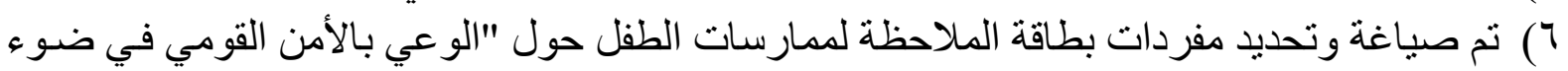
المجالات الثلاثة (المعرفية، الوجدانية، المهارية).

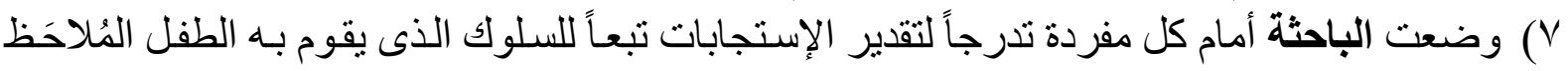

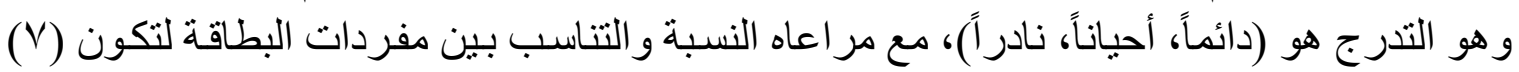

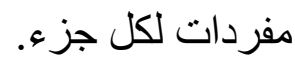

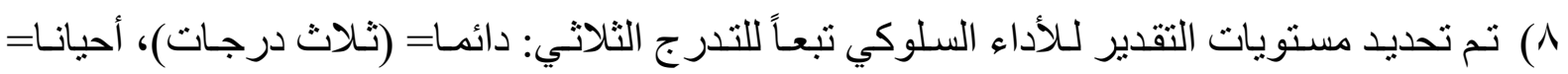

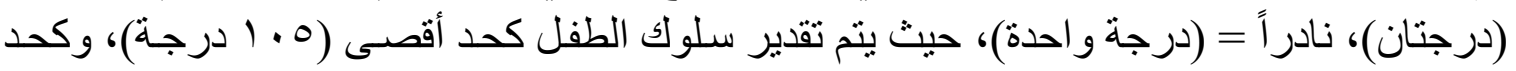

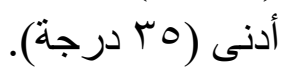
9) قامت كلاً من الباحثة و والمعلمـات المسـاعدات بملاحظة ممارسـات الطفل الآدائية قبل و أثناء وبعد ممارستهم لأنشطة الدر اما الإبداعية. الخصائص السيكومترية لبطاقة ملاحظة آدائية لممارسات أطفال الروضة المرتبطة بمدئة الوعي بالأمن قامت الباحثية باجر اء التحليل العاملي الإستكثافي للبطاقة بتحليل المكونات الأساسية بطريقة هوتلنج

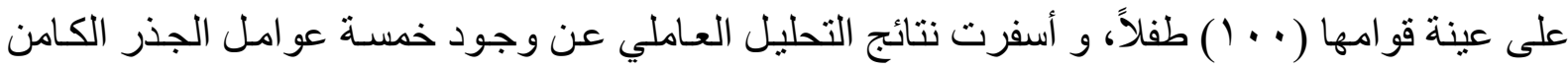

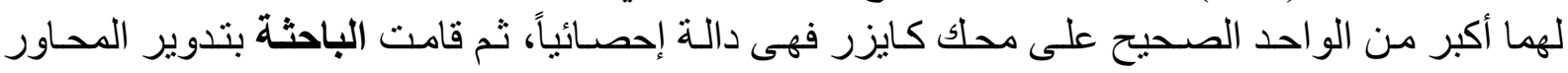

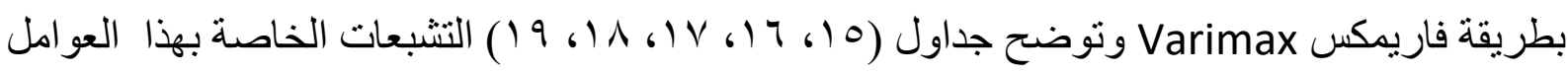
بعد التدوير.

جدول (10) (10)

التثبعات الخاصة بالعامل الأول (البعد الإقتصادي)

\begin{tabular}{|c|c|c|}
\hline التثشبعات & العبارة & رأعبار \\
\hline $\mathbf{0 . 8 9}$ & 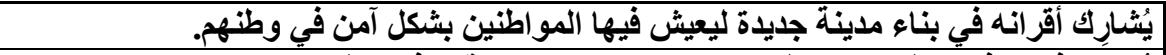 & 1 \\
\hline 0.88 & يُساعِد في توفير الطعام للمو اطنين الفقراء كحق من حقوقهم في وطنهر. & r \\
\hline 0.81 & 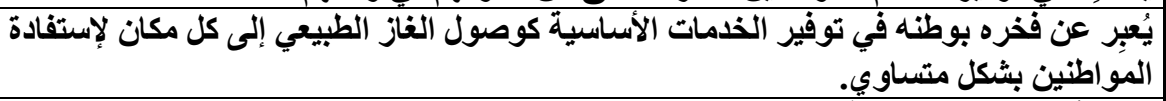 & $r$ \\
\hline 0.77 & 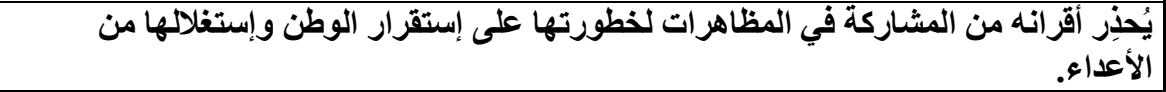 & $\varepsilon$ \\
\hline 0.72 & ليَمنع بقوة إحتكار مواطن للسلع لتحقيق الإستفادة الثخصية على حساب باقي الثُبب. & o \\
\hline 0.65 & يَحمي المباني حوله من التخريب للحفاظ على أموال بلده من الإهدار. & 7 \\
\hline 0.61 & 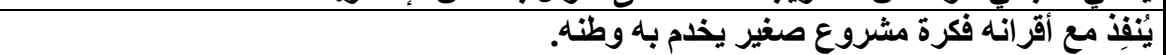 & $\mathrm{v}$ \\
\hline \%42.11 & 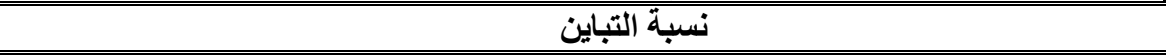 & \\
\hline 25.11 & الجذر الكامن & \\
\hline
\end{tabular}

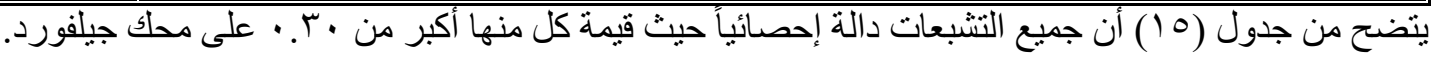




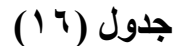

التثبعات الخاصة بالعامل الثاني (البعد الإجتماعي)

\begin{tabular}{|c|c|c|}
\hline التشبعات & العبارة & 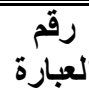 \\
\hline $\mathbf{0 . 8 1}$ & يُعبِر عن حقه في مسكن آمن يعيش فيه مي أسرته في وطنه. & $\Lambda$ \\
\hline 0.80 & يَتَِع الإجراءات المطلوبة لإستخراج بطاقة صحية لأخذ حقه في العلاج داخل وطنه. & 9 \\
\hline 0.79 & يَتجنَب الإستماع إلى الأشخاص الذين يشعلون الفتنة بينه وبين أقرانه في الوطن الواحد. & 1. \\
\hline 0.70 & يُوجِه أقر انه لمساعدة الآخرين وحب الخير لهم حتي لا يثعرون بالغضب في وطنهم. & 11 \\
\hline 0.61 & يَختار أسرة صغيرة العدد للحفاظ على قدرة الدولةة في توزيع الموارد بالعدل بين المواطنين. & Ir \\
\hline 0.60 & المجتَمِم. الآخرين في تعاملاتهـ رغم إختلافه معهم في العـادات والتقاليد للحفـاظ على تماسكك & ir \\
\hline 0.55 & يُشجِع أقر انه للمشاركة في مساعدة المواطنين المتضررين من اي مشكلة تحدث في وطنهم. & $1 \leqslant$ \\
\hline$\% 25.14$ & نسبة التباين & \\
\hline 11.4 & الجذر الكامن & \\
\hline
\end{tabular}

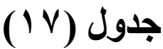

التشبعات الخاصة بالعامل الثالث (البعد السياسي)

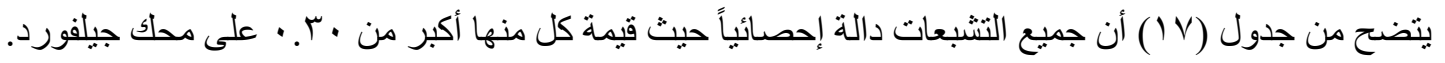

\begin{tabular}{|c|c|c|}
\hline التشبعات & العبارة & 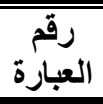 \\
\hline $\mathbf{0 . 7 7}$ & يُو افِقى على قرارات رئيسه التي تحافظ على مصلحة الوطن. & 10 \\
\hline 0.71 & يُشُشاور أقرانه في كيفية الخروج من أي مشكلة في الوطن و إتخاذ قرارات جماعية. & 17 \\
\hline 0.69 & 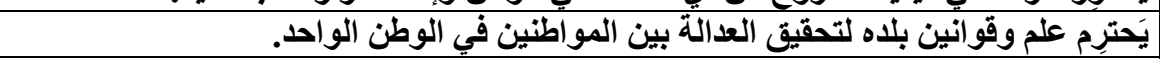 & IV \\
\hline 0.60 & البُعبد. عن رفضه لأي قرار بطريقة سلمية بعيدة عن التظاهر الذي يعطل مصالح المواطنين في & 11 \\
\hline 0.51 & يَنقِل الأخبار الهامة عن الوطن بين أقرَانه كما هي دون تحريف فيها لتصل الحقيقة للجميع. & 19 \\
\hline 0.40 & يَختار بشكل حر ما يمثله من المرشحين عن طريق عملية الإتخابات لخدمة الوطن. & $r \cdot$ \\
\hline $\mathbf{0 . 3 5}$ & يُشُجع بإيجابية ترشيح المرأة لإظهار إمكاناتها في خدمةٌ وطنها من خلال مجلس الثعب. & YI \\
\hline$\% 15.11$ & نسبة التباين & \\
\hline 7.6 & الجذر الكامن & \\
\hline
\end{tabular}




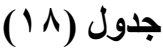

التثبعات الخاصة بالعامل الرابع (البعد العكري)

\begin{tabular}{|c|c|c|}
\hline التشبعات & العبارة & 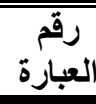 \\
\hline 0.61 & يَجمَع مع أقر انه أحلث الأسلحة لتكوين جيش قُوي لمحاربة أعداء الوطن وحمايته. & r \\
\hline 0.51 & الأعدَاءع. بـقة البطاقات المطلوبة لعبور الأشخاص إلى داخل الوطن لتأمينه من دخول & r \\
\hline 0.49 & يُحيب رجال الثرطة في الثشارع للقيام بدورهم في حماية ومساعدة المواطنين وممتلكاتهم. & $r \varepsilon$ \\
\hline 0.40 & يَرَفداء. بثدة تثويه الرموز العسكرية للوطن وإظهار بطولاتهم لعدم إستغلال ذلك من & ro \\
\hline 0.35 & يُهاجم بقوة كجندي أي مجموعات مسلحة تهذف لهلام الدولة بمساعدة الثعب. & rq \\
\hline 0.33 & يَشْكُر جهود رجال الجيش في إنقاذ المواطنين وقت الأزمات التي تمر بالوطن. & TV \\
\hline $\mathbf{0 . 3 0}$ & يُسبرع للإنضمام إلى أقرانه الجنود لتأدية الخدمة الوطنية في حماية الوطن مهما طُلب منه. & rA \\
\hline$\% 9.13$ & ن ن التبة التبن & \\
\hline 4.2 & الجذر الكامن & \\
\hline
\end{tabular}

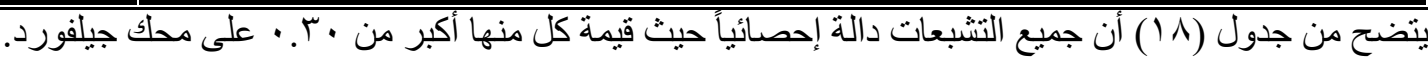

جلول (19)

التشبعات الخاصة بالعامل الخامس (البعد البيئي)

\begin{tabular}{|c|c|c|}
\hline التشبعات & العبارة & 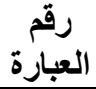 \\
\hline 0.51 & 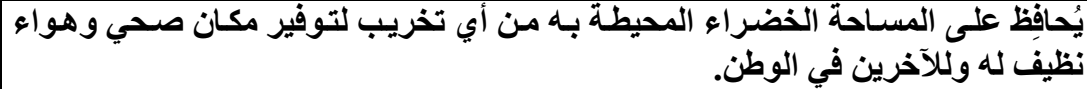 & rq \\
\hline 0.44 & يُوذِع مياه نهر النيل بالتساوي بين المواطنين للحفاظ على حياتهم بداخل بلادهم. & $r$. \\
\hline 0.40 & والإنتادماء بلألهبة بحصول كل المواطنين على نفس الكمية من خيرات البلا ليشعرون بالعدل & $r$ \\
\hline 0.38 & 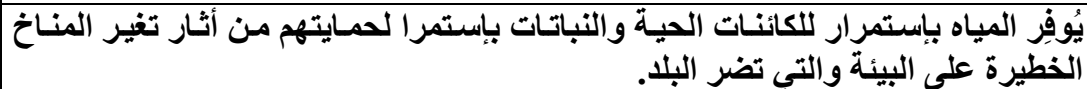 & rr \\
\hline 0.33 & 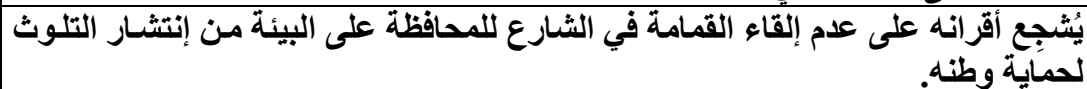 & $r \mu$ \\
\hline 0.31 & يُصسِم مع أقر انه لوحة شمسية كبديل للكهرباء لتوفير الطاقة للحفاظ على موارد الوطن. & $r \varepsilon$ \\
\hline $\mathbf{0 . 3 0}$ & يُوازِن في تقسيم كمية المياه المتاحة لايه وفقاً للإحتياج لها لعدم إهدارها. & ro \\
\hline$\% 7.11$ & نسبة التباين & \\
\hline 2.94 & الجذر الكامن & \\
\hline
\end{tabular}

يتضح من جدول (9 1 ) أن جميع التشبعات دالة إحصائياً حيث قيمة كل منها أكبر من · ؟ . • على محك جيلفورد. معاملات الثبات

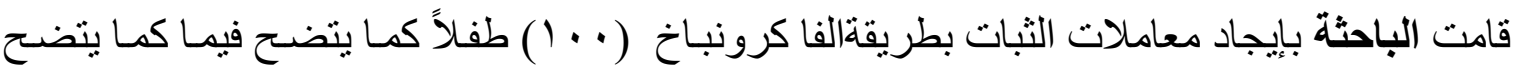

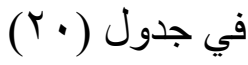

ا ـ بطريقة الفا كرونباخ

قامت الباحثّة بإيجـاد معـاملات الثبـات لبطاقة ملاحظـة آدائبـة لممارسـات أطفـال الروضــة المرتبطـة

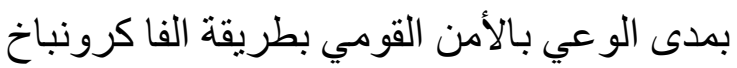




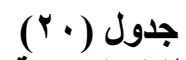

معاملات الثبات لبطاقة ملاحظة آدائية لممارسات أطفال الروضة المرتبطة بمدى الوعي بالأمن القومي بطريقة الفا كرونباخ الروض الرياخ

\begin{tabular}{|c|c|}
\hline معاملات الثبات(الفا) & الأبعاد \\
\hline$\therefore \wedge^{\prime}$ & البعد الإقتصادي \\
\hline$\cdot . \wedge \varepsilon$ & البعد الإجتماعي \\
\hline$\cdot .14$ & البعد السياسي \\
\hline$\because . \wedge r$ & البعد العسكري \\
\hline$\because \wedge \mathrm{V}$ & البعد البيئي \\
\hline$\cdot \wedge \varepsilon$ & الارجة الكلية \\
\hline
\end{tabular}

يتضح من جدول ( • r) أن قيم معاملات الثبات مرتفعة مما يدل على ثبات المقياس.

ـ - برنامج أنشطة دراما إبداعية لتنمية الوعى بالأمن القومى لأطفال الروضة. [إعداد/ الباحثة]

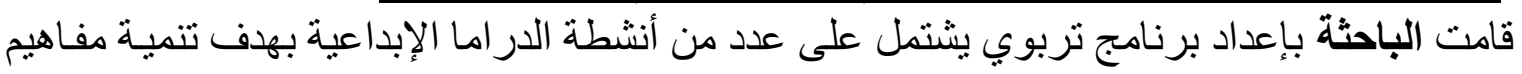

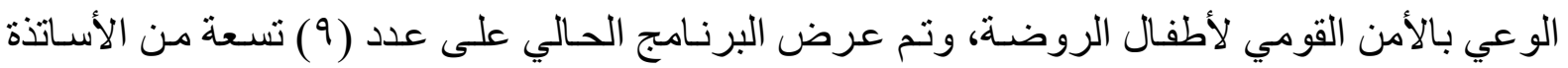

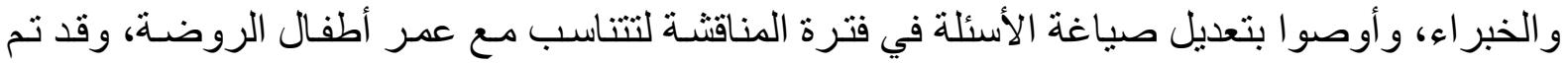
حساب صدق المحكمين على أبعاد البرنامج كما هو موضوح الاسلة في فئرة الجدول التالي: جدول (Y) (Y)

النسبة المئوية لاتفاق آراء المحمين علي برنامج أنثطة الدراما الإبداعية لتنمية الوعي بالأمن القومي لأطفال الروضة

\begin{tabular}{|c|c|c|}
\hline نسبة الإتفات & عدد المتفقين & بنود التحكيم \\
\hline$\% 1 \ldots$ & 9 & التصميم العام للبِرنامج \\
\hline$\% 1 \ldots$ & 9 & الأهداف الإجرائية \\
\hline$\% \wedge$ & $\mathrm{V}$ & أنشطة الأمن القومي الإقتصادي \\
\hline$\% 1 \ldots$ & 9 & أنشطة الأمن القومي الإجتماعي \\
\hline$\% 9$ & $\Lambda$ & أنشطة الأمن القومي السياسي \\
\hline$\% 1 \ldots$ & 9 & أنشطة الأمن القومي العسكري \\
\hline$\% 1 \ldots$ & 9 & أنشطة الأمن القومي البيئي \\
\hline$\% 9$. & $\Lambda$ & محتوي أنشطة الدرامـا الإبداعية \\
\hline $\mathbf{0} \% \wedge$. & $\mathrm{V}$ & أسئلة فترة المناقشة \\
\hline
\end{tabular}

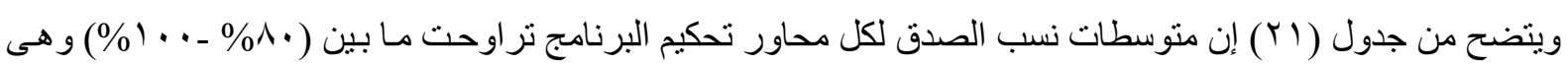
نسب صدق مرتفعة. الهدف العام للبرنامج: يهذف برنامج الأنشطة إلى تنمية بعض أبعاد الوعي بـالأمن القومي و المفـاهيم المرتبطة بهـا لأطفال

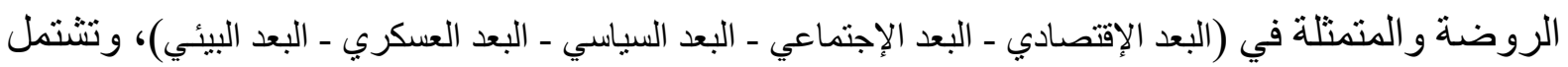

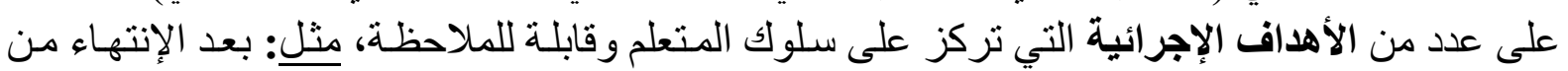

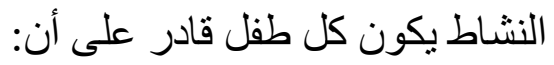

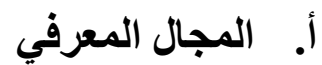
- بستنتج أهمية توفير الغذاء بسعر مناسب لكل مو اطن في بلده. [مستوى: الفهر]

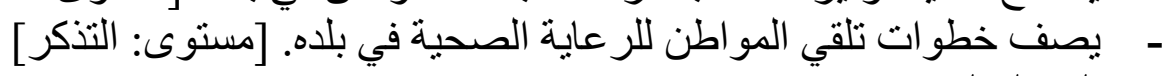

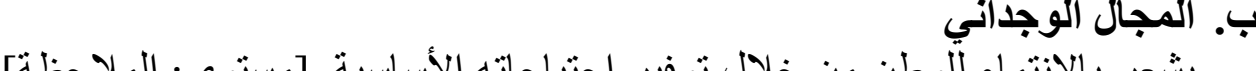

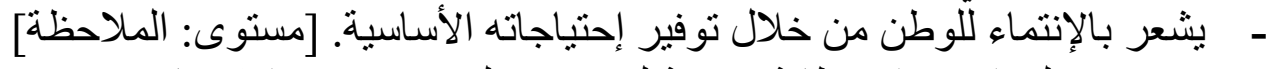

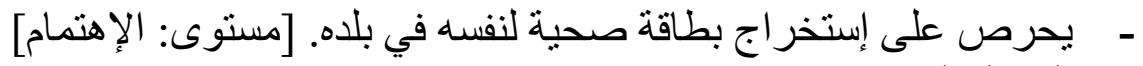
ت. ت المجال المهاري - ينفذ بعض أدوار الشخصيات بشكل إرتجالي [مستوى: التجريب] 
يؤدي بعض الحركات المرتجلة المعبرة عن عملية الإنتخابات و الفرز. [مستوى: الممارسة]

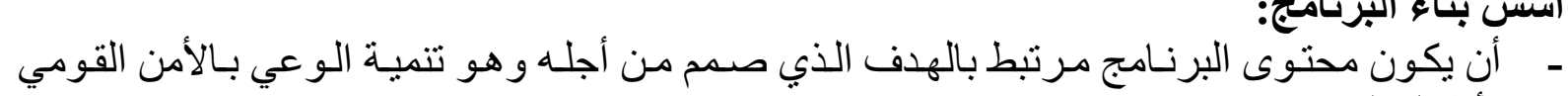

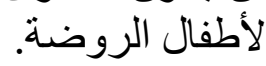

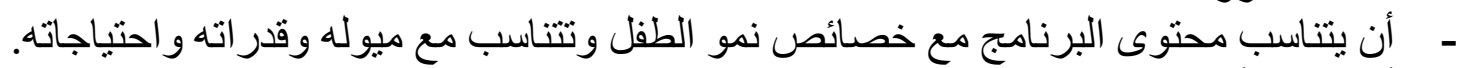

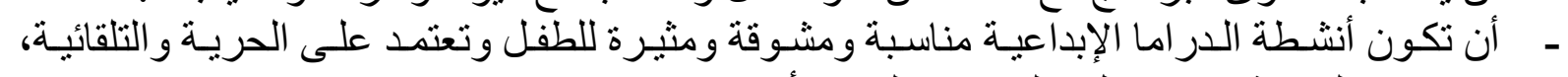

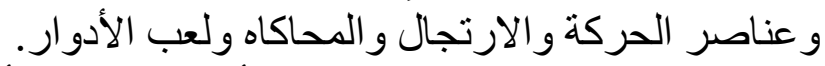

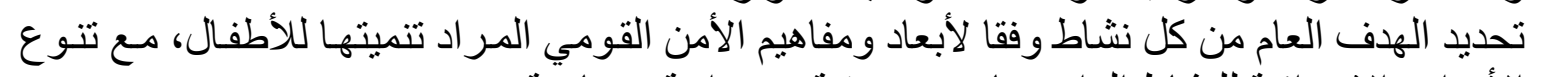

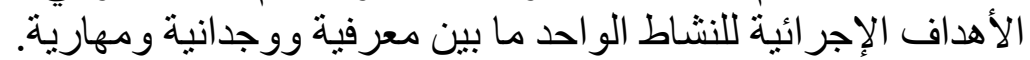

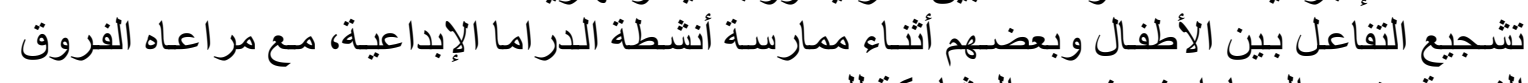

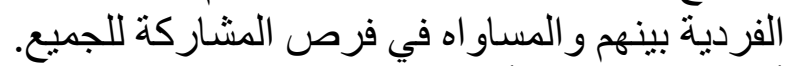

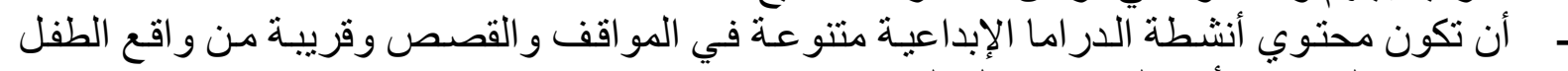

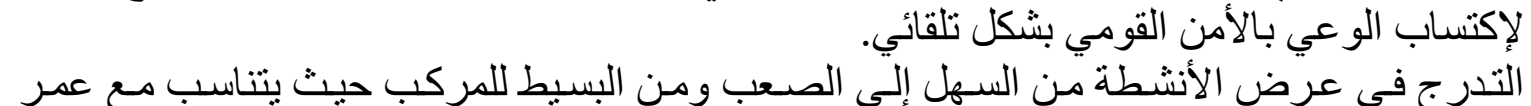

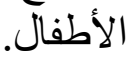

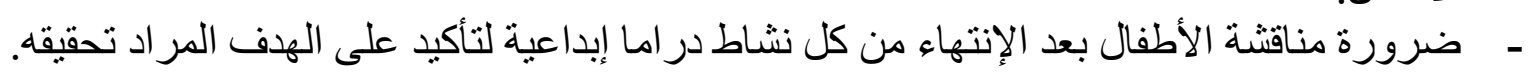

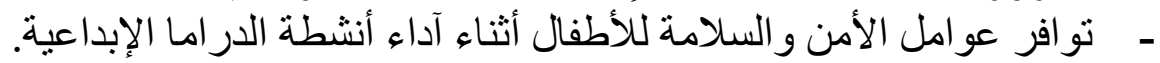

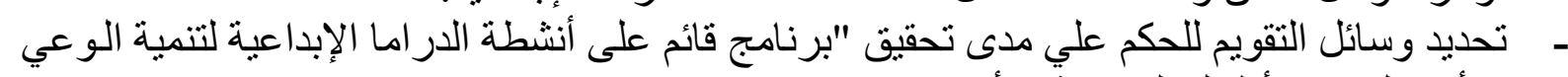

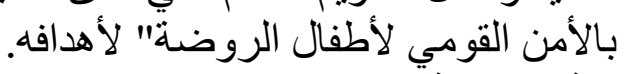

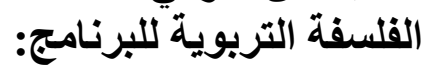

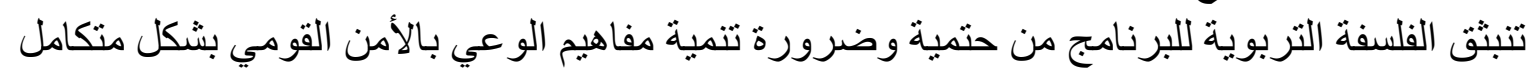

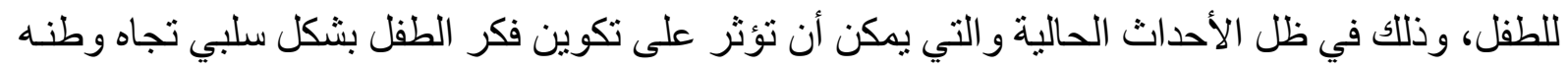

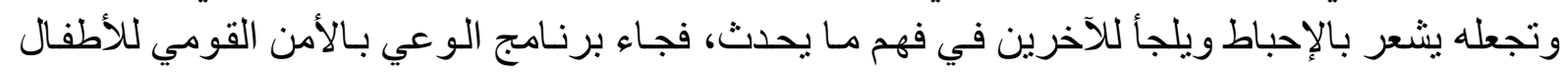

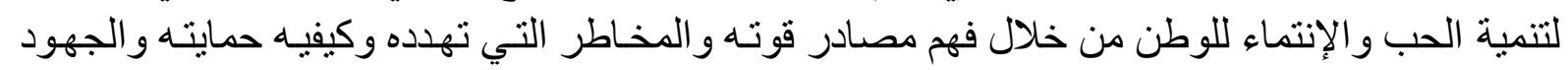

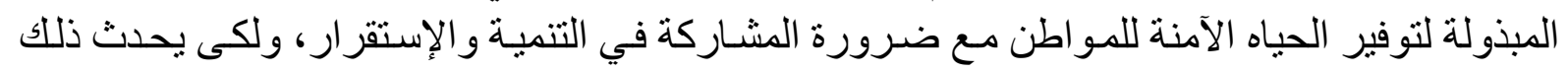

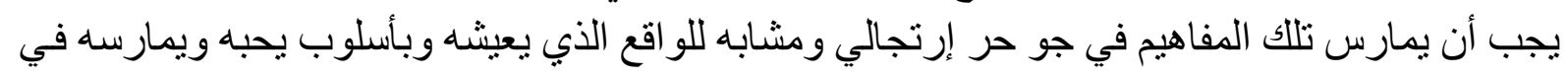

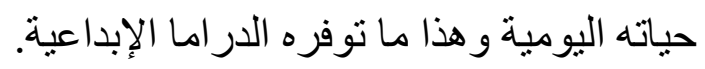
محتوى برنامج الاراما الإبداعية:

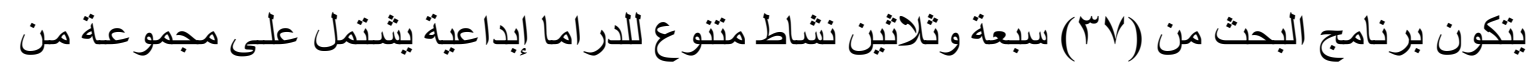

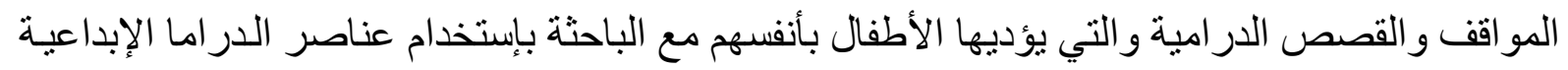

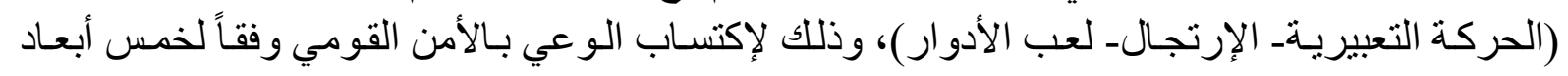

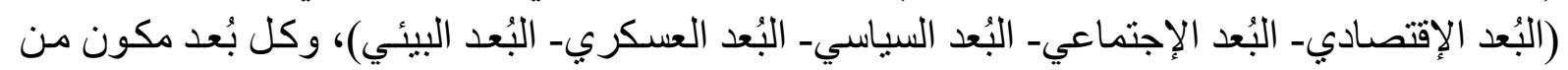

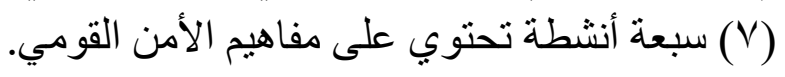

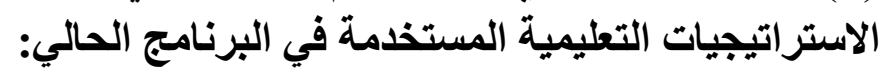

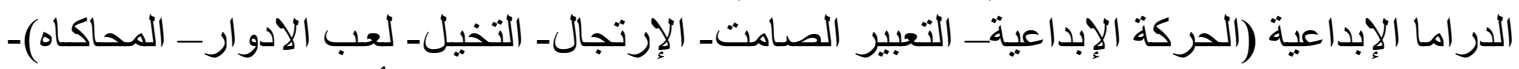

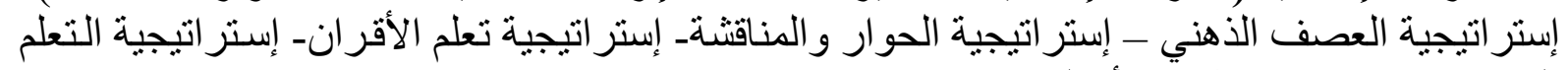

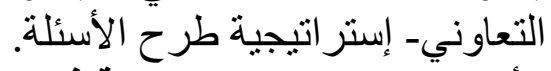

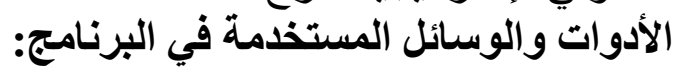

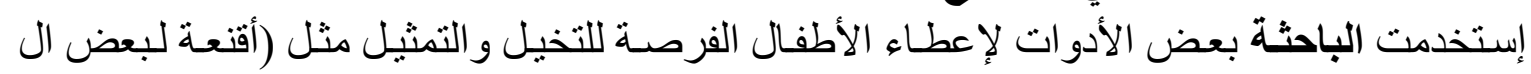

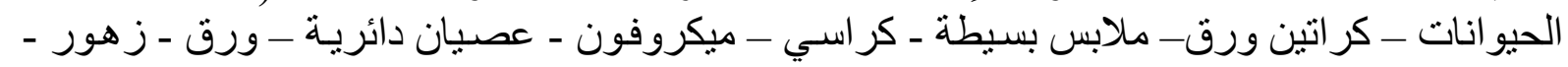


شعر أبيض - نظارة نظر - منضدة - بعض الإكسسو ار ات للشخصياتـ بعض الفو اكهه ـ شمسية ـ علم

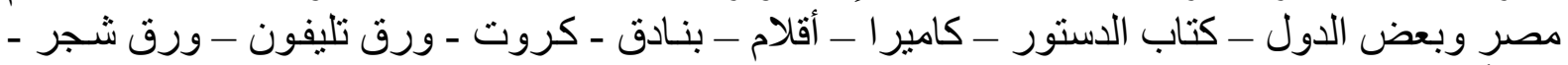

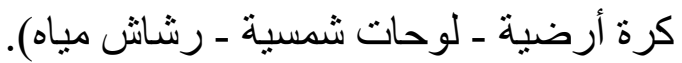

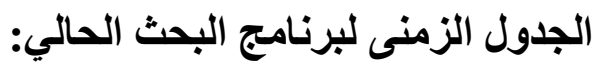

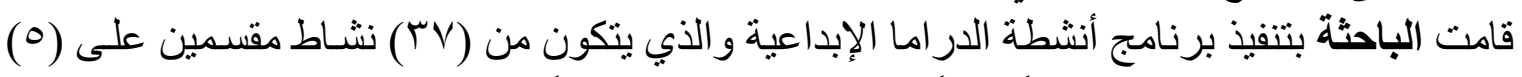

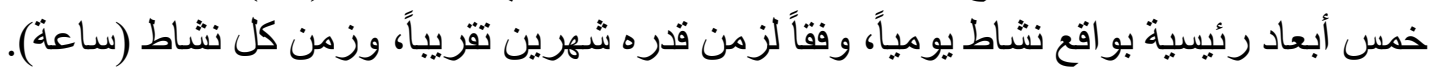

\section{وسائل تقويم البرنامسج:}

قامت الباحثة بإستخدام أساليب التقويم التالية:

تقويم قبلي: وذلك من خلال تطبيق مقياس البحث على الأطفال قبل تطبيق البرنامج لمعرفـة مستو اهم

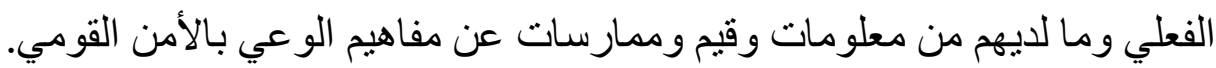

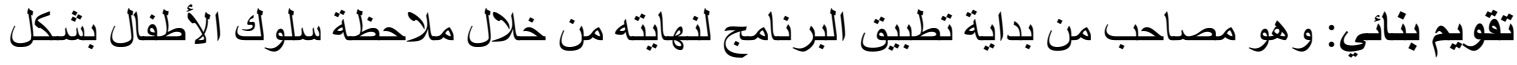

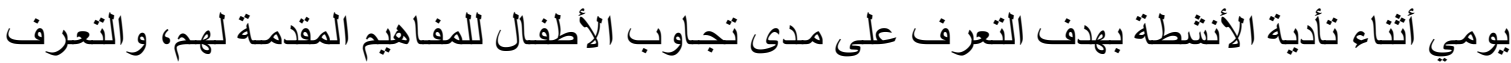

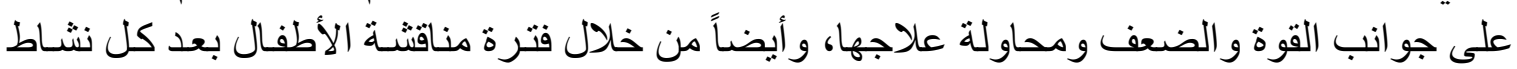
در اما إبداعية وذللك بصورة جماعية. تقويم بعدي : وذلك من خلال إعادة تطبيق مقياس البحث على الأطفال بلى بعد تطبيق البرنـامج لمعرفة

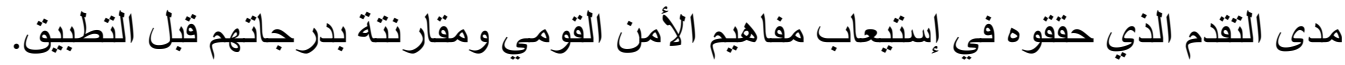

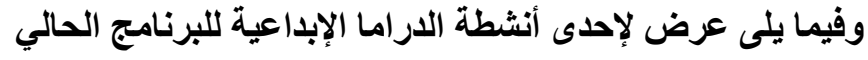

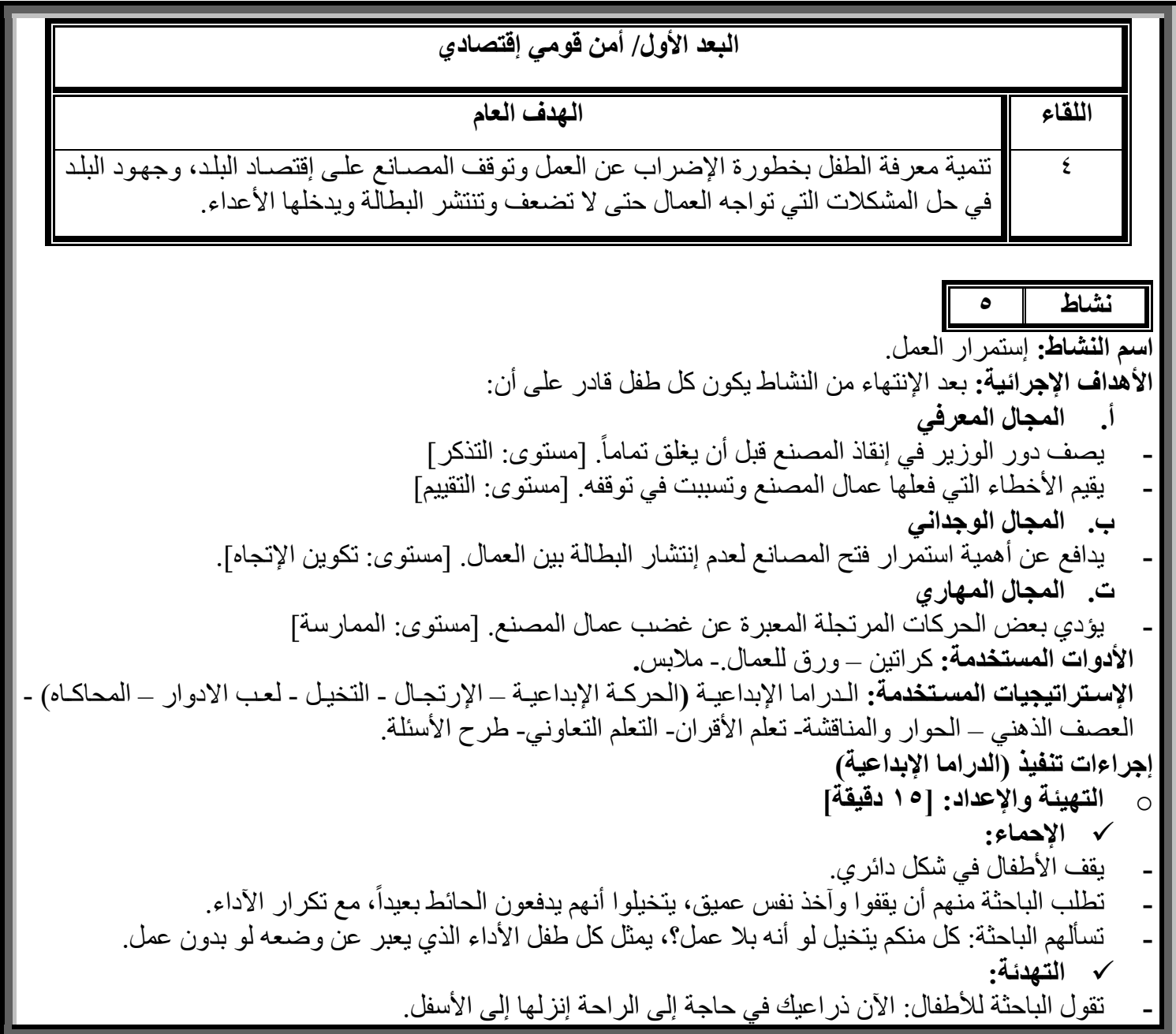




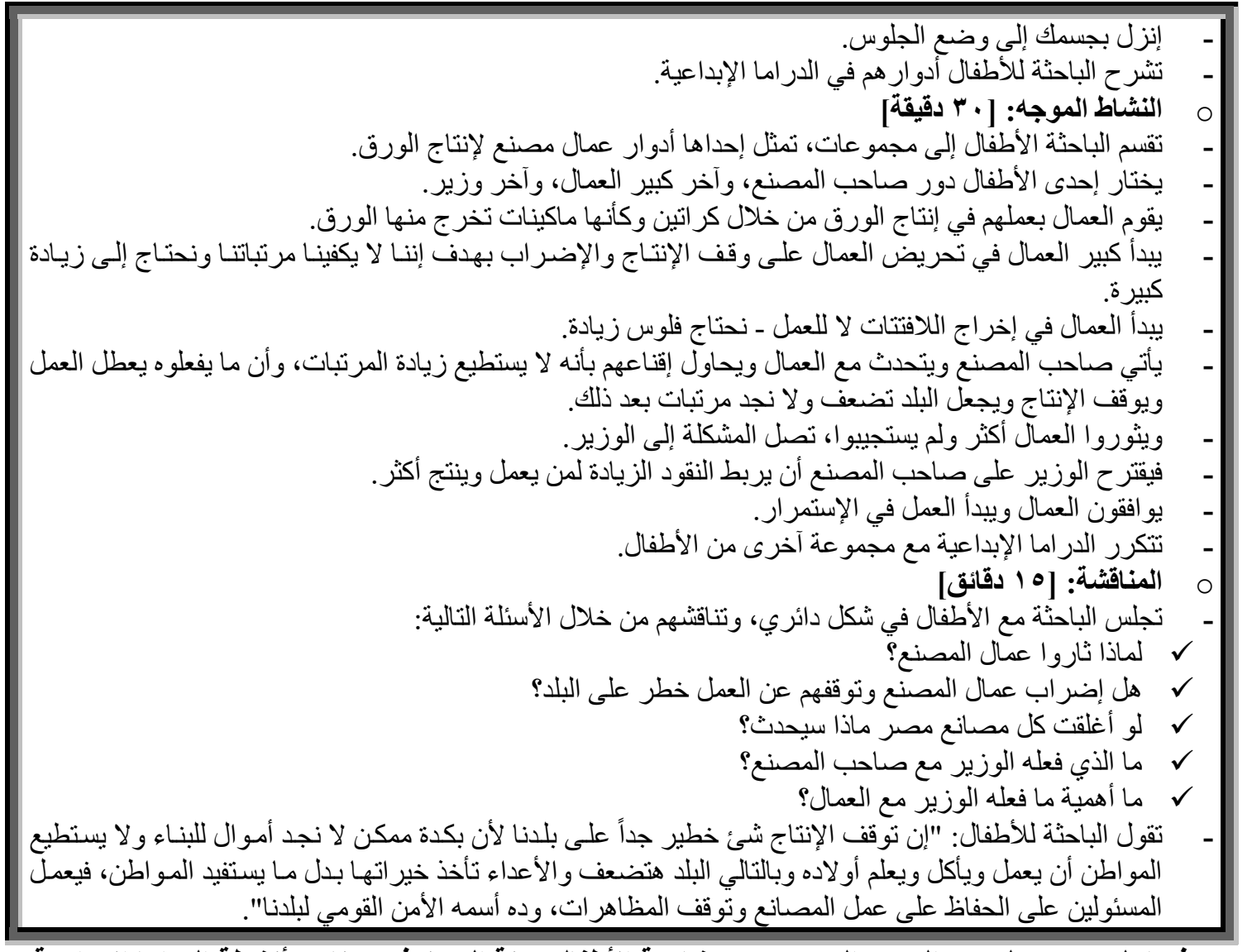

وفيما يلى عرض لبعض الصور التي توضح مشاركة الأطفال عينة البحث في برنامج أنشطة الار امـا الإبداعية

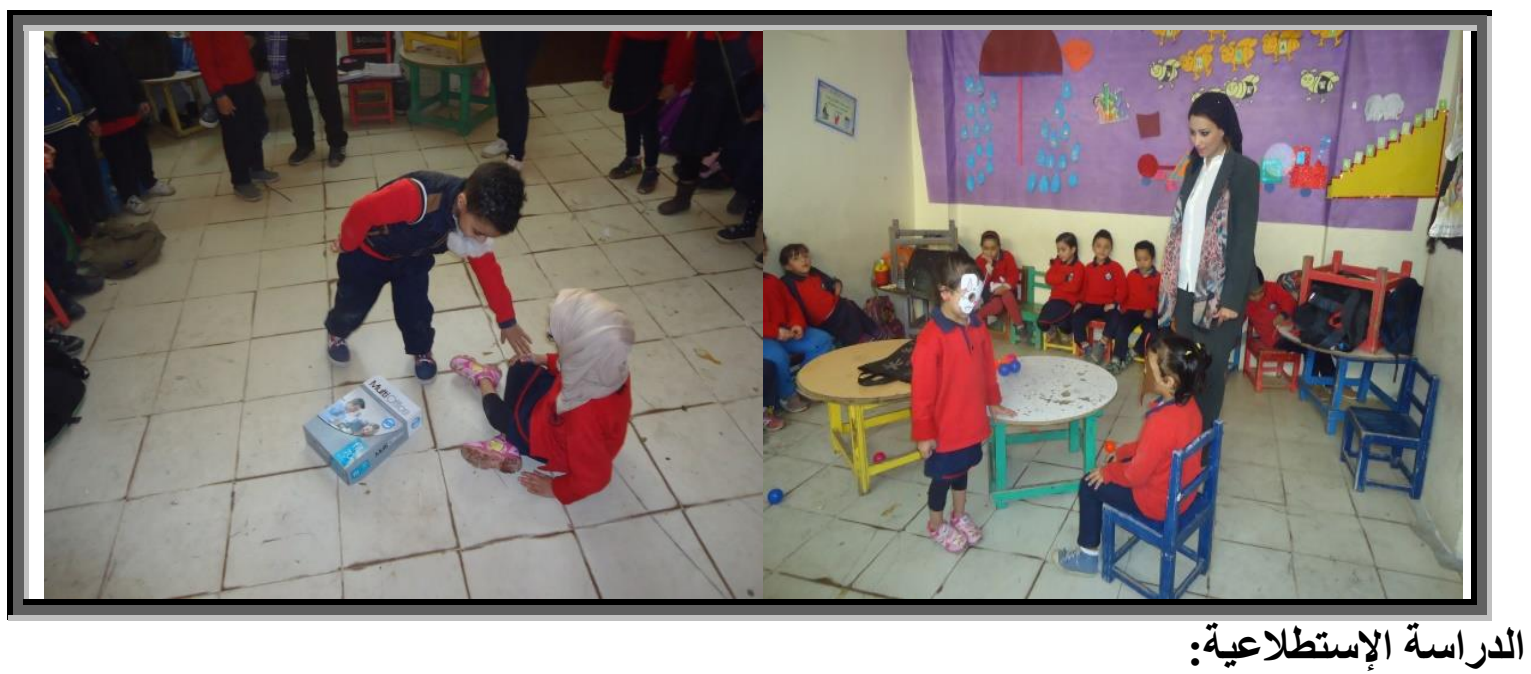

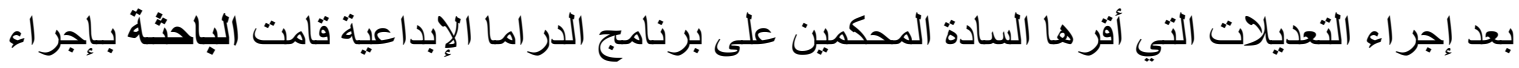
در اسة إستطلاعية لأنشطة البرنامج المستخدمة في البحث على عينة عددها ( • ( ) طفلاً وطفلة من أطفال

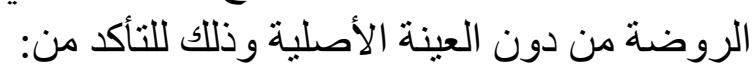

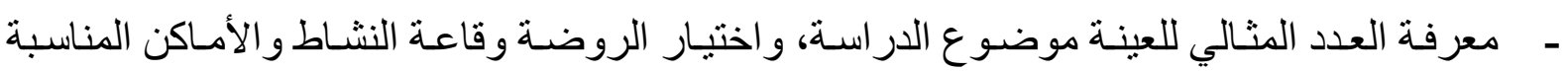

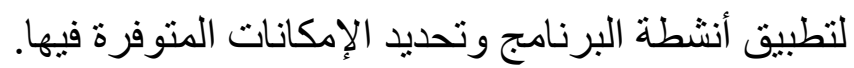

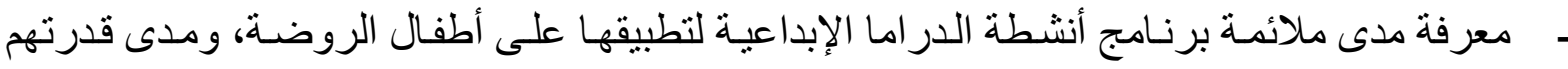
على ممارسة عناصر الدر اما الإبداعية. - التعرف على مدى ملائمة الزمن المحدد لتنفيذ كل نشاط. 
- - مدريد أساليب التعزيز الملائمة للأطفال.

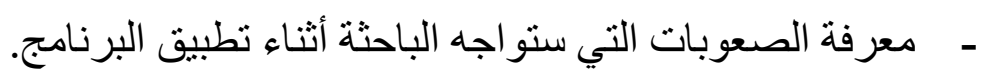

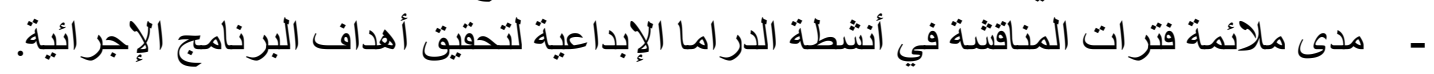

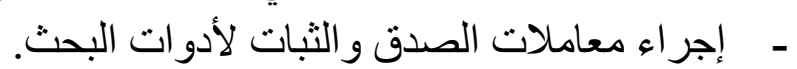
- - تدريب المعلمات المساعدات على ملاحظة الأطفال أنثاء تنفيذ الأنشطة. وجاءت نتائج الدراسة الاستطلاعية كالتالي:

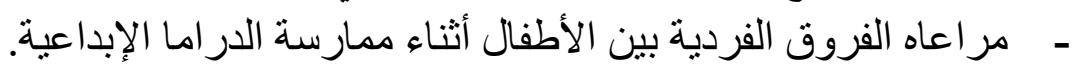

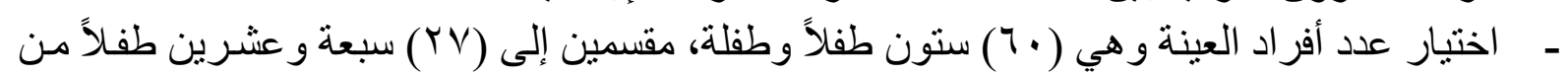

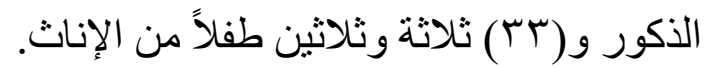

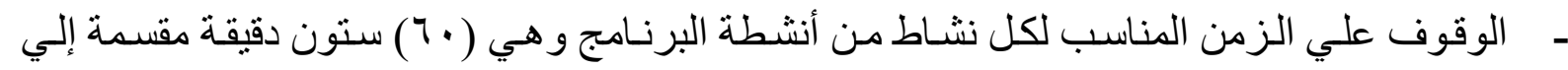

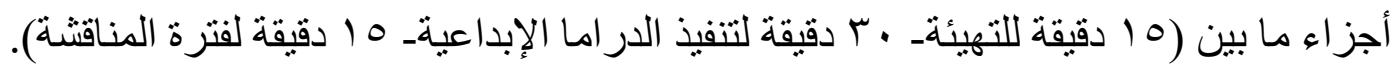

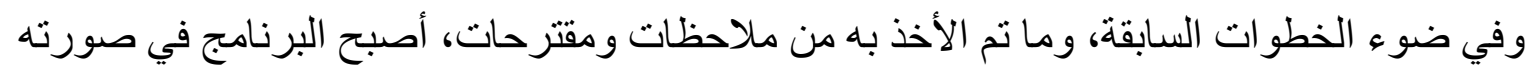

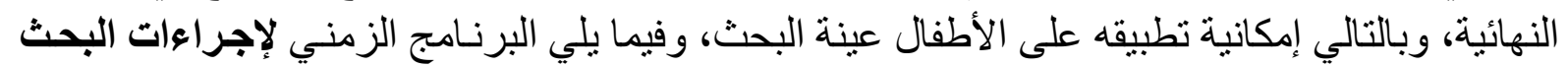
على أطفال الروضة، كما هو موضح في جدول (Yr) جدول (r)

البرنامج الزمني لإجراءات البحث على أطفال الروضة

\begin{tabular}{|c|c|c|c|c|c|}
\hline \multicolumn{2}{|c|}{ عدد الأيـام التطبيق } & \multirow[t]{2}{*}{ المكان } & \multirow[t]{2}{*}{ عدد العينة } & \multirow[t]{2}{*}{ الههدف } & \multirow[t]{2}{*}{ الإجراءات } \\
\hline إلى & من & & & & \\
\hline \multicolumn{2}{|c|}{ ع أيام } & \multirow{2}{*}{ خاصة فية } & \multirow{2}{*}{ 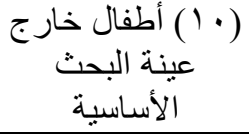 } & \multirow{2}{*}{ المقياس وفة مدى ملانئمة } & \multirow{2}{*}{ الاستطلاعية } \\
\hline$r .19 / 1 r / 11$ & $r .19 / 1 r / 10$ & & & & \\
\hline \multicolumn{2}{|c|}{ يو مان } & \multirow{2}{*}{ النشاطة } & \multirow{2}{*}{ 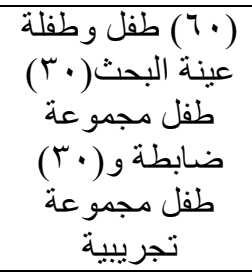 } & \multirow{2}{*}{ وحلى عينة البحاث القيات الأساسية القبلية } & \multirow{2}{*}{ القباسى } \\
\hline$r \cdot r \cdot / / / r$ & $r \cdot r \cdot / l / 1$ & & & & \\
\hline \multicolumn{2}{|c|}{ حو الي شهرين } & \multirow{2}{*}{ وخار جاخل } & \multirow{2}{*}{ التينة البحثة } & \multirow{2}{*}{ تنفيذ المجمو عة التجريبية } & \multirow{2}{*}{ تطبيتى البرنج } \\
\hline$r \cdot r \cdot / r / q$ & $r \cdot r \cdot / 1 / 11$ & & & & \\
\hline \multicolumn{2}{|c|}{ يومان } & \multirow{2}{*}{ النشاطة } & \multirow{2}{*}{ 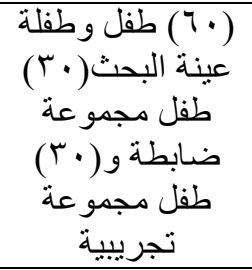 } & \multirow{2}{*}{ قياس متغير ات البحث بعدة البرنامج } & \multirow{2}{*}{ البعدى الباس } \\
\hline$r \cdot r \cdot / r / l 1$ & $r \cdot r \cdot / r / l \cdot$ & & & & \\
\hline \multicolumn{2}{|c|}{ أسبوع } & \multirow[t]{2}{*}{ المنزي } & \multirow{2}{*}{ 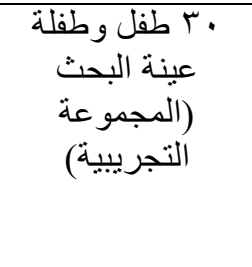 } & \multirow{2}{*}{ 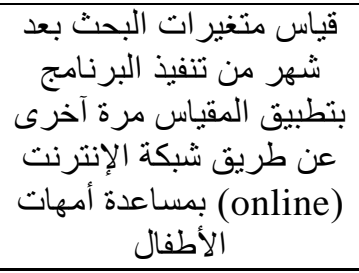 } & \multirow[t]{2}{*}{ التبعيس } \\
\hline$r \cdot r \cdot / \varepsilon / / \Lambda$ & $r \cdot r \cdot / \varepsilon / T r$ & & & & \\
\hline
\end{tabular}




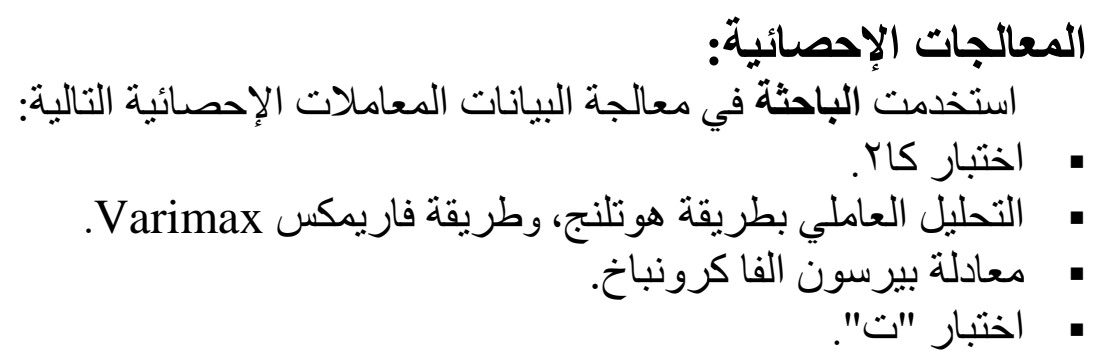

\section{عرض النتائج وتفسير ها: نتائج الفرض الاول}

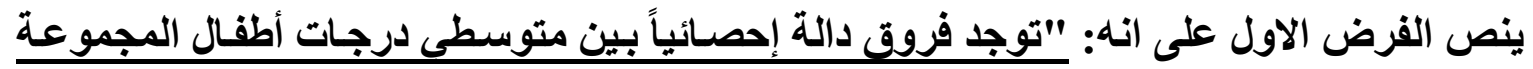

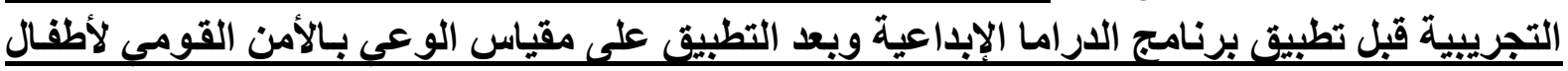

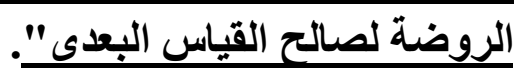

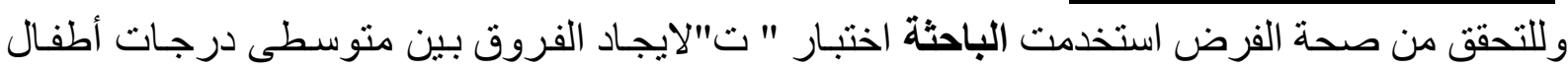

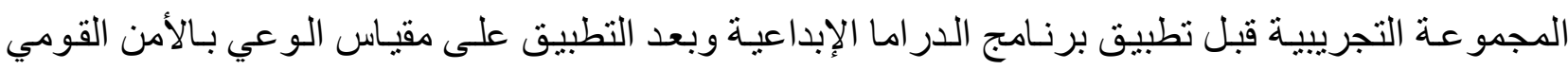

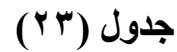

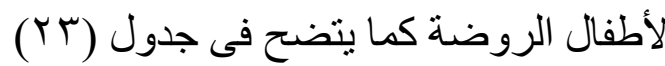

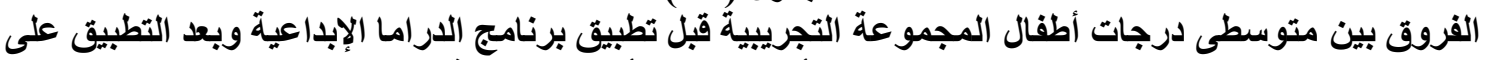
مقياس الوعي بالأمن القومي لأطفال الروضة

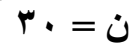

\begin{tabular}{|c|c|c|c|c|c|}
\hline \multirow[t]{2}{*}{ اتجاه الدلالة } & \multirow[t]{2}{*}{ الدالية } & \multirow[t]{2}{*}{ ت } & \multicolumn{2}{|c|}{ القياسين القبلى و البعدى } & \multirow[t]{2}{*}{ المتغيرات } \\
\hline & & & مج ح ف & م ف & \\
\hline فى التجداه القياس & دالة عند مستوى & $Y \wedge . \wedge \varepsilon$ & Y.P & $1 \cdot . \wedge 7$ & البعد الإقتصادي \\
\hline فى الجباه القياس & دالة عند مستوى & $r 0 . r$ & $1.7 \mathrm{~V}$ & $1 . .87$ & البعد الإجتماعي \\
\hline فى الجباه القياس & دالة عند مستوى & $r \cdot . \wedge$ & $1.9 \pi$ & $1 \cdot .9$ & البعد السياسي \\
\hline فى الجباه القياس & دالة عند مستوى & Yq.Y & $r$ & $1 \cdot . V$ & البعد العكري \\
\hline فى التجداه القياس & دالة عند مستوى & $\leq 1 . \pi$ & $1.0 \leq$ & 11.7 & البعد البيئي \\
\hline فى التجداه القياس & دالة عند مستوى & rr.00 & 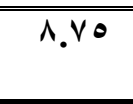 & & الارجة الكلية \\
\hline
\end{tabular}

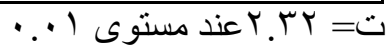

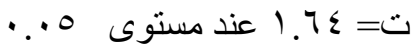

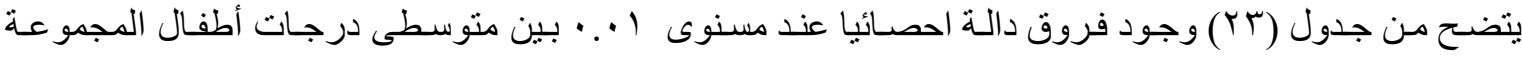

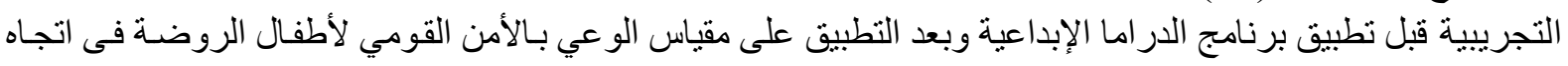

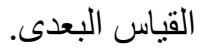

ويوضح شكل (Y) الفروق بين متوسطى درجـات أطفال المجمو عـة التجريبيـة قبل تطبيق برنـامج

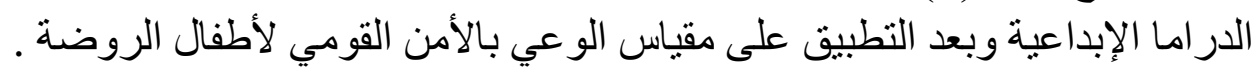




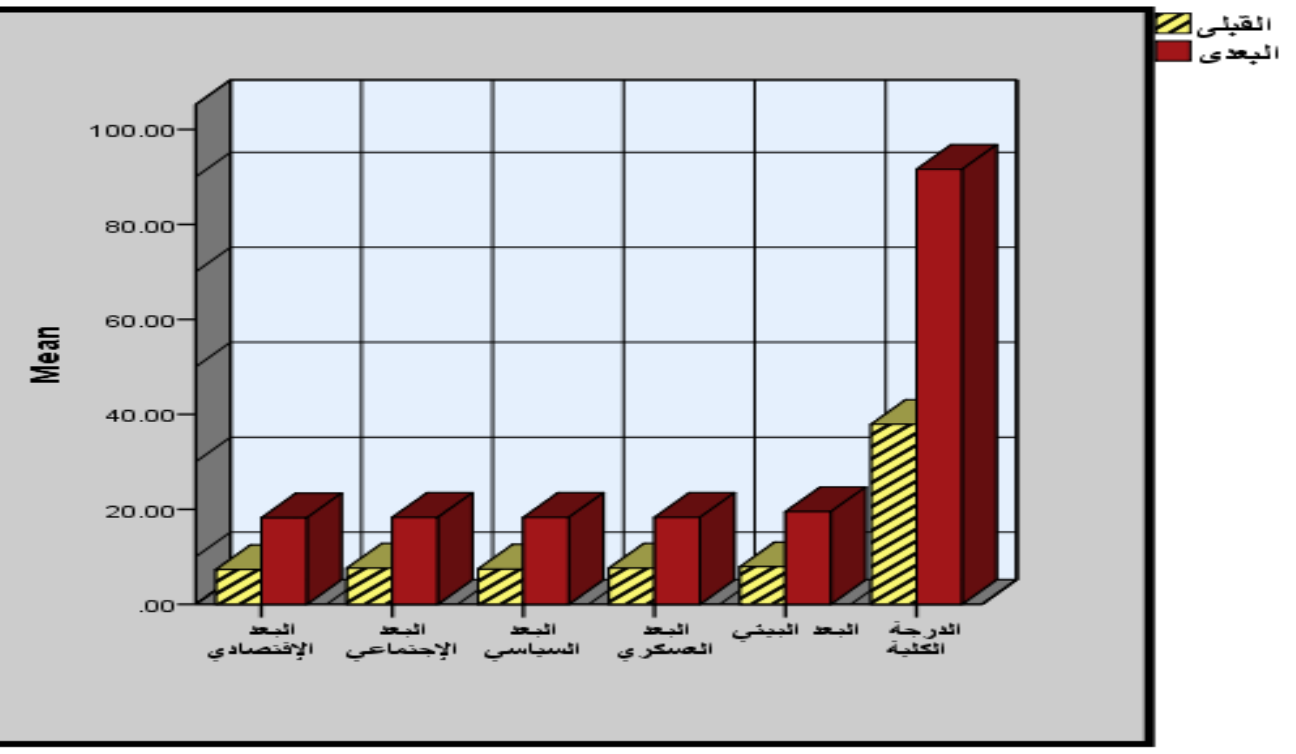

شكل (r)

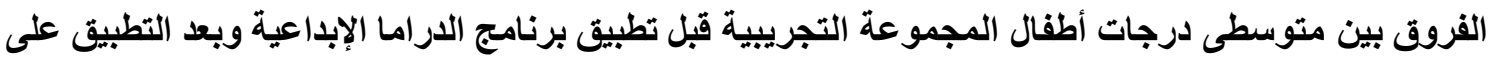
مقياس الوعي بالأمن القومي لأطفال الروضة برنة

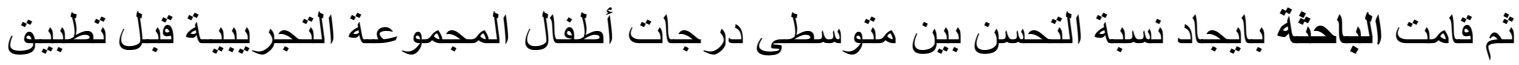

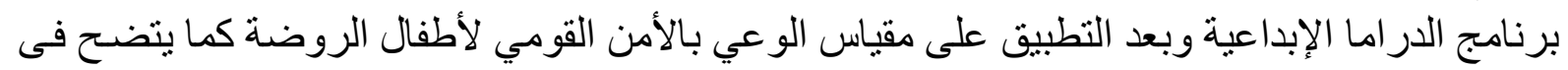

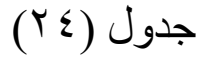

\section{جدول (}

نسبة التحسن بين متوسطى درجات أطفال المجموعة التجريبية قبل تطبيق برنامج الاراما الإبداعية وبعد التطبيق على الإيل

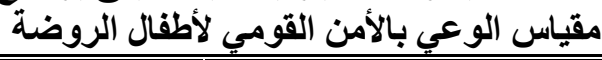

\begin{tabular}{|c|c|c|c|}
\hline نسبة التحسن & القبلى & البعدى & المتغيرات \\
\hline$\% \diamond 9 . \wedge 9$ & $V_{. T}$ & $1 \Lambda . Y$ & البعد الإقتصادي \\
\hline$\% \diamond \wedge . \leqslant 4$ & V. 7 & $1 \Lambda . r$ & البعد الإجتماعي \\
\hline$\% 09.07$ & $V_{.} \varepsilon$ & $1 \wedge . r$ & البعد السياسي \\
\hline$\% \otimes \wedge . \leqslant 4$ & $v .7$ & $1 \Lambda . r$ & البعد العسكري \\
\hline$\%$ \%9.£ᄉ & $v .9$ & 19.0 & البعد البيئي \\
\hline 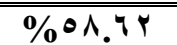 & $r v .9$ & 91.7 & الارجة الكلية \\
\hline
\end{tabular}

وتُفر الباحثة أسباب تفوق أطفال المجموعة التجريبية في القياس البعدي على مقياس الوعي بـالأمن

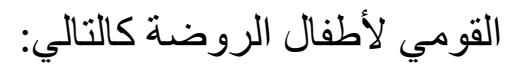

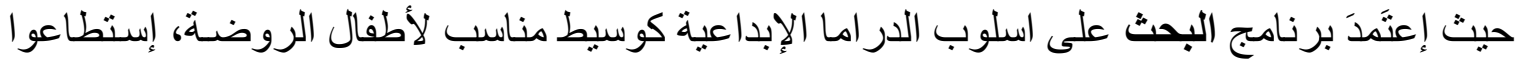

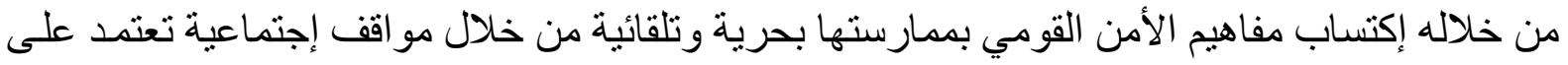
الخيال، أعطت لهم فرصة كبيرة للتفاعل ولعب الأدوار معاً والتمثيل الجماعي لها، فكان لـه الأثر في فهم

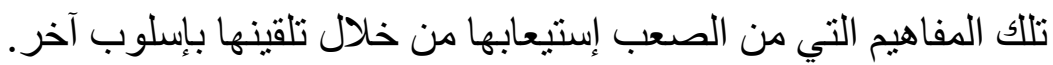

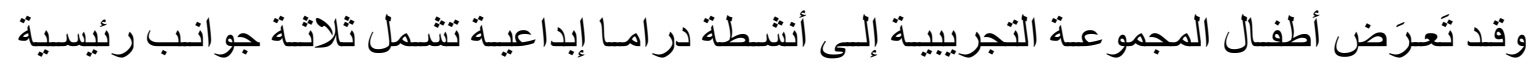

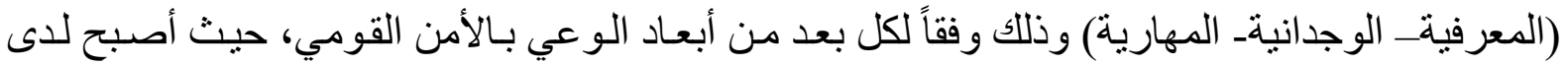

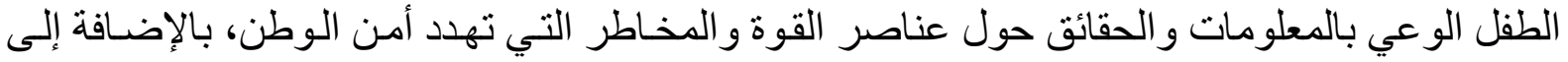

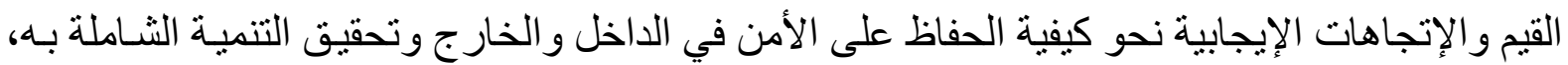

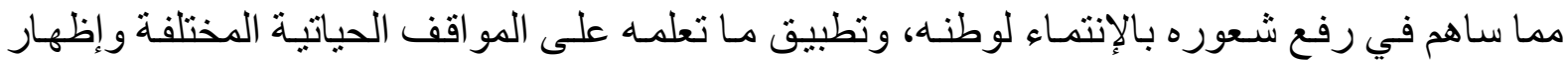




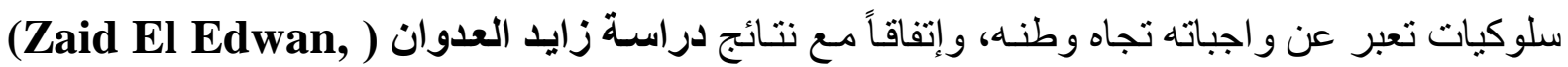

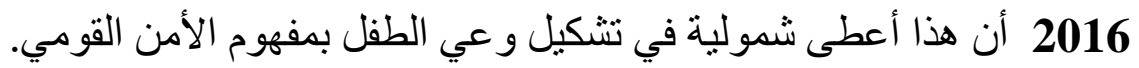

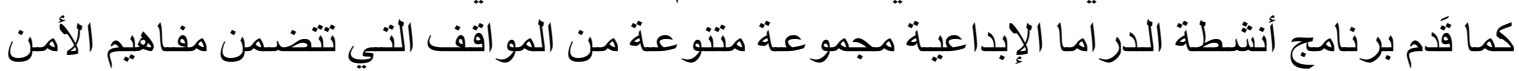

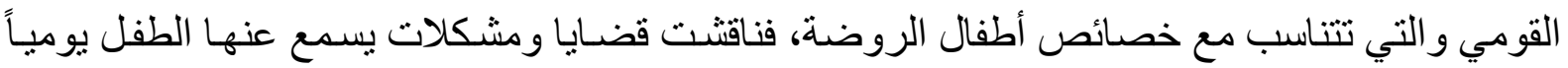

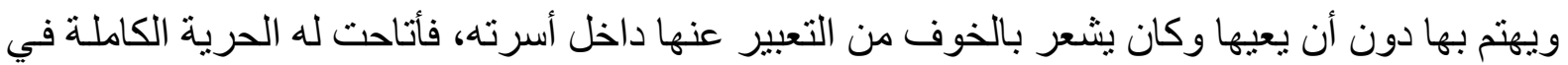

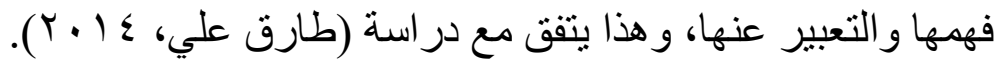

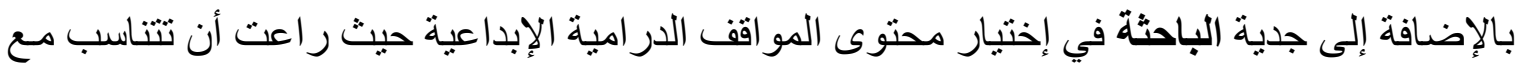

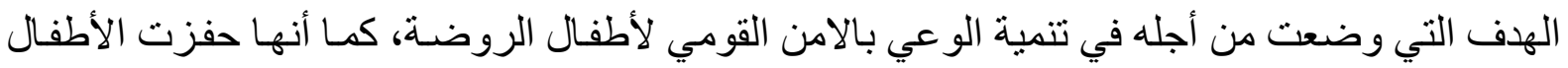

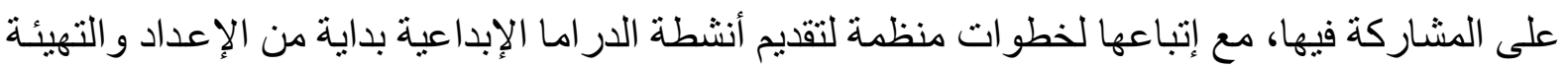

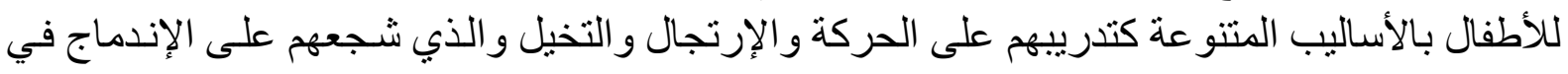

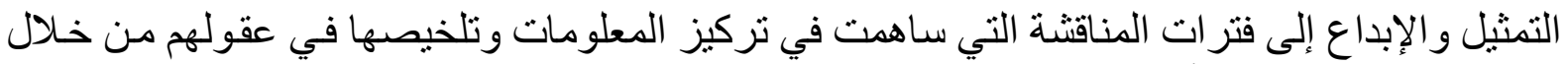

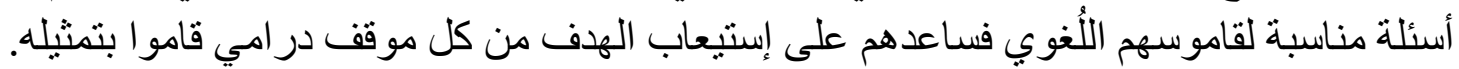

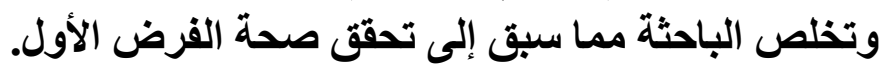
نتائج الفرض الثاني

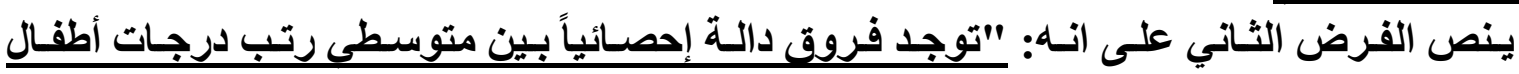

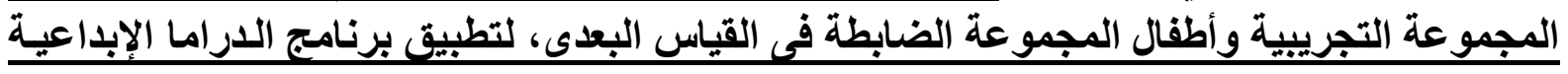

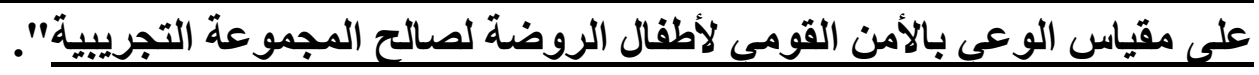

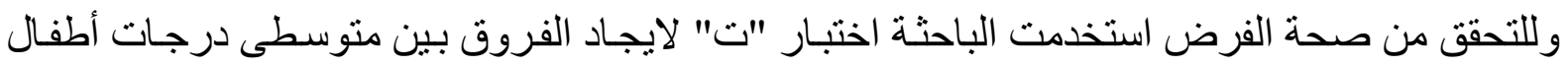

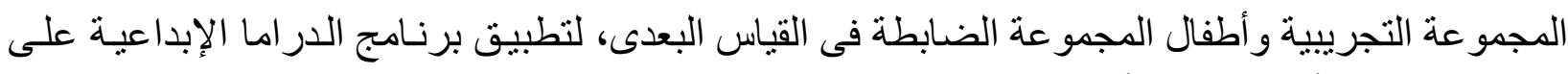

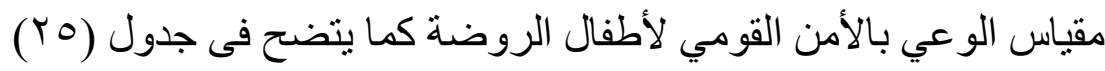

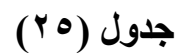

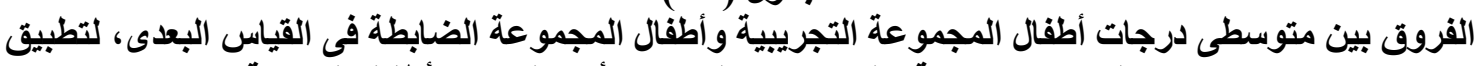

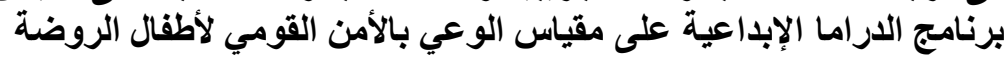

$$
\text { 1. = ن }
$$

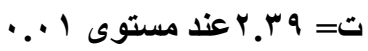

\begin{tabular}{|c|c|c|c|c|c|c|c|}
\hline \multirow[t]{2}{*}{ الدالاهة } & \multirow[t]{2}{*}{ مستوى الدلالة } & \multirow[t]{2}{*}{ ت } & \multicolumn{2}{|c|}{ الضجابطة المبة } & \multicolumn{2}{|c|}{ المحموعة التجريبية } & \multirow[t]{2}{*}{ المتغيرات } \\
\hline & & & $r \varepsilon$ & $r_{p}$ & $1 \varepsilon$ & p & \\
\hline التجريبية & دالة عند مستوى & $r \leqslant . \wedge 1$ & 99. & V.74. & Y. & $1 \wedge . r$ & البعد الإقتصادي \\
\hline التجريبية & دالة عند مستوى & YA.YT & 1.90 & $V .9 r$ & 1.01 & 11.47 & البعد الإجتماعي \\
\hline التجريبية & دالة عذد مستوى & YA.TV & 1.51 & V.7r & 1.70 & 11.49 & البعد السياسي \\
\hline التجريبية & دالة عذد مستوى & Y0.7T & $1 . Y \varepsilon$ & V.7r & 1.91 & IA.rr & البعد العسكري \\
\hline التجريبحة & دالة عند مستوى & $r \cdot . \varepsilon$ & $1 . \leqslant V$ & $\Lambda . \xi$ & 1.40 & 19.04 & البعد البيئي \\
\hline التجريبية & دالة عند مستوى 1 . . & $r 1 . \leqslant Y$ & $\Gamma . \leqslant \Lambda$ & rq.rr & $\Lambda . \leqslant \Gamma$ & 91.7 & الارجة الكلية \\
\hline
\end{tabular}




\section{ت =}

يتضح من جدول (0 ب) وجود فروق دالة احصائيا عند مستوى ( • • • بين متوسط درجات أطفال المجموعة التجريبية

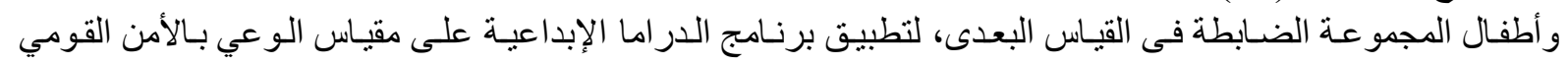
لأطفال الروضة لصالح المجمو عة التجريبية . ويوضـح شـكل (ب) الفـروق بـين منتوسـط درجـات أطفال المجمو عـة التجريبيـة و أطفـال المجمو عـة الضابطة فى القياس البعدى، لتطبيق برنامج الدراما الإبداعية على مقياس الوعي بالأمن القومي لأطفال الروضة.

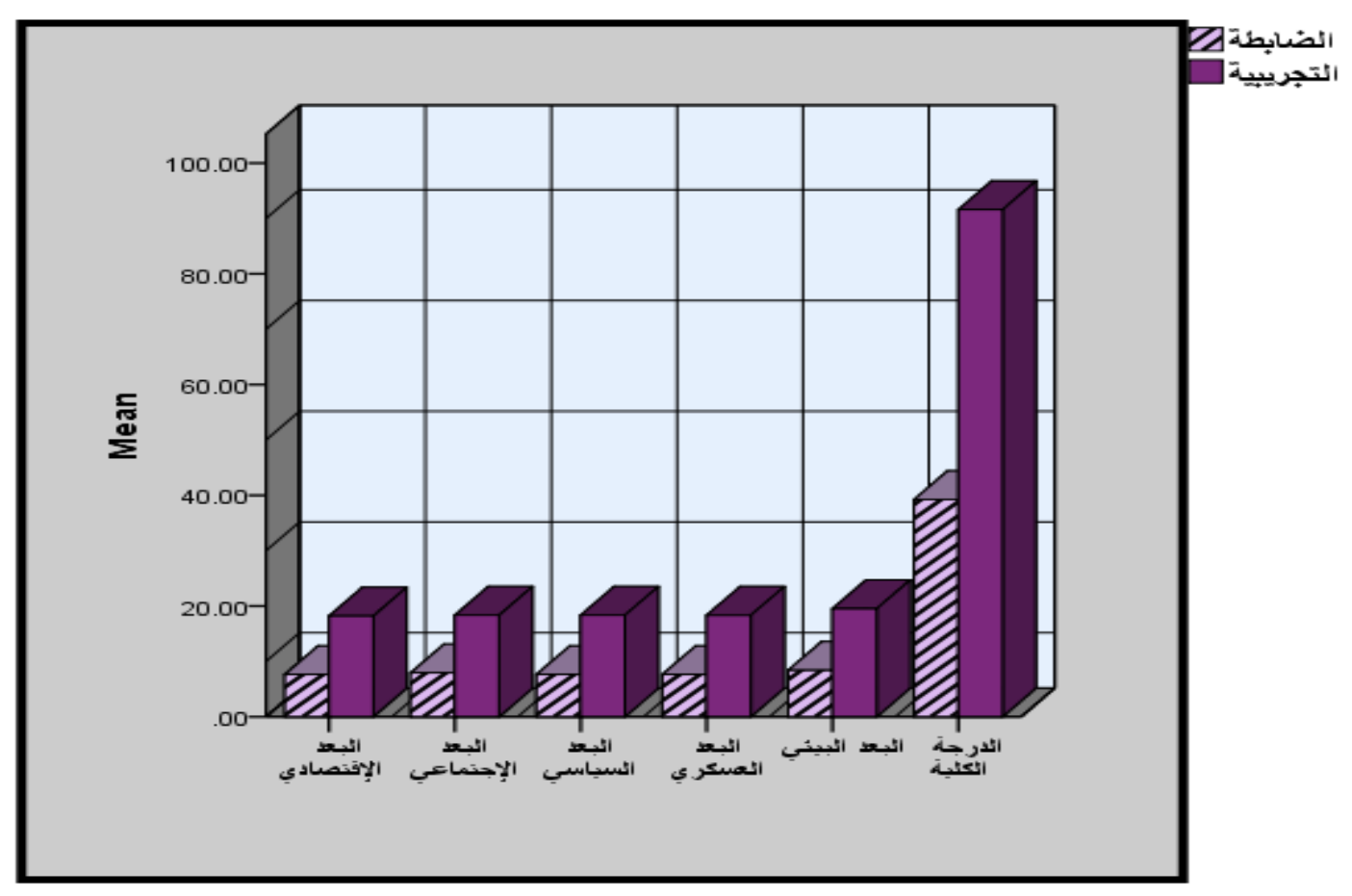

شكل (r) (ب)

الفروق بين متوسط درجات أطفال المجموعة التجريبية وأطفال المجموعة الضابطة فى القياس البعدى، لتطبيق برنامج

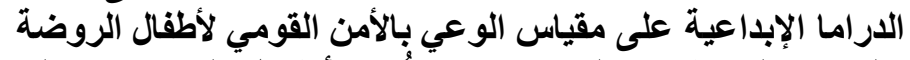

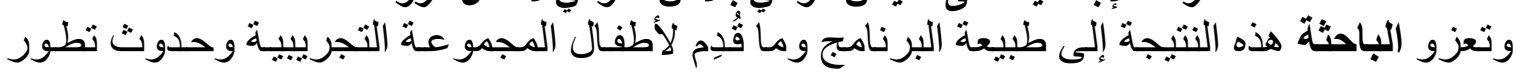

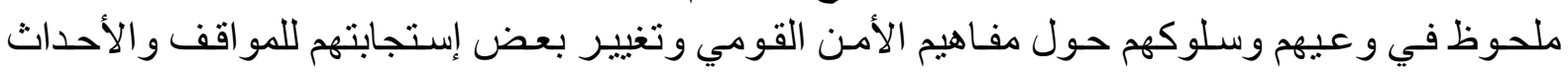

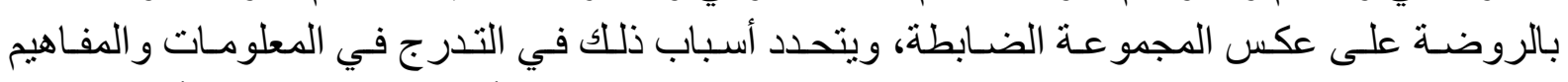

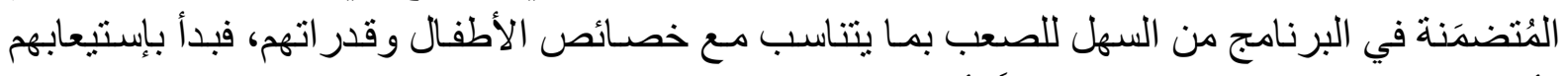

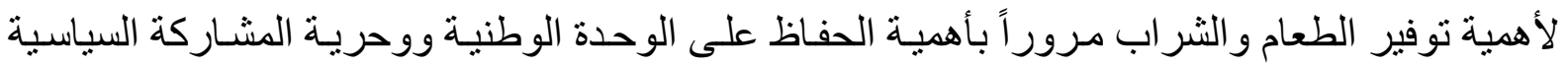

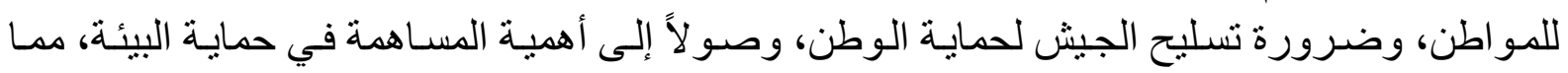

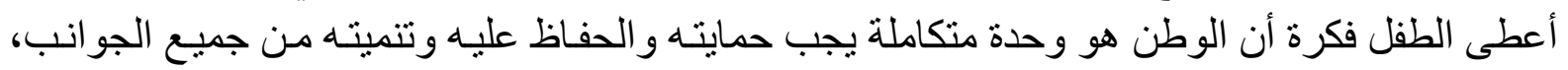

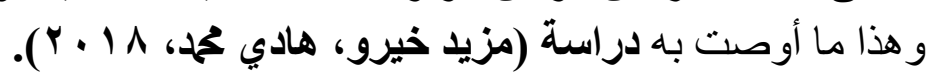

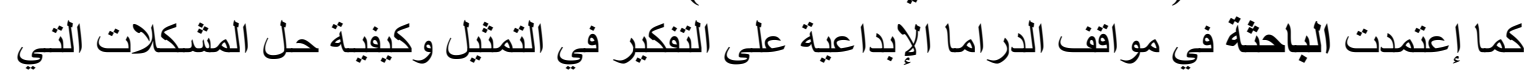

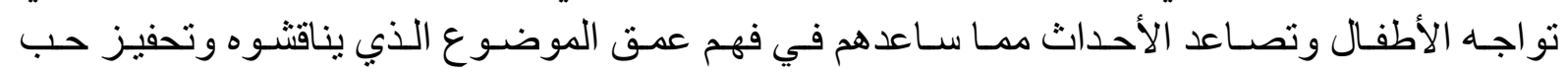

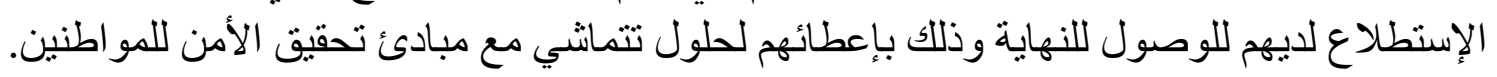

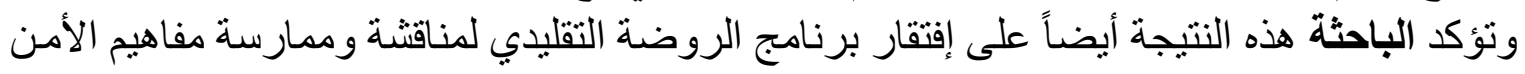

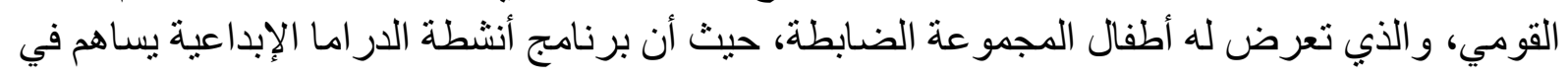


جعل بيئة الروضة تهتم بتتمية فكر الأطفال وتحصين عقو لهم من كل فكر ضـال ومعتقد خاطئ، وهذا مـا

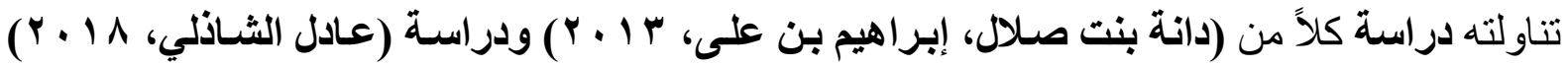

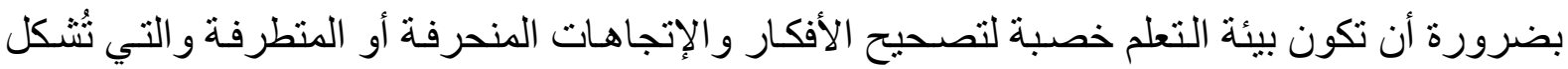
خطرًا على أمن و استقر ار المجتمع. وتخلص الباحثة مما سبق إلى تحقى صحة الفئق الفرض الثاني.

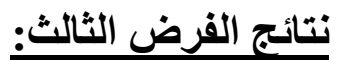
ينص الفرض الثالث على انه: "توجد فروق دالة إحصائياً بين متوسطى درجات أطفال المجموعة

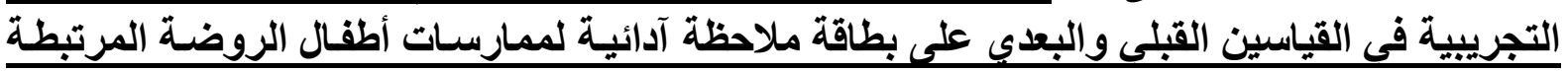

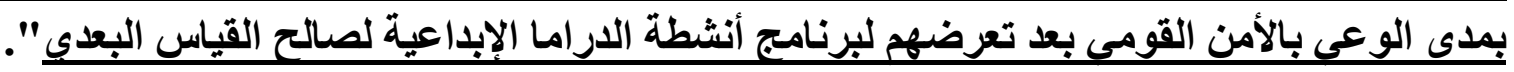

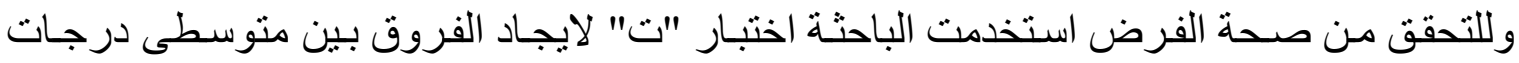
أطفال المجمو عـة التجريبيـة في القياسين القبلي و البعدي على بطاقة ملاحظة آدائية لممارسـات أطفال الروضة المرتبطة بمدى الوعي بالأمن القومي بعد تعرضهم لبرنامج أنشطة الدر اما الإبداعية كمـا يتضـح

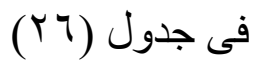

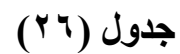

الفروق بين متوسطى درجات أطفال المجموعة التجريبية في القياسين القبلي والبعدي على البى بطاقة ملاحظة آدائية

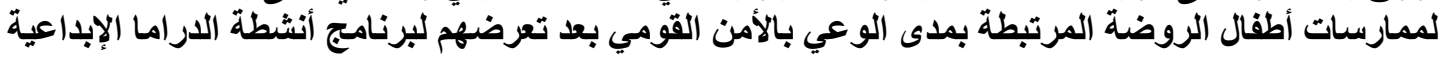

$$
\text { ن }
$$

\begin{tabular}{|c|c|c|c|c|c|}
\hline \multirow[t]{2}{*}{ اتجاه الدلالة } & \multirow[t]{2}{*}{ مستوى } & \multirow[t]{2}{*}{ 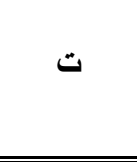 } & \multicolumn{2}{|c|}{ القياسين القبلى و البعدى } & \multirow[t]{2}{*}{ المتغيرات } \\
\hline & & & مج ح ف & م ف & \\
\hline فى اتجاه القياس & دالة عند مستوى & $1 \wedge . \wedge r q$ & 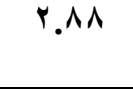 & $9.94 r$ & البعد الإقتصادي \\
\hline فى الجباه القياس & دالة عند مستوى & 19.510 & Y.AV & $1 . .1 \mathrm{rr}$ & البعد الإجتماعي \\
\hline فى التجاه القياس & دالة عند مستوى & 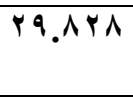 & 1.99 & $1 \cdot . \wedge 47$ & البعد السياسي \\
\hline فى التجداه القياس & دالة عند مستوى & $1 \cdot .91$ & 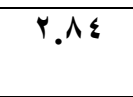 & 9.9 & البعد العسكري \\
\hline فى التجداه القياس & دالة عند مستوى & $4 . .90$ & $r .79$ & $1 \cdot . r$ & البعد البيئي \\
\hline فلى التجداه القياس & دالة عند مستوى & $r \wedge . r \vee q$ & $9 . \wedge 9$ & 01.1 & الارجة الكلية \\
\hline
\end{tabular}

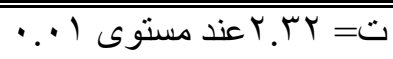

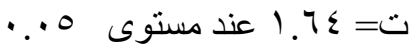

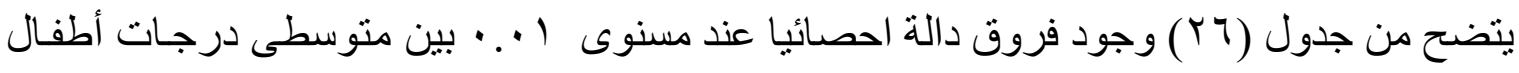

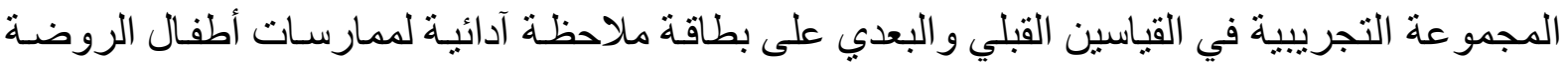

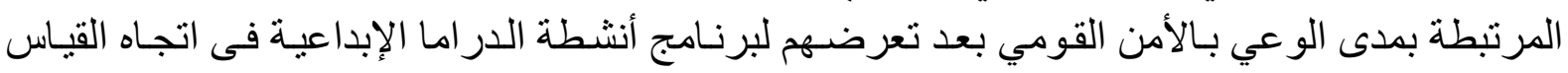
البعدى.

ويوضـح شـكل (ع) الفـروق بـين منتوســى درجـات أطفـال المجمو عــة التجريبيـة فـي القياسـين

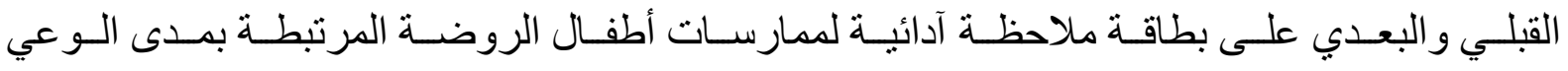
بالأمن القومي بعد تعرضهم لبرنامج أنشطة الدر اما الإبداعية. 


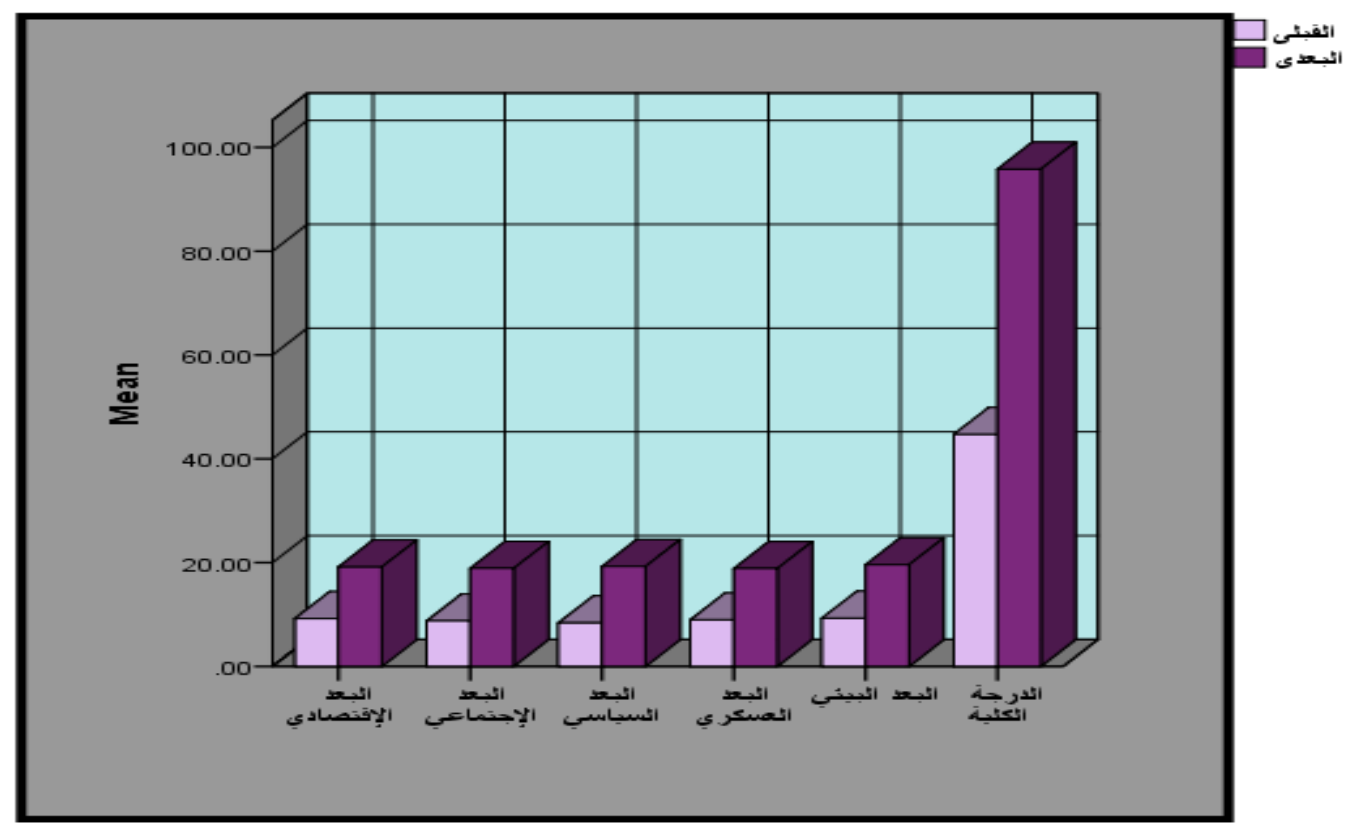

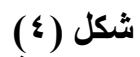

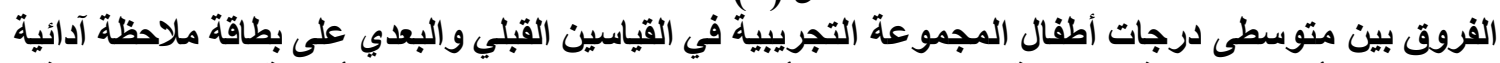

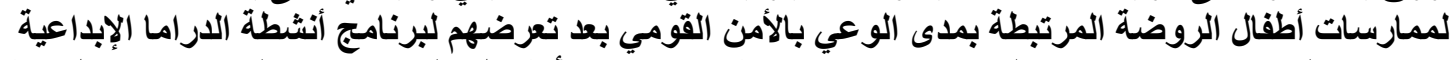

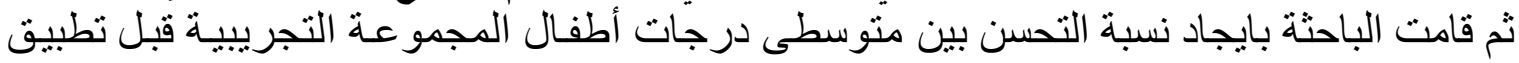

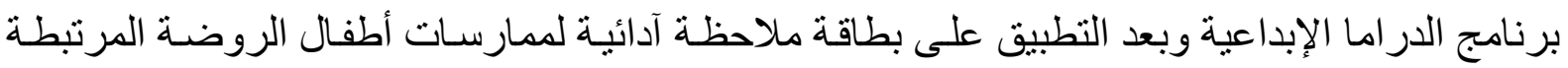
بمدى الوعي بالأمن القومي كما يتضح في جدول (YV) جدول (YV)

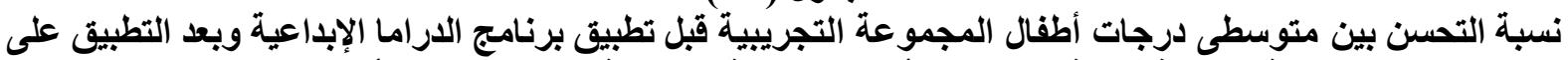

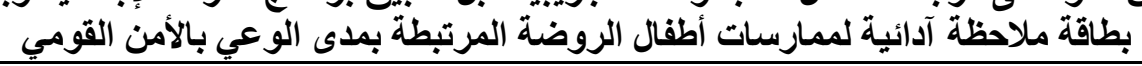

\begin{tabular}{|c|c|c|c|}
\hline نسبة التحسن & القياس القبلى & القياس البعدى & المتغيرات \\
\hline$\% 01 . \wedge r$ & $9 . r \mu$ & 19.17 & البعد الإقتصادى \\
\hline$\%$ \%ั. ช० & $1 . \vee 7$ & 11.9 & البعد الإجتماعي \\
\hline 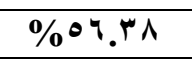 & $\Lambda . \xi$ & 19.49 & البعد السياسبي \\
\hline$\%$ or.\&q & 1.97 & $1 \wedge . \wedge 4$ & البعد العسكري \\
\hline$\%$ \% r.00 & 9.5 & 19.7 & البعد البيئي \\
\hline \%०r.rs & $\varepsilon \leqslant . V$ & 90.1 & الدرجة الكلية \\
\hline
\end{tabular}

تُحدد الباحثُة أسباب هذا التحسن لأطفال المجموعة التجريبيـة في مـا وفرتـه أنشطة الدر امـا الإبداعيـة

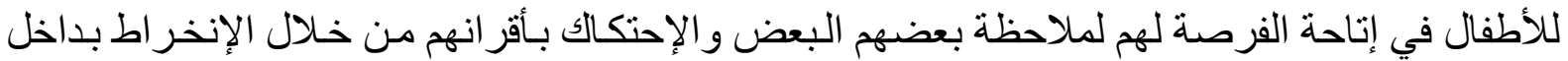

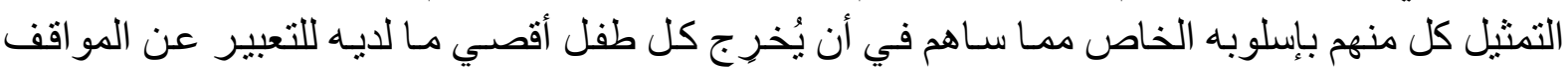

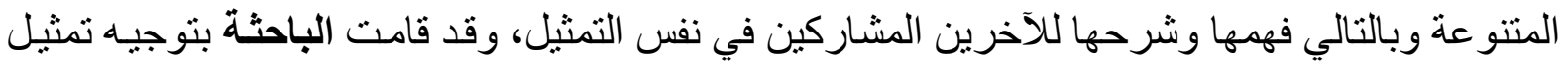
الأطفال في كل مرة شعرت فيها أن الأطفال خرجوا عن الهدف، وهذا يتفق مع ما أكدته دراسة اوزجير و و سيتسن (Özgür Ulubey \& Çetin Toraman, 2016)، مما ساعد الأطفال على تركيز عناصر

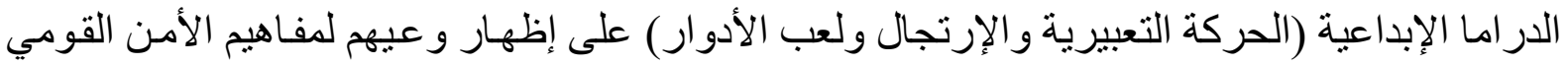

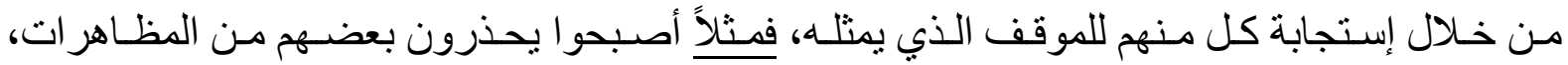

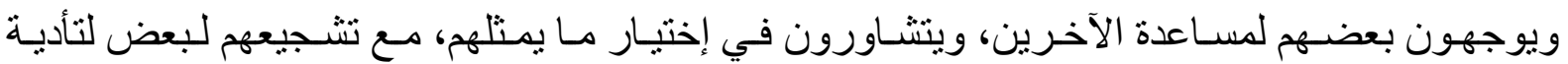

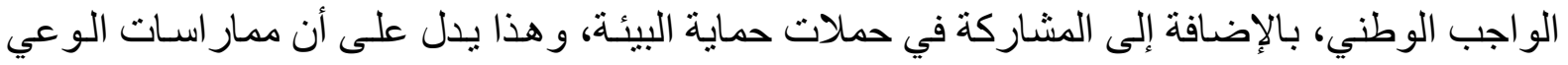


بالأمن القومي أصبح جزء من تكوينهم الثخصي و أصبحت ثُلاحظ على أقو الهم وسلوكياتهم بعكس أطفال

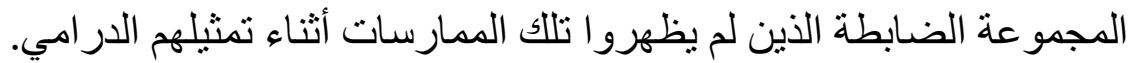

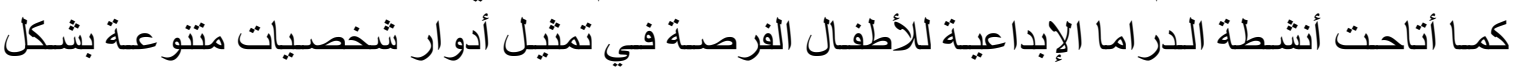

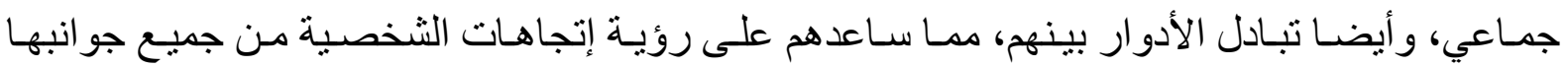

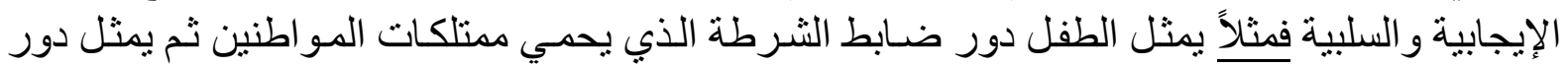

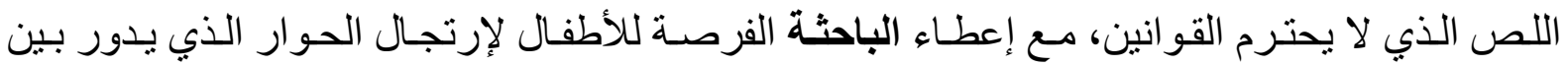

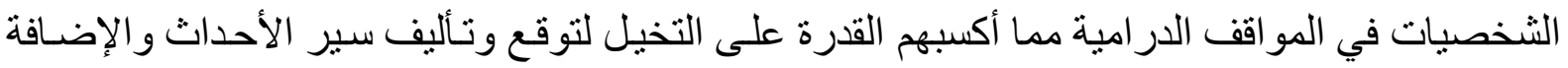

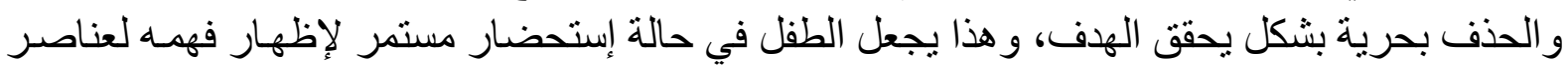

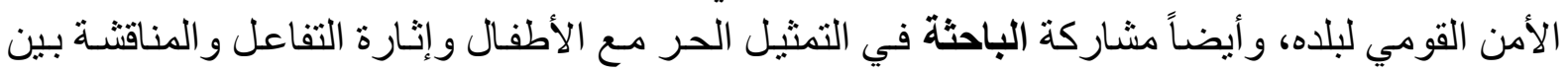

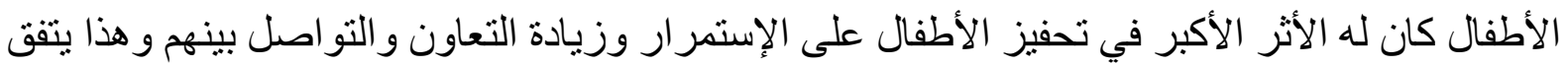

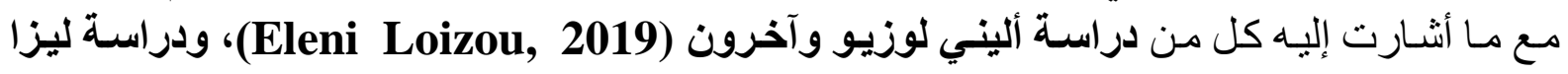

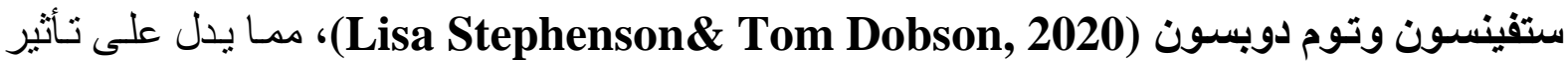

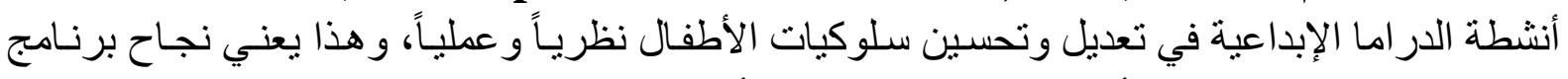

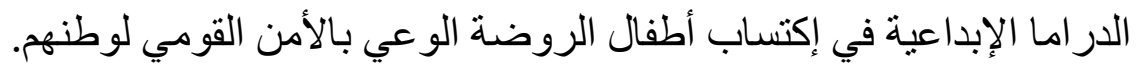
وتخلص الباحثة مما سبق إلى تحقى صحة الفرض الثراع الثالث.

\section{نتائج الفرض الرابع}

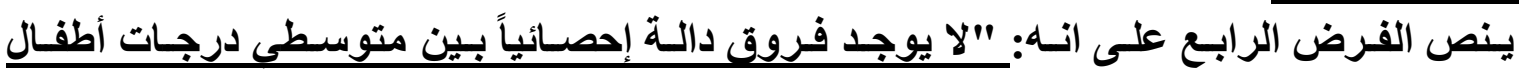

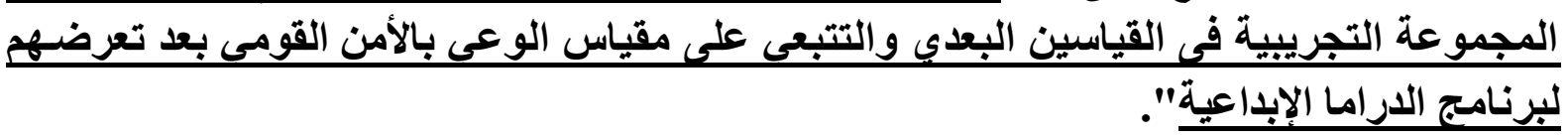

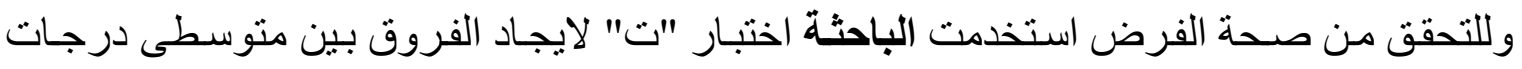

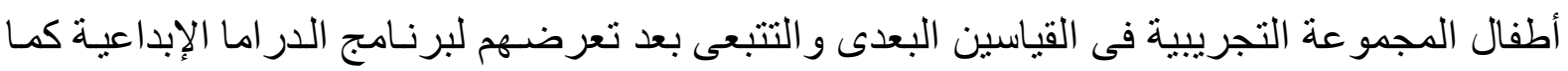

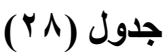

يتضح فى جدول (Y^)

الفروق بين متوسطى درجات أطفال المجموعة التجريبية بين القياسين البعدى والتتبعى بعد تعرضهم لبرنامج

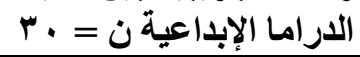

\begin{tabular}{|c|c|c|c|c|c|}
\hline \multirow[t]{2}{*}{ اتجاه الدلالة } & \multirow[t]{2}{*}{ مستوى الالالة } & \multirow[t]{2}{*}{$ت$} & \multicolumn{2}{|c|}{ القياسين البعدى و التين } & \multirow[t]{2}{*}{ المتغيرات } \\
\hline & & & مج ح ف & م ف & \\
\hline & غير دالة & $.7 \leq 1$ & $.10 \leq$ & $\because 1$ & البعد الإقتصادي \\
\hline- & غير دالة & $. . \leq 9 \leq$ & $.11 \% 0$ & $\because .79$ & البعد الإجتماعي \\
\hline & غير دالة &.$r r q$ &. .119 & $\cdot . r r$ & البعد السياسي \\
\hline - & غير دالة & .017 &. .194 & .1 & البعد العسكري \\
\hline - & غير دالة & 1 & .179 & .177 & البعد البيئي \\
\hline$\longrightarrow$ & غير دالة & $1.1 \cdot 1$ & $1 . r \cdot 1$ & $1 . \varepsilon r$ & الارجة الكلية \\
\hline
\end{tabular}

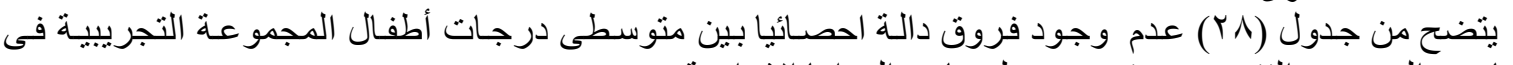

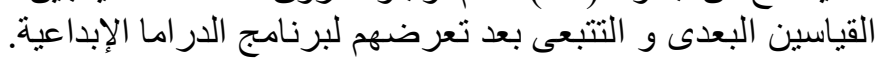


تُرجع الباحثة هذه النتيجة وبقاء أثر ها لفترة أطول بل وتحسن هذا الأثر إلى استمر ار فاعلية وتأثنير

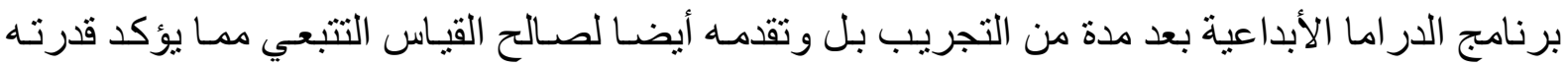

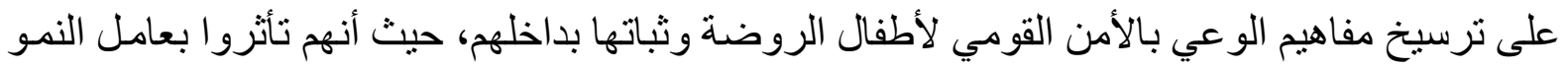

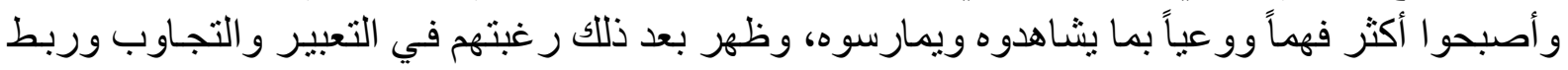

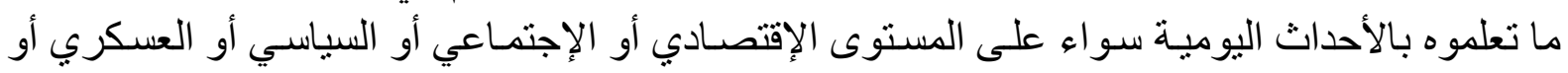

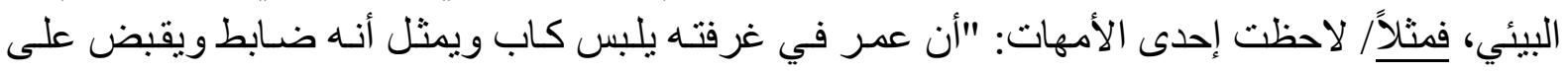

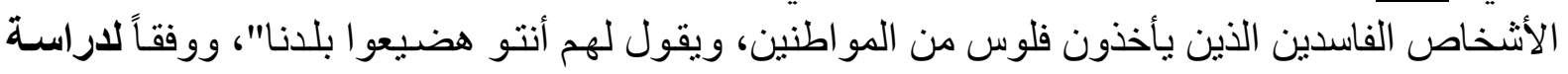
فيكتوريا براون (Victoria Brown, 2017) أن اللعب الإيهامي له دور كبير في تثبيت القيم الوطنية

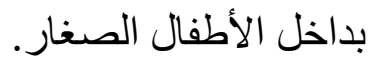

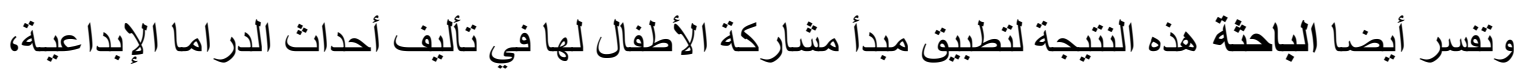

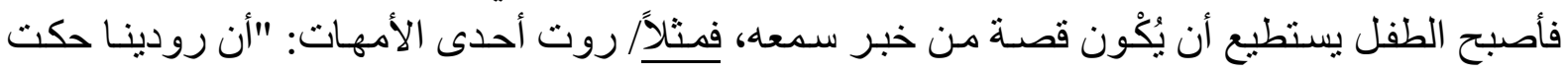

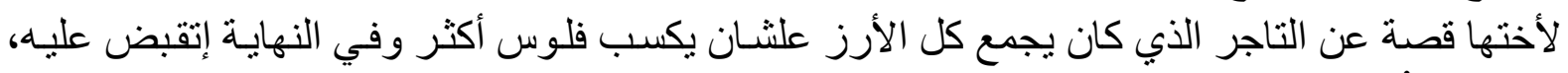

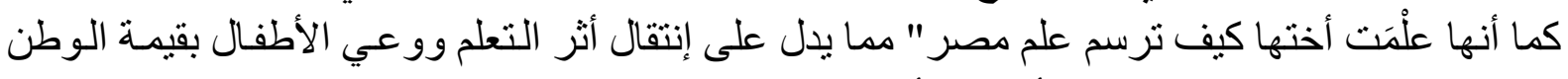

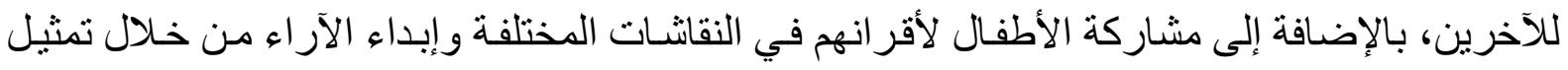

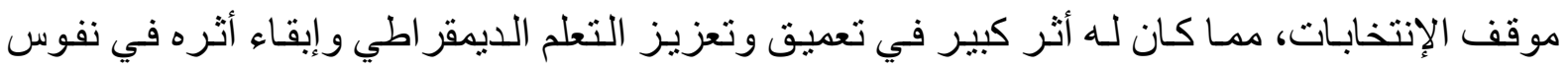

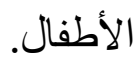

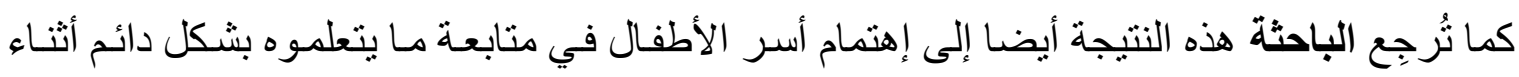

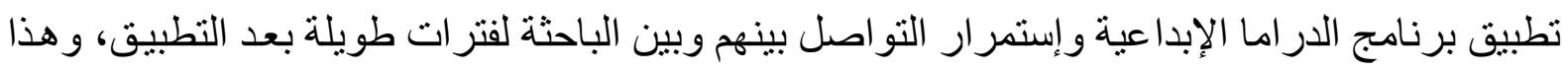

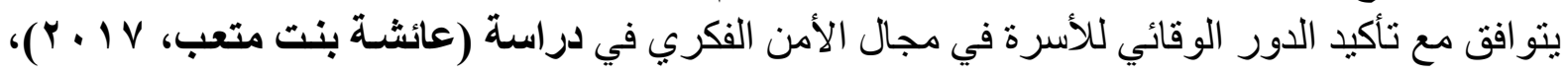

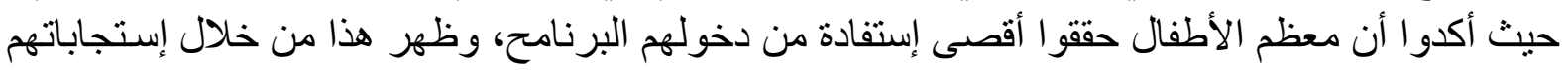

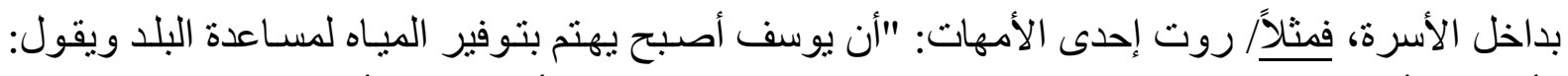

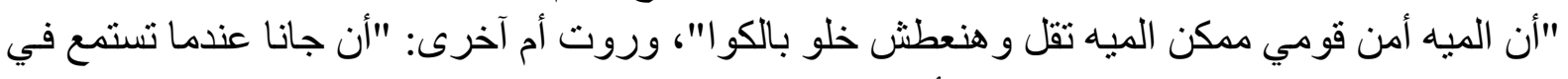

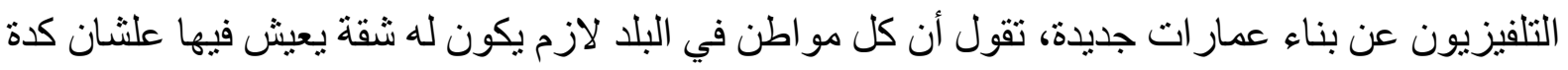

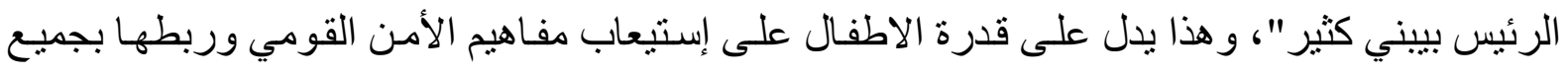
جوانب الوطن. وتخلص الباحثة مما سبق إلى تحقق صحة الفرض الرابع.

$$
\text { الخلاصة: }
$$

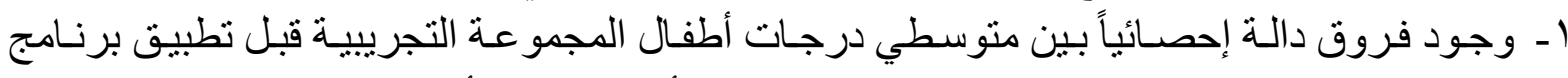

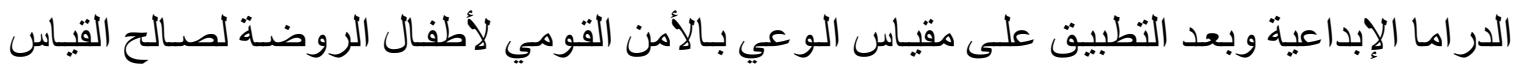

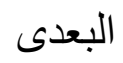

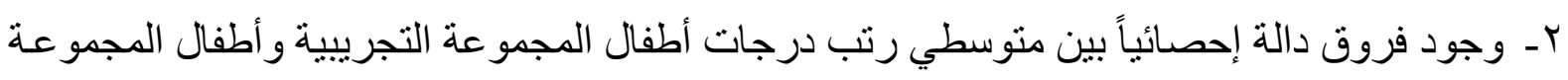

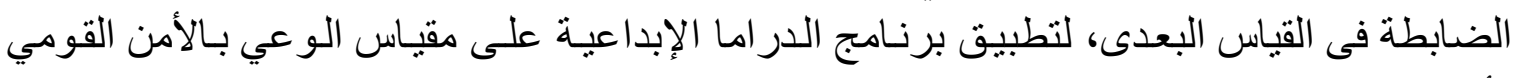
لأطفال الروضة لصالح المجمو عة التجريبية.. 
r- وجود فروق دالـة إحصائياً بين متوسطي درجات أطفال المجمو عـة التجريبية في القياسين القبلي

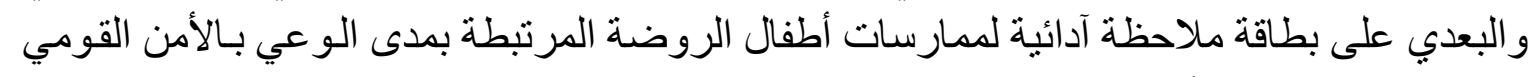

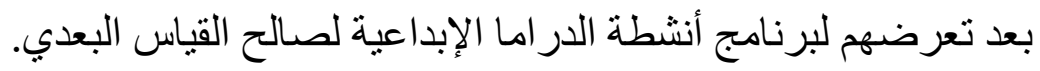

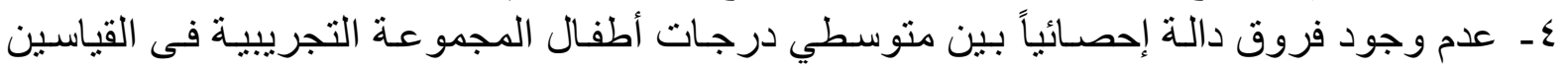

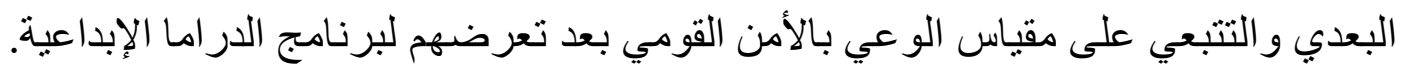

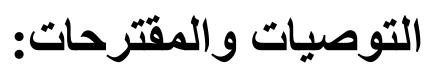

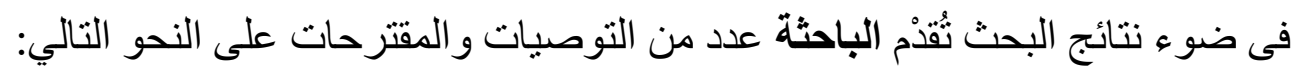

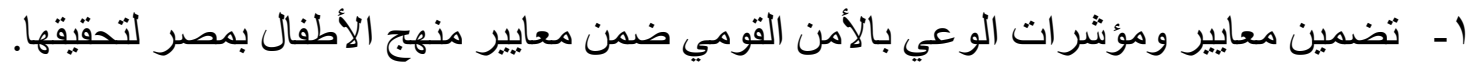

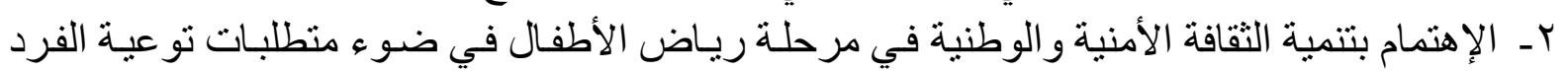

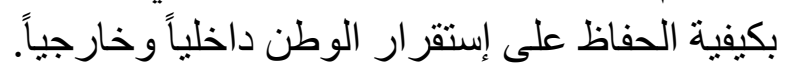

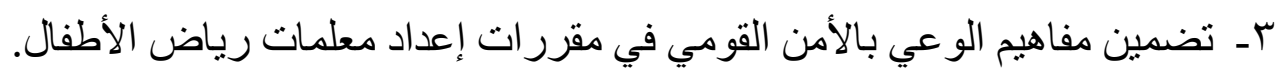

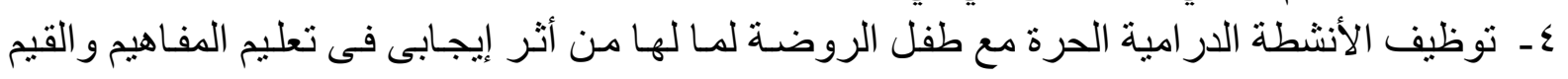
السياسية و الأمنية و الإجتماعية للأطفال. 


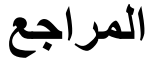

أولاً: المراجع العربية

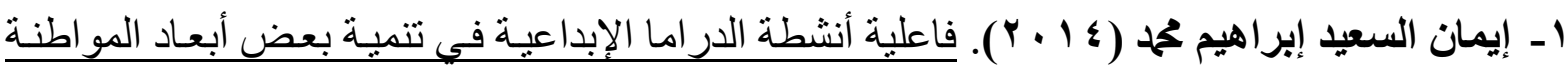
لادى طفل الروضة. ماجستير، كلية البنات للآداب و العلوم و التربية، جامعة عين شمس.

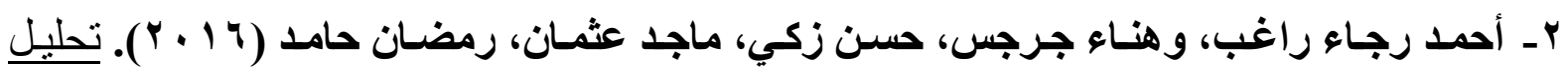
الوضع السكاني مصر. المجلس القومي للسكان: مركز بصيرة.

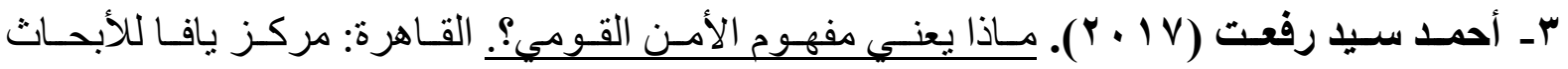
http://yafacenter.com/TopicDetails.aspx?TopicID والدراسات

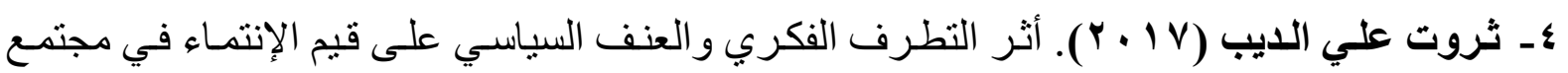

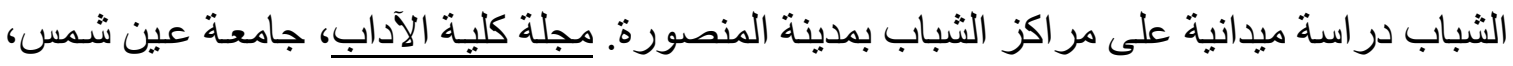
http//www.aafu.journals.ekb.eg. . (يناير - مارس)

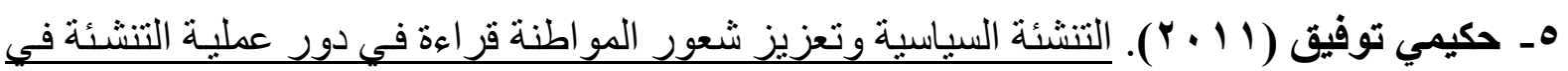
تقليص أثر التمايز الإجتماعي و العرقي. جامعة باجي مختار عنابة.

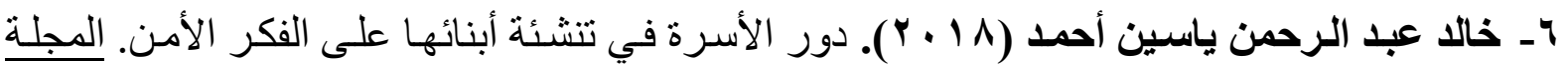
التربوية، كلية التربية، جامعة سو هاج.

V- ـانة بن صلال الربيعان، إبراهيم بن على مشرف الدخيل، منصور بن عبد الرحمن مناقش العسكر

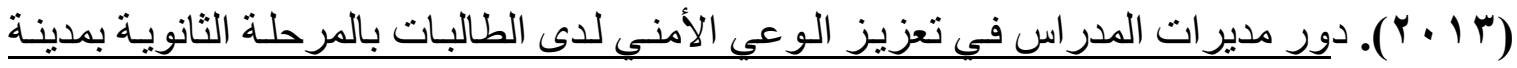

الرياض. ماجستير، كلية الدراسات العليا، قسم العلوم الإدارية، جامعة نايف العربية للعلوم الأمنية.

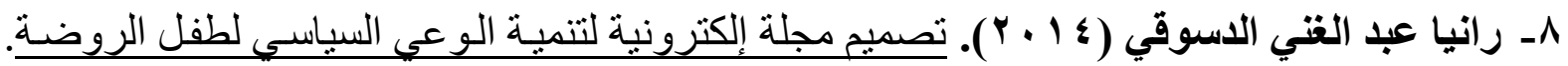
ماجستير. كلية التربية للطفولة المبكرة، جامعة القاهرة.

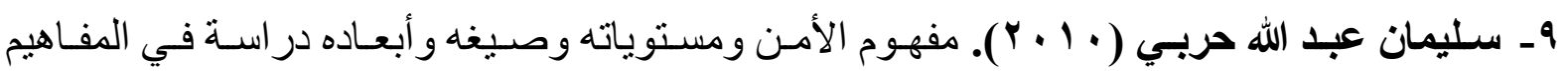
و الأطر. المجلة العربية للعلوم السياسية، مركز الدراسات و البحوث، الرياض، عدد (19 (1).

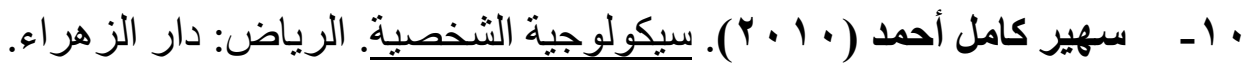

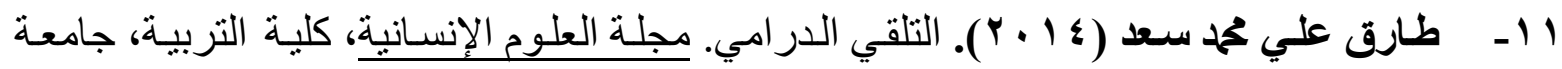
النيلين، ، r (10). (10)

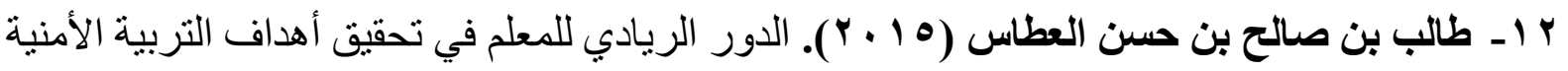

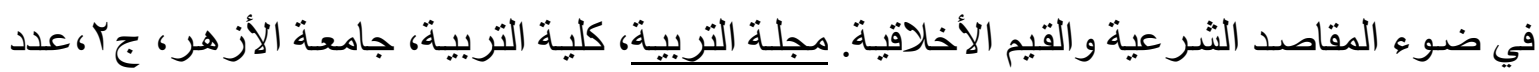




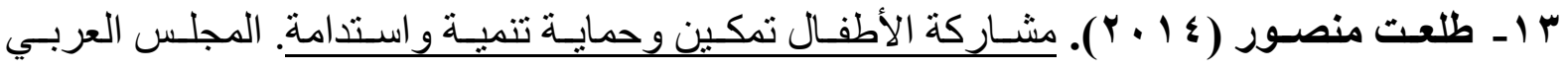
و الطفولة والتنمية، القاهرة: مطبعة النوبار.

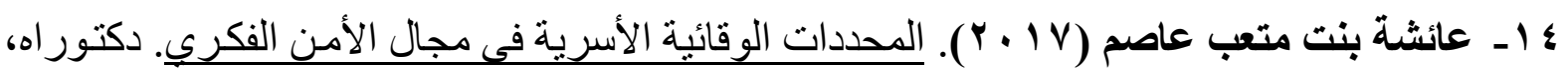
كلية العلوم الاجتماعية، جامعة نايف العربية للعلوم الأمنية.

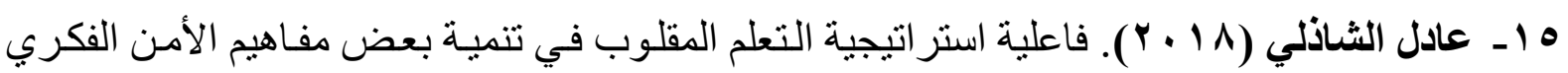

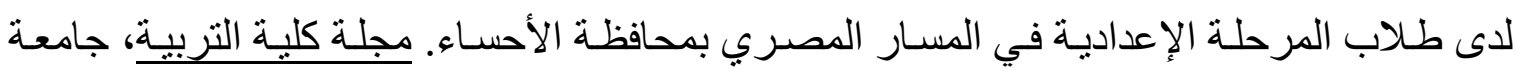

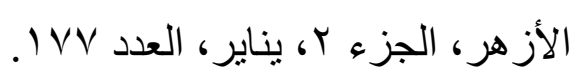

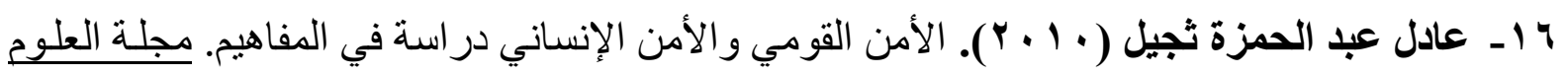

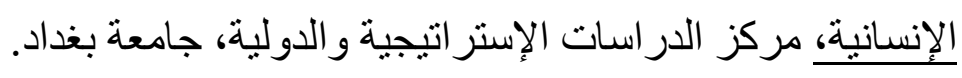

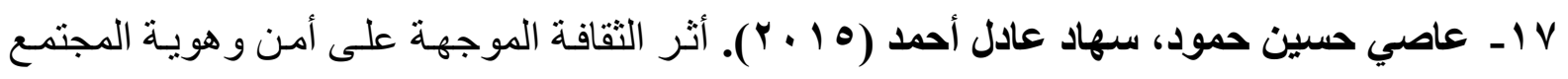

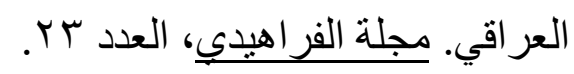

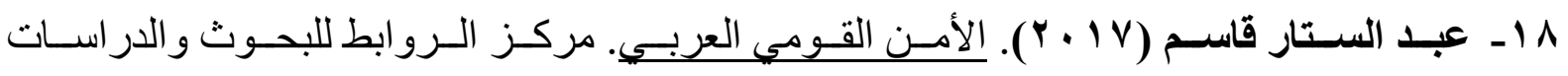
http://rawabetcenter.com/archives/587 الإستر اتيجية.

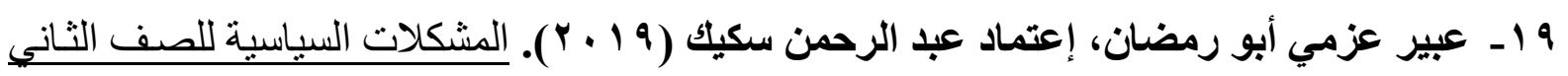

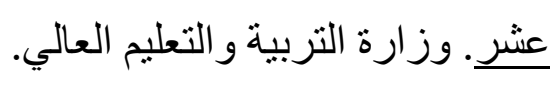

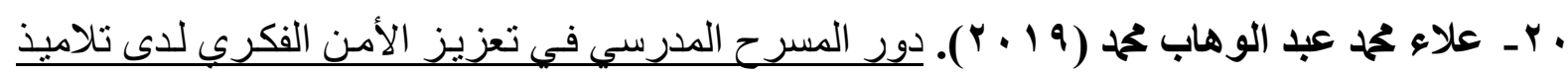

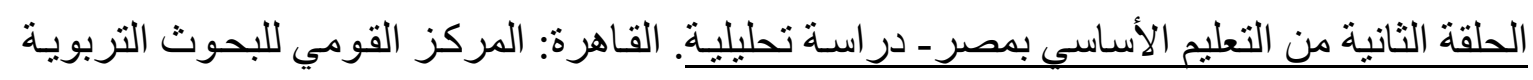

والتنمية.

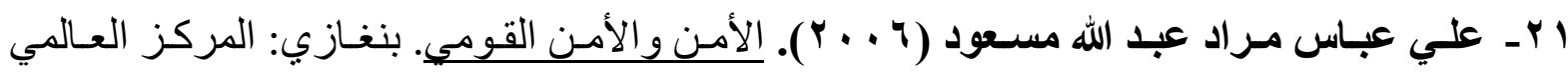
للار اسات و أبحاث الكتاب الأخضر.

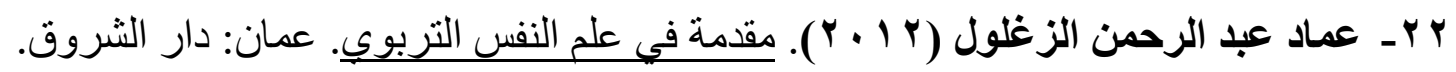

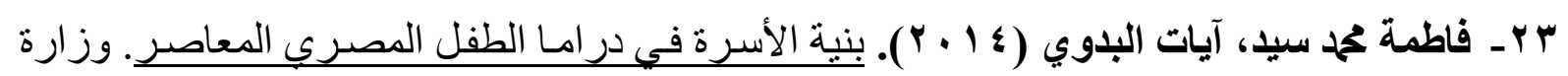
الثقافة، أكاديمية الفنون: المعهم العالي للنقد الفني.

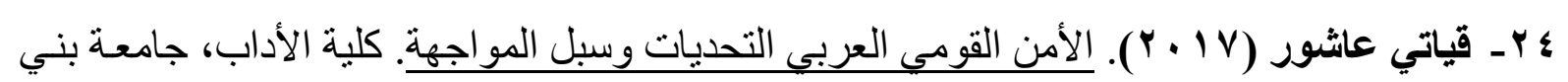

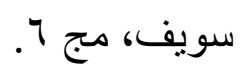

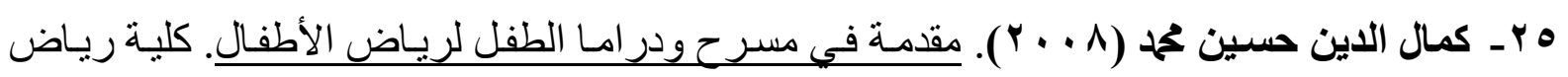
الأطفال: جامعة القاهرة.

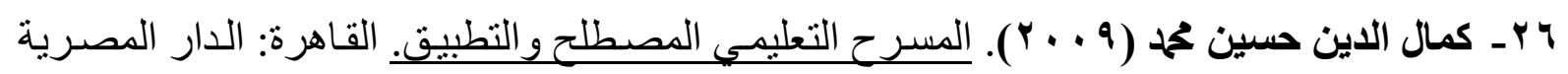




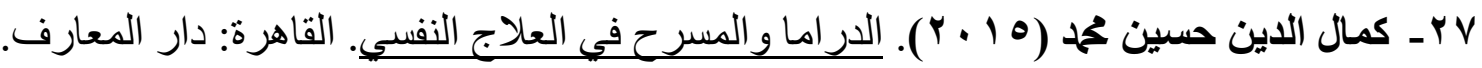

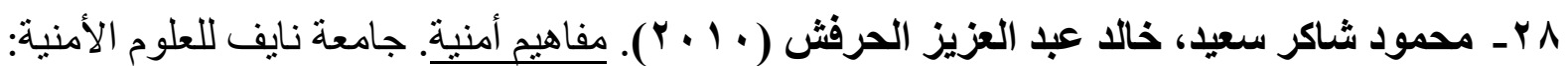

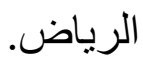

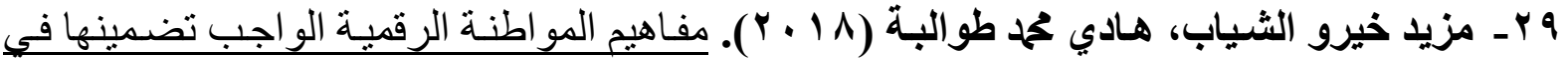
منـاهج التربيـة الوطنيـة و المدنيـة للمرحلـة الأساسية في الأردن مـن وجهـة نظـر معلمـي الدر اسـات

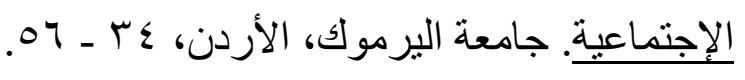

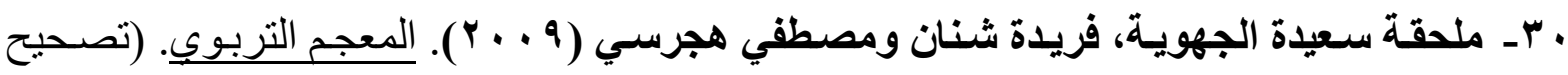

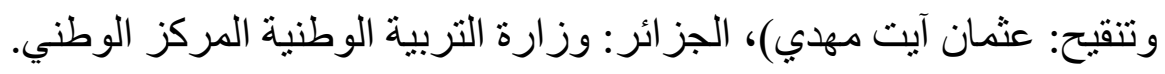

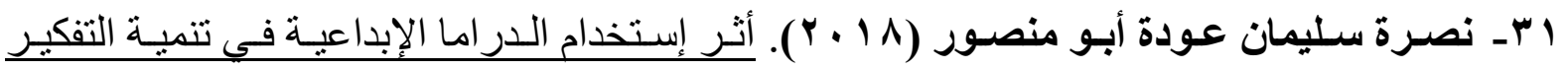
الإبتكاري و التحصيل في تـريس اللغـة العربيـة للدى طلبـة الصف الخـامس في العاصمة عمـان. ماجستير ، جامعة الثرق الأوسط، الأردن.

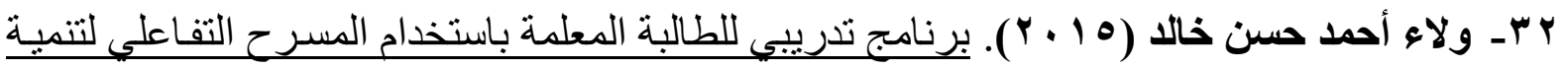

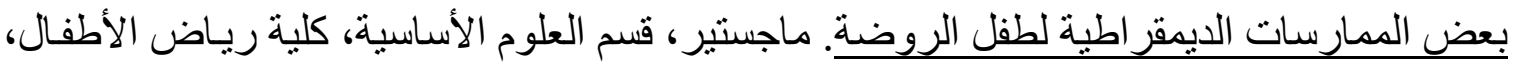

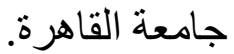

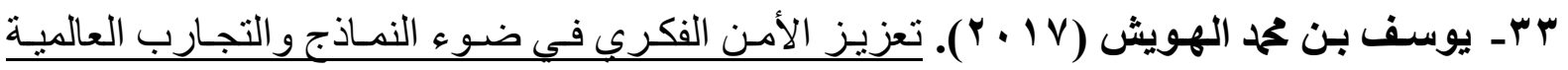

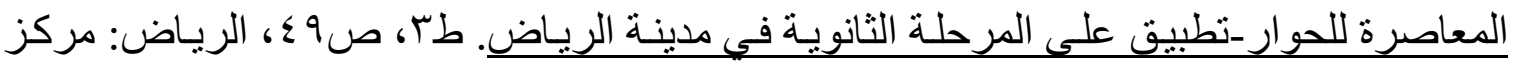
الملك عبد العزيز للحوار الوطني.

Foreign References ثانياً: المراجع الأجنبية 34- Akram Ghasempour \& Farhang Mozafar (2020). The Role of Creative Drama in Creativity Development of Children Aged 5 to 7 Years. International Journal for Modern Trends in Science and Technology, Vol. 06, Issue. 01, pp.01-11.

35- Cattanach, A. (2012). Drama for people with special need. A.C. black, London, p.30-32.

36- Daniel Ngboawaji (2018). Street Children and the Challenges of National security Evidence from Nigeria. Rivers State University of Education, Ignatius Ajuru University of Education. 
37- Eleni Loizou \& Anthia Michaelides \& Anna Georgiou (2019). Early Childhood Teacher Involvement in Children's Socio-Dramatic Play: Creative Drama as a Scaffolding Tool. Early Child Development and Care, v.189, n.4, pp.600-612, http://www.tandf.co.uk/journals.

38- Ervina Liasoi Lumandan (2018). Implementation of Creative Drama Activities in Three Selected Preschools. University of Malaya Kuala Lumpur :Cultural Center.

39- Gloria Quinones (2019). Developing a Drama Pedagogy for Toddler Education; Ridgway, Avis; Li, Liang. Journal of Early Childhood Research, Australia, v.17, n.2, pp.140-156.

40- Hakan Usakli (2018). Creative Drama Based Social Emotional Learning. Online Submission, Global Research in Higher Education Turkey, v.1, n.1, pp.1-16.

41- Moshood Babatunde Lawal (2020). Social Studies Teachers' Readiness to Teach the Security Education Theme in the Reviewed Edition of Nigeria's. Journal of International Social Studies, Nigeria Basic Education Curriculum, v. 10, 1. 2, pp. 154-176.

42- Nilgun Tosun \& Murat Altlnozb \& Emil Cayc \& Turan CinkilIcd \& Sevinc Gulsecene \& Tulay Yildirlmf (2020). A swot analysis to raise awareness about cyber security and proper use of social media. Istanbul sample International Journal of Curriculum and Instruction, v.12, Special Issue, pp. 271-294.

43- NSP (2017 - 2022). National Security Policy for change and well-being of the Filipino people. Republika Ng Pilipinas: Manila.

44- Pourrzaiyan, R. (2013), Psychological Evaluation of Children's Theater Article, Take a Look at Today's Child and Teen Theater, Functional drama, Center Publishing of the Intellectual Development of Children and Teenagers. 
45- Özgür Ulubey \& Çetin Toraman (2016). The Effect of Creative Drama Method on the Attitude towards Course: A Meta-Analysis Study Online Submission, Journal of Educational Sciences Research v6 n1 p87-115 Apr 2016

46- Ralph Doughty \& Linton Wells \& Theodore Hailes (2015). Innovative Learning: A Key to National Security. United States: Military education.

47- Rcubed (2017). Teaching Kids about Cybersecurity: it's never too early.

48-Sebastian van Baalen (2018). The Ethical Challenges of Fieldwork in the Digital Age Research Ethics. Thousand Oaks, CA 91320, v.14, n.4, http://sagepub.com.

49- Secil Horasan Dogan_\& Pasa Tevfik Cephe (2018). A Suggested Syllabus for Creative Drama Course in ELT. Journal of Language and Linguistic Studies, Turkey, v.14, n.2, pp.305-324.

50- Lisa Stephenson \&Tom Dobson (2020). Challenging Boundaries to Cross: Primary Teachers Exploring Drama Pedagogy for Creative Writing with Theatre Educators in the Landscape of Performativity. Professional Development in Education, v46 n2 p245-255 2020

51- Tufan Aytaci \& Mustafa Erdem (2019). Examining High School Students' Safe Computer And Internet USAGE Awareness European. Journal of Education Studies, v.6, Issue.1,doi: 10.5281/zenodo.2652846, ISSN: 2501 - 1111, www.oapub.org/edu.

52- Tunde Szecsi (2012). Teaching Strategies: Creative Drama in Preschool Curriculum: Teaching Strategies Implemented in Hungary._Journal Childhood Education, V. 85, Issue. 2, pp. 120-124.

53- Victoria Brown (2017). Drama as a Valuable Learning Medium in Early Childhood Arts Education Policy Review. Taylor \& Francis, v.118, n.3 pp.164-171, http://www.tandf.co.uk/journals.

54- U.S. Department of Education Document (2006). Teaching Language for National Security and American Competitiveness. U.S. 
55- Victoria Brown (2017). Drama as a Valuable Learning Medium in Early Childhood. Arts Education Policy Review Taylor \& Francis, v118 n3 p164171.

56- Yu-Chu Yeh (2008). Research for Mind, Brain \& Learning. National Chengchi University; Me-Lin Li, Teacher, Shangkuan Elementary School, National Science Council (NSC93-2413-H-004-015) and the Action Research of Creative Teachers from the Ministry of Education, Institute of Teacher Education, Taiwan, v.42, N.2, Second Quarter, ycyeh@ nccu.edu.tw.

57-Zaid Al-Edwan Suleiman (2016). The Security Education Concepts in the Textbooks of the National and Civic Education of the Primary Stage in Jordan An Analytical Study International Education Studies. Canadian Center of Science and Education. V.9, n.9, pp.146-156, http://www.ccsenet.org/journal/index.php/es. 